


\section{U.S. Department of the Interior \\ U.S. Geological Survey}

Ground-Water Resources along the Little Bighorn River,

Crow Indian Reservation, Montana

By L.K. Tuck

Water-Resources Investigations Report 03-4052

Helena, Montana

June 2003

In cooperation with the

BUREAU OF INDIAN AFFAIRS 
U.S. Department of the Interior

GALE A. NORTON, Secretary

\section{U.S. Geological Survey}

Charles G. Groat, Director

For additional information write to:

District Chief

U.S. Geological Survey

3162 Bozeman Avenue

Helena, MT 59601-6456

Copies of this report may be purchased from:

U.S. Geological Survey

Branch of Information Services

Box 25286

Denver, CO 80225-0286 


\section{CONTENTS}

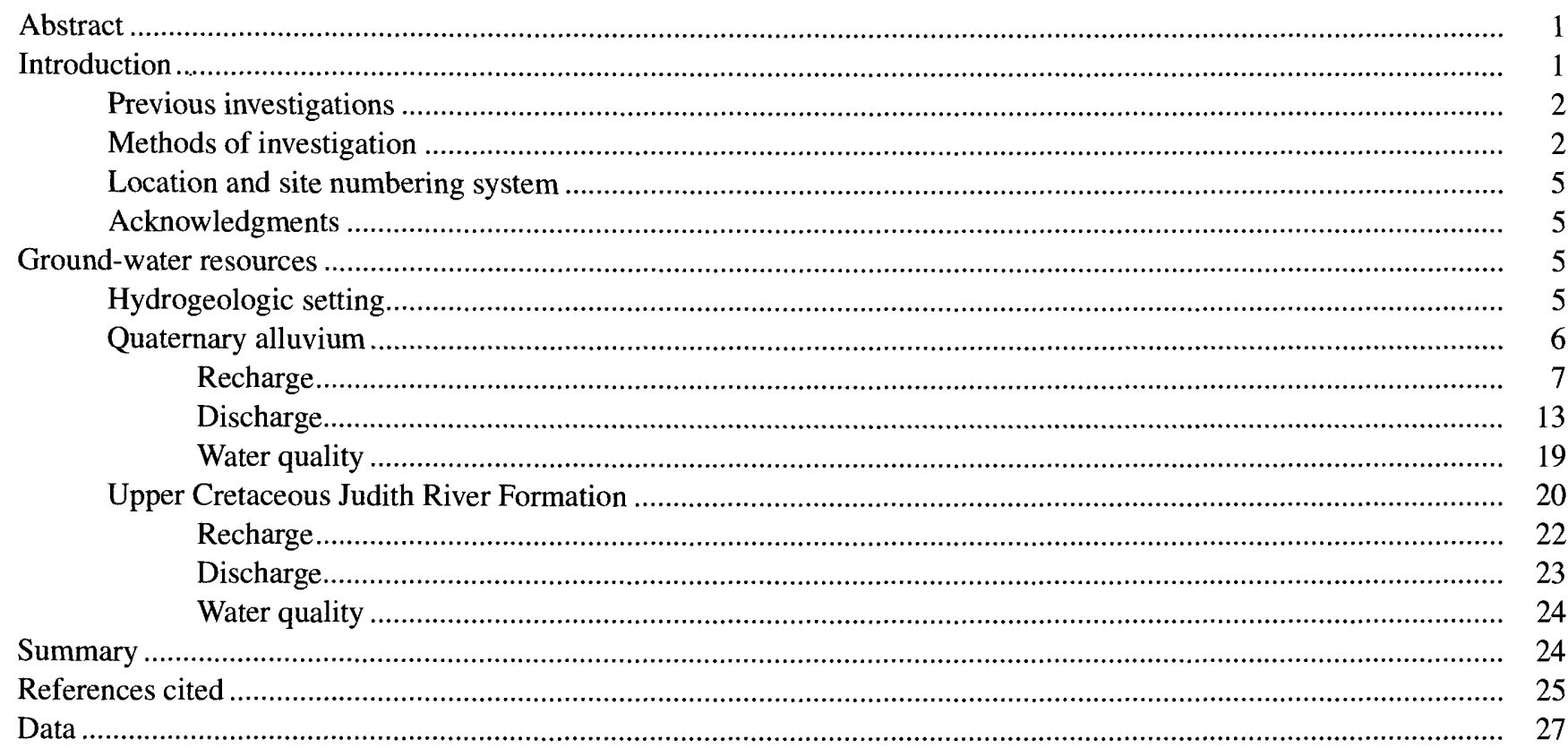

\section{ILLUSTRATIONS}

Plate 1. Map showing selected hydrogeologic characteristics of aquifers along the Little Bighorn

River and adjacent areas, Montana

Figure 1. Map showing location of the study area in Montana.........................................................................

2. Diagram showing numbering system for ground-water sites ............................................................ 6

3-8. Graphs showing:

3. Mean monthly precipitation for the 1961-90 period of record and monthly precipitation totals for the study period at Hardin and near Wyola, Montana

4. Hydrographs of water levels in selected wells along the Little Bighorn River and adjacent areas, Montana

5. Seasonal variation in water levels in wells completed in Quaternary alluvium and comparison to streamflow of the Little Bighorn River, Montana

6. Schematic diagram showing synoptic-streamflow measurement sites along the Little Bighorn River, Montana.

7. Synoptic-streamflow measurements and specific conductance of the Little Bighorn River, Montana, October 25, 1994

8. Seasonal variation in water levels in wells completed in Quaternary alluvium and the Upper Cretaceous Judith River Formation downgradient from the Reno Canal, Montana

9. Boxplots showing distribution of concentrations for selected chemical constituents in water from Quaternary alluvium and the Upper Cretaceous Judith River Formation along the Little Bighorn River and adjacent areas, Montana

\section{TABLES}

Table 1. Estimates of recharge and discharge components for Quaternary alluvium and the Upper Cretaceous Judith River Formation along the Little Bighorn River and adjacent areas, Montana

2. Gains in streamflow calculated from concurrent streamflow-gage records during base flow for the Little Bighorn River, Pass Creek, and Lodge Grass Creek, Montana 


\section{TABLES--continued}

Table 3. Synoptic-streamflow and specific-conductance measurements along the Little Bighorn River, Montana, October 25, 1994

4. Hydrologic and field water-quality data for ground-water sites along the Little Bighorn River and adjacent areas, Montana..

5. Water-level data from selected wells along the Little Bighorn River and adjacent areas, Montana

6. Hydrogeologic data and estimates of transmissivity at selected wells completed in the Quaternary alluvium and the Upper Cretaceous Judith River Formation along the Little Bighorn River and adjacent areas, Montana

7. Physical properties and major-ion, trace element, and radon concentrations in water from selected wells along the Little Bighorn River and adjacent areas, Montana 


\section{CONVERSION FACTORS, DATUM, ABBREVIATED WATER-QUALITY UNITS, AND ACRONYMS}

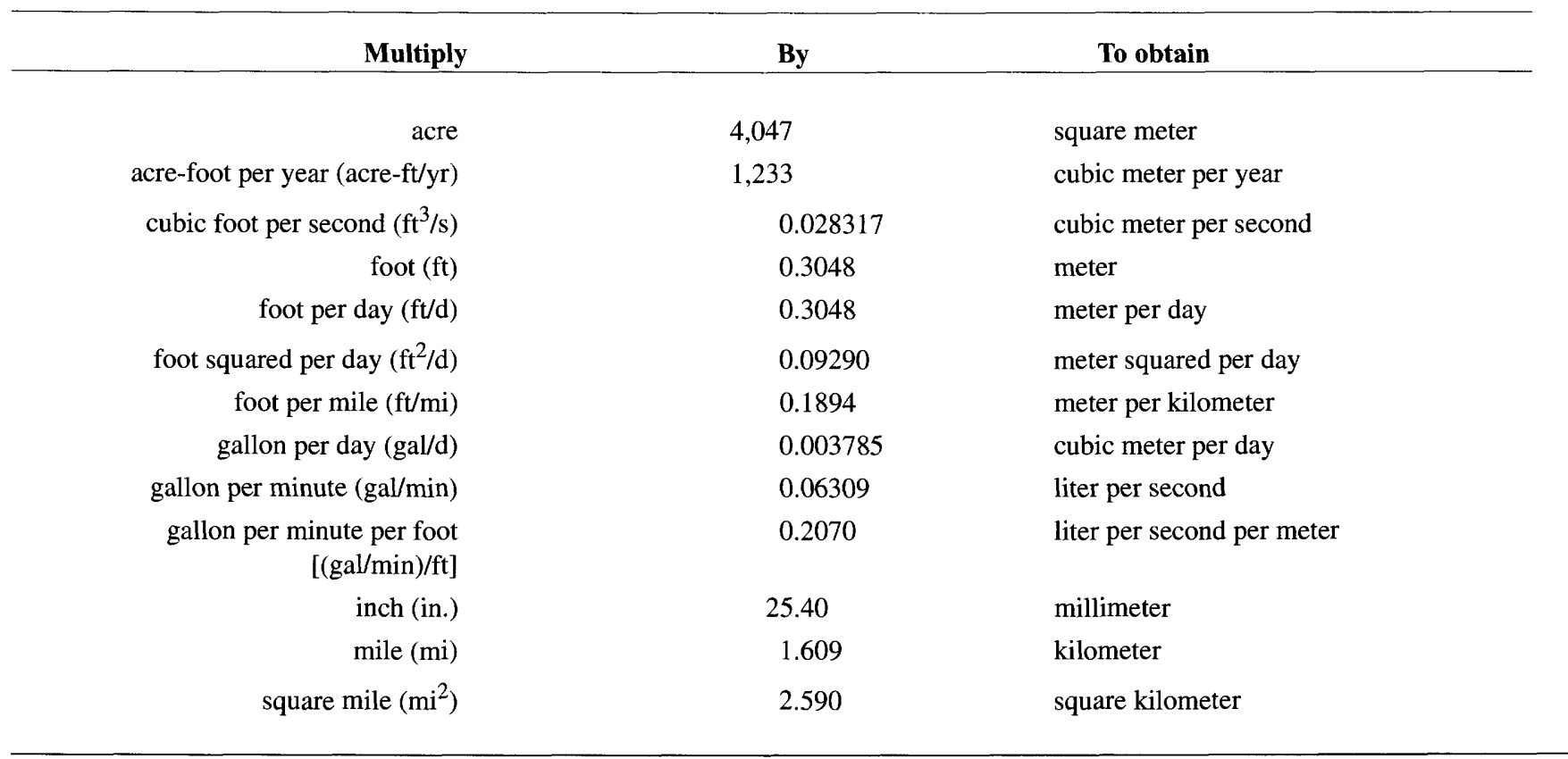

Degree Celsius $\left({ }^{\circ} \mathrm{C}\right)$ may be converted to degree Fahrenheit $\left({ }^{\circ} \mathrm{F}\right)$ by using the following equation:

$$
{ }^{\circ} \mathrm{F}=9 / 5\left({ }^{\circ} \mathrm{C}\right)+32 .
$$

Vertical coordinate information is referenced to the National Geodetic Vertical Datum of 1929 (NGVD 29). Horizontal coordinate information is referenced to the North American Datum of 1927 (NAD 27), unless otherwise noted.

Water year: The 12-month period October 1 through September 30. It is designated by the calendar year in which it ends.

Abbreviated water-quality units used in this report:

$\begin{array}{ll}\mu \mathrm{S} / \mathrm{cm} & \text { microsiemens per centimeter at } 25 \text { degrees Celsius } \\ \mu \mathrm{g} / \mathrm{L} & \text { micrograms per liter } \\ \mathrm{mg} / \mathrm{L} & \text { milligrams per liter } \\ \mathrm{pCi} / \mathrm{L} & \text { picocuries per liter }\end{array}$

Acronyms used in this report:

BIA

CEPP

EPA

GIS

IHS

MCL

NWIS

SDWR

USGS
Bureau of Indian Affairs, U.S. Department of the Interior

Crow Environmental Protection Program

U.S. Environmental Protection Agency

Geographic Information System

Indian Health Service

U.S. Environmental Protection Agency Maximum Contaminant Level

National Water Information System

U.S. Environmental Protection Agency Secondary Drinking-Water Regulation

U.S. Geological Survey 



\title{
Ground-Water Resources along the Little Bighorn River, Crow Indian Reservation, Montana
}

\author{
by L.K. Tuck
}

\section{ABSTRACT}

This report describes the general geology and the water resources of Quaternary alluvium and the Upper Cretaceous Judith River Formation along the Little Bighorn River within the Crow Indian Reservation of southeastern Montana. Data were collected and compiled for 193 ground-water sites and 27 surface-water sites.

Quaternary alluvium underlies an area of about 94 square miles located primarily along the Little Bighorn River and is composed of unconsolidated gravel, sand, silt, and clay. Thickness of the probable waterbearing zone within the alluvium ranges from 2 to 39 feet, with a median of 9 feet. The specific capacity of wells completed in Quaternary alluvium ranged from 0.31 to 30 gallons per minute per foot [( $\mathrm{gal} / \mathrm{min}) / \mathrm{ft}$ ], transmissivity estimates ranged from 230 to 6,900 feet squared per day $\left(\mathrm{ft}^{2} / \mathrm{d}\right)$, and well yields ranged from 4 to 50 gallons per minute ( $\mathrm{gal} / \mathrm{min})$. Low specific capacity, transmissivity, and well yield are typical of alluvium deposited by rivers having a small carrying and sorting capacity, which results in deposits containing substantial quantities of fine-grained material. Discontinuous or poorly connected lenses of coarsergrained material are also typical.

Recharge to Quaternary alluvium is by infiltration and subsequent percolation of precipitation, canal leakage, excess applied irrigation water, bank storage, and by subsurface inflow from alluvium in small ephemeral tributaries adjacent to the Little Bighorn valley and from the underlying Judith River Formation. Discharge from Quaternary alluvium is primarily through evapotranspiration, withdrawals from wells, flow to irrigation drains, and subsurface outflow to the Little Bighorn River. Ground water was estimated to contribute about 15 to 18 percent of the annual daily mean streamflow (in water year 1995) of the Little Bighorn River near Hardin.

Water in Quaternary alluvium generally had high concentrations of dissolved calcium, magnesium, sodium, bicarbonate, sulfate, chloride, and iron. Dissolved-solids concentrations ranged from 264 to 4,770 milligrams per liter $(\mathrm{mg} / \mathrm{L})$, with a median of 1,450 $\mathrm{mg} / \mathrm{L}$. The chemical quality of water from alluvium varied and some water can pose a health risk for domestic use.

The Upper Cretaceous Judith River Formation contains an unnamed upper member composed of about 700 feet of sandstone interbedded with sandy shale and shale and a lower member, the Parkman Sandstone Member, which is composed of as much as 350 feet of massive sandstone and sandy shale. Specific capacity of wells completed in the Judith River Formation ranged from 0.06 to 7.4 (gal/min)/ft, transmissivity estimates from specific-capacity tests ranged from 39 to $780 \mathrm{ft}^{2} / \mathrm{d}$, and well yields ranged from 5 to $74 \mathrm{gal} / \mathrm{min}$. Low specific capacity, transmissivity, and well yield are typical of the upper part of the Judith River Formation where interbedded shale and finegrained sandstone can be lenticularly bedded and laterally discontinuous. The lower part of the Judith River Formation (Parkman Sandstone Member) is a finegrained sandstone that is massive locally, but also is not uniform throughout the study area.

Recharge to the Judith River Formation is by infiltration and subsequent percolation of precipitation, infiltration of streamflow across outcrops, canal leakage, bank storage, and by subsurface inflow from Quaternary high-terrace deposits. Discharge from the Judith River Formation is primarily through upward subsurface outflow to Quaternary alluvium and the Little Bighorn River, withdrawals from wells, and evapotranspiration.

The major-ion composition of most water in the Judith River Formation was predominated by sodium, bicarbonate, and sulfate. Dissolved-solids concentrations in water from the Judith River Formation ranged from 352 to $1,910 \mathrm{mg} / \mathrm{L}$, with a median of $1,000 \mathrm{mg} / \mathrm{L}$. The chemical quality of water from the Judith River Formation varied and is probably suitable for most domestic use.

\section{INTRODUCTION}

The Little Bighorn River drains about $1,300 \mathrm{mi}^{2}$ of mountains, foothills and valleys. Some of the drainage area is in the Bighorn Mountains of Wyoming, but 
about $1,100 \mathrm{mi}^{2}$ of the drainage area is located on the Crow Indian Reservation in southeastern Montana (fig. 1). On the Reservation, the Little Bighorn River flows north for a distance of about $80 \mathrm{mi}$ through foothills and the alluvial valley. Because of its meandering, the distance along the main river channel (river miles) is about $120 \mathrm{mi}$. Perennial tributaries to the Little Bighorn River include Lodge Grass and Pass Creeks; large ephemeral tributaries include Owl and Reno Creeks.

The principal land uses of the area are agricultural, including irrigated alfalfa, pasture grass, corn, and sugar beet production along the irrigated valley. Grass-covered rangeland for cattle production is interspersed with nonirrigated farmland along the higher terraces and foothills.

The Little Bighorn River and Lodge Grass and Pass Creeks are important sources of water for irrigation, although most water used for irrigation is diverted from the Little Bighorn River. Terraces along the river and adjacent areas are irrigated by this water. Lodge Grass Storage Reservoir, located near Lodge Grass Creek about 30 river miles upstream from its confluence with the Little Bighorn River, stores water diverted from Lodge Grass Creek to supply the Lodge Grass Canal No. 1 (pl. 1). Water from the Little Bighorn River also is used for municipal supply for the Town of Crow Agency.

Beyond the municipal boundaries of Crow Agency, water from Quaternary alluvium and the Upper Cretaceous Judith River Formation is the primary source for domestic and stock supplies. Shallow ground water (less than about $100 \mathrm{ft}$ below land surface) generally is not available for domestic and stock use in areas where the alluvium or the Judith River Formation do not exist. Quaternary alluvium along the Little Bighorn River underlies flood plains and adjacent terraces and consists of unconsolidated gravel, sand, silt, and clay. The Judith River Formation crops out generally along or west of the Little Bighorn River and Pass Creek and underlies alluvium along most of the Little Bighorn River valley.

Information about the ground-water resources along the Little Bighorn River in Montana was limited. A better understanding of aquifer hydraulic characteristics, potentiometric surface, water quality, and interactions between the aquifers and the Little Bighorn River and other hydrogeologic units in the study area was needed to help address water-rights issues and water-quality concerns, and provide a better basis for water-management decisions. Consequently, the U.S.
Geological Survey (USGS), in cooperation with the Bureau of Indian Affairs (BIA), conducted a study to obtain additional information to characterize the ground-water resources along the Little Bighorn River.

This report describes the general geology and the water resources of the Quaternary alluvium and the Upper Cretaceous Judith River Formation along the Little Bighorn River within the Crow Indian Reservation of southeastern Montana. The report contains hydrogeologic maps of the area and describes major aquifers along the Little Bighorn River, including their water-yielding characteristics and water quality.

Data were collected and compiled for 193 ground-water and 27 surface-water sites. Availability and quality of ground water were determined from inventory, periodic water-level measurements, and sampling of ground water. Data from the Indian Health Service (IHS) Hospital, Crow-Northern Cheyenne Public Health Service, also were compiled to determine aquifer geometry, characteristics, and water quality. Data from five streamflow-gaging stations were compiled and used to evaluate interactions between the aquifers and the Little Bighorn River.

\section{Previous Investigations}

The first investigation in the study area conducted by Thom and others (1935) was a reconnaissance principally of geography, drainage, and geology but included information about the water resources of the area. Moulder and others (1960) conducted a reconnaissance in the early 1950 s of ground water along the northern part of the Little Bighorn River from near Lodge Grass to Hardin. The geology and groundwater resources were investigated, but the study focused primarily on factors affecting drainage of irrigated and irrigable land, and effects of irrigation on ground water. Richards (1955), Bergantino (1980), and Kanizay (1986a, b) mapped the geology or compiled geologic information in the study area.

\section{Methods of Investigation}

Hydrogeologic data were collected during 199495 by inventorying 192 existing wells and one spring. Data included well location, altitude of land surface, use of water, depth of well, diameter of well casing, static-water level, and well yield. Onsite water-quality 


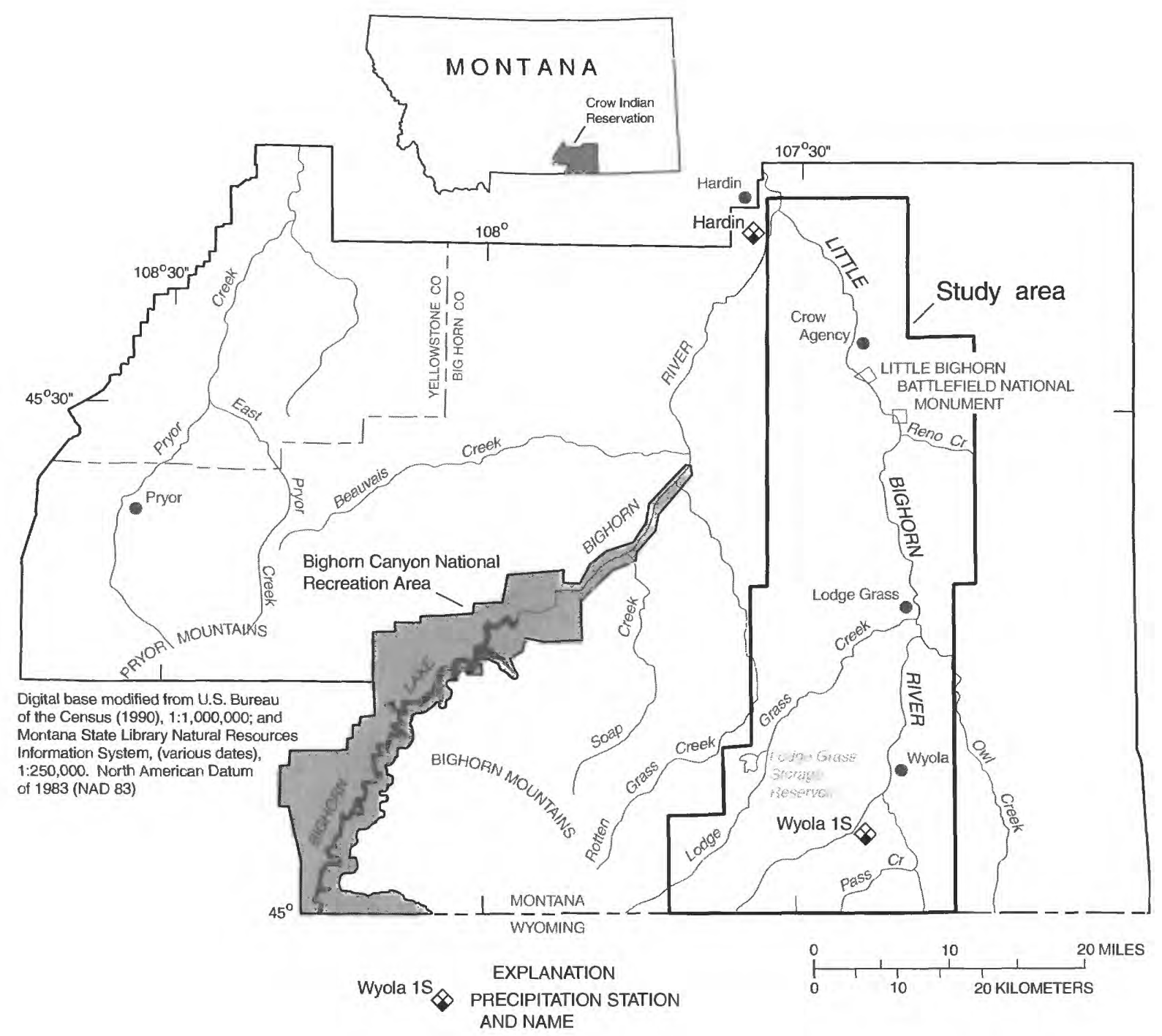

Figure 1. Location of the study area in Montana.

properties determined during the well inventory included specific conductance, $\mathrm{pH}$, and water temperature (table 4 at back of report). In addition, drillers' logs were used when available to obtain information about well completion, specific capacity, aquifer composition and geometry, and whether aquifers were confined or unconfined. Selected wells were measured periodically to document water-level changes and evaluate the interactions between the aquifers and the Little Bighorn River and irrigation canals (table 5 at back of report).
Transmissivity was estimated from specificcapacity tests using data collected during the well inventory or data from drillers' logs (table 6 at back of report). These estimates were derived from a modified Theis equation that estimates transmissivity from specific-capacity tests for confined conditions (Heath, 1983, p. 60-61):

$$
T=\frac{W(u)}{4 \pi} \times \frac{Q}{s}
$$

where: 


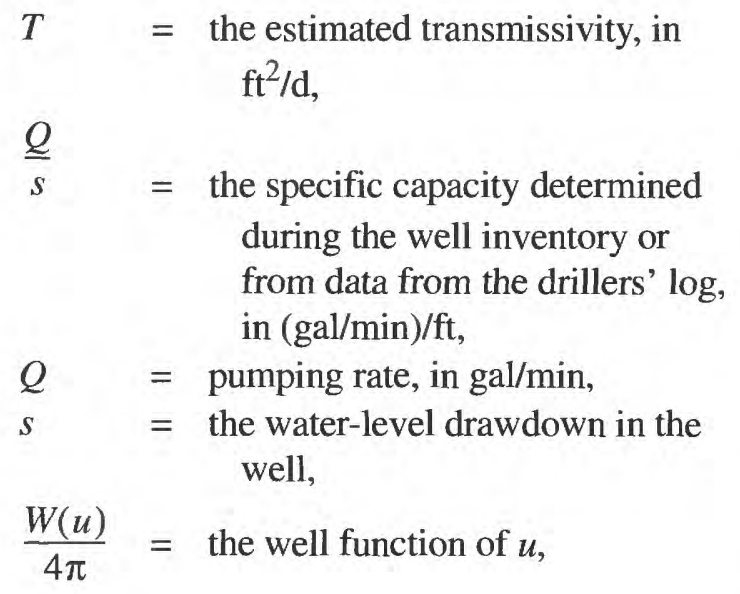

where:

$$
u=\frac{r^{2} S}{4 T t}
$$

where:

$$
\begin{aligned}
& r \quad=\text { the radius of the well (in } \mathrm{ft} \text { ), } \\
& S \quad=\text { based on a previously determined } \\
& \text { storage coefficient (dimension- } \\
& \text { less) } \\
& T \quad=\text { based on a previously determined } \\
& \text { transmissivity (in } \mathrm{ft}^{2} / \mathrm{d} \text { ), and } \\
& t=\text { the length of the pumping period } \\
& \text { (in hours). }
\end{aligned}
$$

Heath (1983, p. 35) presented a table of values of $W(u)$ for values of $1 / u$ which allowed the value of $W(u)$ to be substituted into equation 1 . An average storage coefficient of 0.00038 and an average transmissivity of $3,000 \mathrm{ft}^{2} / \mathrm{d}$ for Quaternary alluvium and an average storage coefficient of 0.0005 and average transmissivity of $1,750 \mathrm{ft}^{2} / \mathrm{d}$ for the Upper Cretaceous Judith River Formation (Moulder and others, 1960) was used for these calculations.

Most wells completed in the alluvium were installed with a 5-ft length of stainless-steel screen. In most places the thickness of the water-bearing zone ranged from 5 to $13 \mathrm{ft}$. Thus, in many wells completed in the alluvium, either the entire thickness or much of the thickness of the aquifer was penetrated and open to the screen. For wells completed in the Judith River Formation, the entire thickness of the aquifer was not fully penetrated, so only the area adjacent to the well screen contributed water to the well. Transmissivity was not estimated for unconfined conditions because most drillers' logs reported that water levels declined substantially in the pumped well; thus, the saturated thickness of the aquifers near the well probably was substantially decreased.

A synoptic-streamflow investigation was conducted on October 25, 1994, during near base-flow conditions to help determine ground- and surface-water interactions. Three two-person teams measured mainstem streamflow, major tributary streamflow, and selected canal diversions along three different reaches of the Little Bighorn River. Two sites, S11 and S16 (pl. 1), were measured twice as one team started and one team ended with these sites. A reconnaissance of minor tributaries on October 26, 1994, determined that streamflow from these sources did not increase flow of the Little Bighorn River during the synopticstreamflow investigation. Specific conductance of streamflow also was measured at each site. Streamflow was measured using standard USGS methods described by Rantz and others (1982).

Water-quality and quality-assurance samples were collected from selected wells to assess groundwater quality in the study area (table 7 at back of report). Ground-water samples were obtained from existing pump systems at a discharge point as close to each well as possible. Water-quality properties were measured in the field, and each sample was collected and processed as described by Knapton (1985). Samples were analyzed for major ions, trace elements, and radon. Additionally, water-quality information was obtained from the IHS. Water-quality data in this report from IHS included only those analyses that balanced electrochemically to within 5 percent. Two analyses obtained from IHS for wells W77 and W151 reported the concentration of sodium plus potassium rather than separate concentrations for each. Because potassium is a component of the water-quality diagrams of analyses, values of $5 \mathrm{mg} / \mathrm{L}$ were abitrarily used for the potassium concentration and $5 \mathrm{mg} / \mathrm{L}$ was subtracted from the sodium concentration to keep the same value for the sodium plus potassium ionic concentration. Similarly, for the analysis of water from well W60, a concentration for magnesium was not reported; thus, a value of $0.5 \mathrm{mg} / \mathrm{L}$ was arbitrarily used for the magnesium concentration. For wells that had more than one analysis of water, only the most recent analysis was used in water-quality diagrams or statistical summaries. 


\section{Location and Site Numbering System}

Ground-water sites are assigned location numbers according to their geographic position within the rectangular grid system used for the subdivision of public lands (fig. 2). The location number consists of as many as 14 characters. The first three characters specify the township and its position south (S) of the Montana Base Line. The next three characters specify the range and its position east (E) of the Montana Principal Meridian. The next two characters are the section number. The next three to four characters designate the quarter section (160-acre tract), the quarter-quarter section (40-acre tract), the quarter-quarter-quarter section (10-acre tract), and the quarter-quarter-quarter-quarter section (2.5-acre tract), respectively, in which the well or spring is located. These four subdivisions of the section are designated A, B, C, and D in a counterclockwise direction, beginning in the northeastern quadrant. The last two characters specify a sequence number to distinguish between multiple wells in a single tract. For example, as shown in figure 2, well 01S34E17CDCC01 is the first well inventoried in the SW 1/4 (C) of the SW 1/4 (C) of the SE 1/4 (D) of the SW 1/4 (C) of sec. 17, T. 1 S., R. 34 E. For clarity in the report, ground-water sites also are assigned a site number from W1 to W193 (fig. 2, table 4).

Eight-digit station-identification numbers for established surface-water sites represent the standard USGS numbering system for streamflow-gaging stations. For clarity in this report, established surfacewater sites, in addition to synoptic-streamflow sites, also are assigned a site number from S1 though S27 (pl. 1).

\section{Acknowledgments}

The author acknowledges with appreciation the many individuals who assisted in the study. Particular thanks are given to the well owners in the study area for allowing access to their wells. Appreciation also is extended to Mary Manydeeds and Robert Old Horn (BIA), for their field assistance and information about the study area; Connie Howe, Crow Environmental Protection Program (CEPP), for access to and information about the study area; Rex Harris and Bruce Fritzler (IHS), for access to drillers' logs and water-quality information; and DeAnn M. Dutton and Bruce M. Bochy (USGS), for their field assistance. Special thanks are given to Dave R. Johnson (USGS), for con- ducting the synoptic-streamflow investigation of the Little Bighorn River and for compilation, discussion, review, and interpretation of streamflow data.

\section{GROUND-WATER RESOURCES}

\section{Hydrogeologic Setting}

The study area is underlain by sedimentary rocks and deposits ranging in age from Mississippian to Quaternary (pl. 1). Rocks that range in age from Mississippian through Late Cretaceous consist of marine, nearshore, and coastal-plain deposits. These rocks were deposited primarily in broad, shallow seas or nearshore environments extending across most of what is now the State of Montana. Regional tectonic activity produced uplifts that interrupted marine and near-shore deposition, eroded pre-existing rocks, and caused coastal-plain sediments to be deposited. Rocks that are Tertiary in age consist of the Paleocene Tullock Member of the Fort Union Formation. These rocks were deposited in a large structural basin that formed as a result of intermittent crustal movements throughout Late Cretaceous and Tertiary time. The area became a depositional center for locally derived sediment in fluvial and lacustrine depositional environments (Flores and Ethridge, 1985). By late Miocene to early Pliocene time, renewed faulting uplifted the area, and rivers and streams eroded some pre-existing Tertiary deposits. By Pleistocene time, the Bighorn Mountains and adjacent areas were eroded to their general present-day configuration (Glaze and Keller, 1965). Pleistocene streams continued to deposit gravel, sand, silt, and clay across channels, flood plains, and terraces on the valley floors and valley margins. Extensive terraces formed along the western side of the present Little Bighorn River valley. Major tectonic activity was assumed to have ended in late Tertiary time, but the area probably was active periodically during the Quaternary (Agard, 1989). Deposits that are Quaternary in age consist of unconsolidated gravel, sand, silt, and clay.

A principal aquifer along the Little Bighorn River includes Quaternary alluvium of flood plains and low and high terraces. Quaternary low-terrace deposits underlie about $10 \mathrm{mi}^{2}$ and generally extend along the Little Bighorn River southwest of Wyola. Because alluvium and low-terrace deposits probably function as 


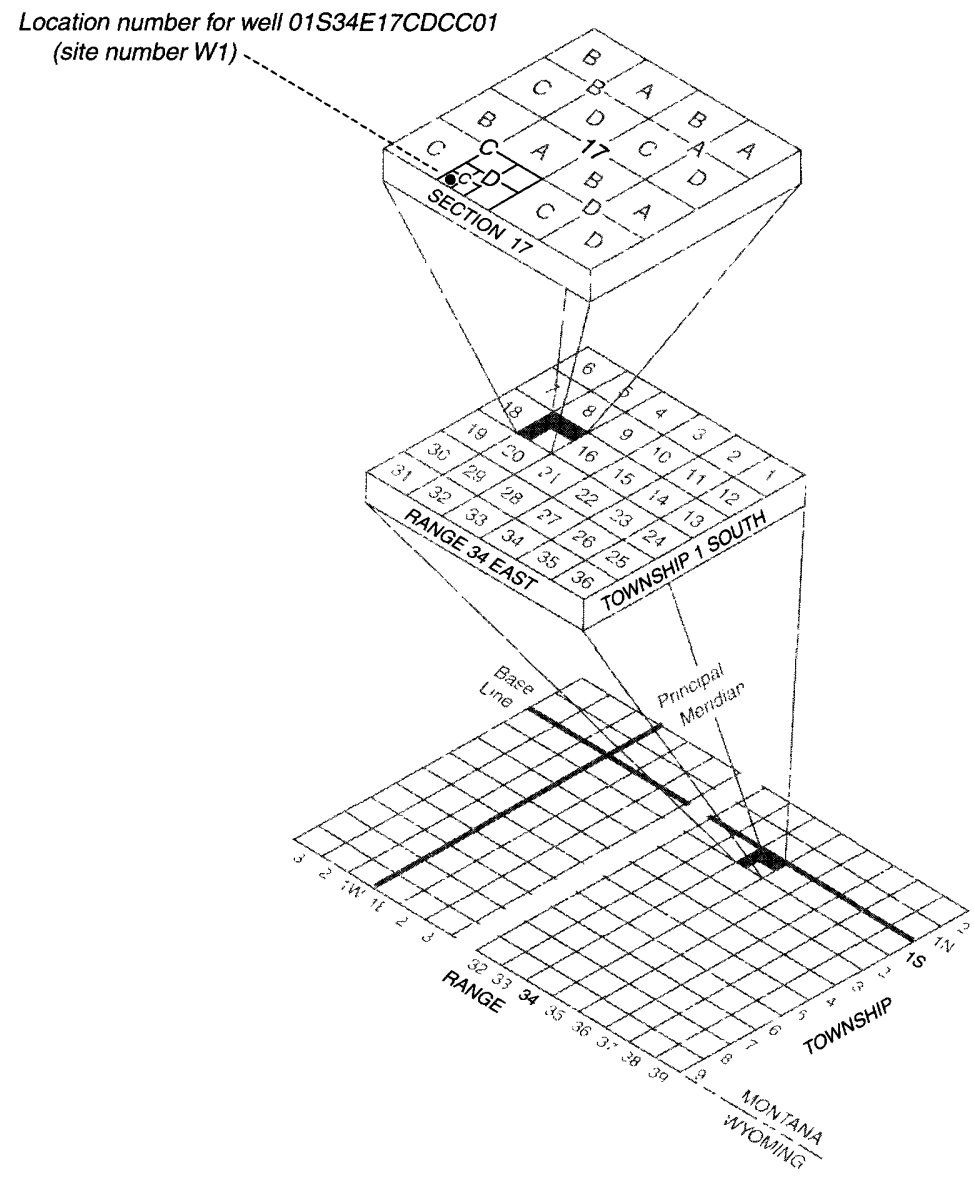

Figure 2. Numbering system for ground-water sites.

one hydrogeologic unit, these two deposits are hereinafter called Quaternary alluvium. The Upper Cretaceous Judith River Formation also is an important aquifer. Other aquifers in the area include the Tertiary Tullock Member of the Fort Union Formation, Upper Cretaceous Hell Creek Formation and Fox Hills Sandstone, and sandy hydrogeologic units in the Upper Cretaceous Bearpaw Shale (pl. 1). The general hydrogeologic setting of the study area consists of unconsolidated gravel, sand, silt, and clay deposits having moderate-to-low permeability underlain by finegrained sandstone and shale generally having a lower permeability. Thickness and extent of both the alluvium and the Judith River Formation vary throughout the study area. The availability of water from these hydrogeologic units depends on aquifer thickness, extent of interstitial or interbedded silt and clay, and amount of recharge from the Little Bighorn River,
Lodge Grass Creek, irrigation, or other hydrogeologic units. Quaternary alluvium and the Judith River Formation are discussed in detail because most water supplies originate from these two aquifers and because data are insufficient to describe other aquifers.

\section{Quaternary Alluvium}

Quaternary alluvium underlies an area of about $94 \mathrm{mi}^{2}$ located primarily along the Little Bighorn River and its perennial tributaries, Lodge Grass and Pass Creeks, and large ephemeral tributaries, Owl and Reno Creeks. Quaternary alluvium is composed of unconsolidated gravel, sand, silt, and clay and generally is less than about $30 \mathrm{ft}$ thick. Thickness of the probable water-bearing zone within alluvium ranges from 2 to $39 \mathrm{ft}$, with a median of $9 \mathrm{ft}$. Many of the drillers' logs reported a thickness between about 5 and $13 \mathrm{ft}$. 
On the basis of information from Moulder and others (1960) and information from drillers' logs about static-water levels and top of the probable water-bearing zone near wells, water in alluvium in the study area can be confined, unconfined, or leaky-confined. In most areas along the Little Bighorn River, several feet of fine-grained sediment overlies the coarse-grained sediments that form the water-bearing zone in alluvium. Thus, the fine-grained sediment forms a confining or leaky-confining layer, which can restrict direct recharge from nearby surface-water sources. Except where sandstone within the Judith River Formation underlies alluvium, several thousand feet of finegrained, low permeability sandstone and shale of Upper and Lower Cretaceous rocks form a basal layer.

Aquifer tests conducted at two wells completed in Quaternary alluvium as part of an earlier investigation (Moulder and others, 1960) ${ }^{1}$ yielded estimates of hydraulic conductivity of about 130 and $210 \mathrm{ft} / \mathrm{d}$, transmissivity of 2,000 and $4,000 \mathrm{ft}^{2} / \mathrm{d}$, and storage coefficients that ranged from about $2.8 \times 10^{-7}$ to $2.6 \times 10^{-3}$. In this study, the specific capacity of wells (table 6) completed in Quaternary alluvium ranged from 0.31 to 30 (gal/min)/ft, with a median of $2.8(\mathrm{gal} / \mathrm{min}) / \mathrm{ft}$. Transmissivity estimates from specific-capacity tests ranged from 230 to $6,900 \mathrm{ft}^{2} / \mathrm{d}$, with a median of $810 \mathrm{ft}^{2} / \mathrm{d}$ and an average of about $1,400 \mathrm{ft}^{2} / \mathrm{d}$. Reported well yields from Quaternary alluvium ranged from 4 to 50 $\mathrm{gal} / \mathrm{min}$, with a median of about $15 \mathrm{gal} / \mathrm{min}$. After pumping at relatively low rates (generally less than about $13 \mathrm{gal} / \mathrm{min}$ ), water levels in many wells fell below the top of the water-bearing zone, resulting in unconfined conditions at the well. Low hydraulic conductivity and transmissivity, low specific capacity, and low well yield are typical of alluvium deposited by rivers having a small carrying and sorting capacity, which results in deposits containing substantial quantities of fine-grained material. In addition, these deposits might also contain discontinuous or poorly connected lenses of coarse-grained material.

The direction of water movement in Quaternary alluvium can be determined from the potentiometric surface shown in plate 1 . Water in the aquifer moves at right angles to the contours and downgradient. In the study area, the direction of water flow generally is from the valley margins, where alluvium is recharged, toward the Little Bighorn River, where water from these deposits discharges to the river. The gradient of the potentiometric surface varies. South of Wyola near the valley margins, the gradient is steep and is about $0.02(100 \mathrm{ft} / \mathrm{mi})$, but decreases to $0.002(10 \mathrm{ft} / \mathrm{mi})$ along the river. The gradient near Benteen is 0.003 (18 ft/mi), and north of Crow Agency the gradient is $0.004(22 \mathrm{ft} / \mathrm{mi})$.

\section{Recharge}

Estimates of recharge and discharge components (developed as part of this study) for the Quaternary alluvium are summarized in table 1 . Because of the large areal extent of Quaternary alluvium, the groundand surface-water interactions, and the complexity of the irrigation systems in the study area, accurately determining most of the components of recharge and discharge is beyond the scope of this study. Therefore, these components are discussed only qualitatively. No attempt was made to balance recharge and discharge components in a hydrologic budget. However, recharge and discharge estimates could be used as a conceptual model for water flow in the Quaternary alluvium.

Recharge to Quaternary alluvium is by infiltration and subsequent percolation of precipitation, canal leakage, excess applied irrigation water, bank storage, and by subsurface inflow from alluvium in small ephemeral tributaries adjacent to the Little Bighorn valley (Moulder and others, 1960) and from the underlying Upper Cretaceous Judith River Formation. Infiltration and subsequent percolation of precipitation typically recharge the alluvium during the fall and winter before the ground freezes, and early spring when evapotranspiration is minimal. Average precipitation (fig. 3) in the study area from October through April is 6.7 in. (Western Regional Climate Center, 2001); therefore, recharge from precipitation during this period cannot be more than about 33,700 acre-ft/yr. Actual recharge from precipitation probably is substantially less than this quantity because some of this precipitation will sublimate, evaporate, run off, transpire, or be retained as soil moisture. Water-level rises in some

\footnotetext{
${ }^{1}$ Moulder and others (1960) acknowledged that aquifer-test results were erratic and might be somewhat in error. However, the values appeared to be valid for this type of aquifer.
} 
Table 1. Estimates of recharge and discharge components for Quaternary alluvium and the Upper Cretaceous Judith River Formation along the Little Bighorn River and adjacent areas, Montana

[Abbreviations: acre-ft/yr, acre-foot per year; $\mathrm{ft}^{3} / \mathrm{s}$, cubic foot per second. Symbols: <, quantity less than this value; $\ll$, quantity substantially less than this value; $>$, quantity greater than this value; --, not determined]

\begin{tabular}{|c|c|c|}
\hline \multirow{2}{*}{ Component } & \multicolumn{2}{|c|}{ Estimated quantity or range } \\
\hline & (acre-ft/yr) & $\left(\mathrm{ft}^{3} / \mathrm{s}\right)$ \\
\hline \multicolumn{3}{|l|}{ Recharge to Quaternary alluvium } \\
\hline Infiltration of precipitation & $<<33,700$ & $<<47$ \\
\hline Canal leakage and excess irrigation water & -- & -- \\
\hline Bank storage & -- & -- \\
\hline Inflow from ephemeral tributaries & -- & -- \\
\hline Inflow from the Judith River Formation & 175 to 1,750 & .24 to 2.4 \\
\hline \multicolumn{3}{|c|}{ Discharge from Quaternary alluvium } \\
\hline Evapotranspiration & -- & -- \\
\hline Withdrawals from wells & $>130$ & $>.02$ \\
\hline Outflow to drains & -- & -- \\
\hline $\begin{array}{l}\text { Outflow to the Little Bighorn River determined from baseflow } \\
\text { calculations from streamflow-gage records (water years 1953- } \\
55 ; 1982-94 \text { ) }\end{array}$ & 32,600 & 45 \\
\hline $\begin{array}{l}\text { Outflow to the Little Bighorn River determined from low-flow } \\
\text { investigation (October 1994) }\end{array}$ & $<39,800$ & $<55$ \\
\hline \multicolumn{3}{|c|}{ Recharge to Upper Cretaceous Judith River Formation } \\
\hline Infiltration of precipitation & $<<26,900$ & $<<37$ \\
\hline Canal leakage & -- & -- \\
\hline Bank storage & -- & -- \\
\hline \multicolumn{3}{|c|}{ Discharge from Upper Cretaceous Judith River Formation } \\
\hline Outflow to Quaternary alluvium & 175 to 1,750 & .24 to 2.4 \\
\hline Withdrawals from wells & $<130$ & $<.08$ \\
\hline Evapotranspiration & -- & -- \\
\hline
\end{tabular}

wells during the fall, winter, and spring (when recharge can be greater than discharge) probably result from a combination of infiltration of precipitation before the ground freezes or after it thaws, canal leakage where water is maintained in canals for stock use, subsurface inflow from alluvium in small ephemeral tributaries, or subsurface inflow from the Judith River Formation (fig. 4, for example, wells W13, W22, W26, W125, W131, W152, W163, and W174). Generally, precipitation probably does not substantially recharge alluvium from May through September because evapotranspiration by crops and natural vegetation typically exceeds precipitation in the study area during the growing season in most years (Moulder and others, 1960; Toy and Munson, 1978). Above-normal precipitation during some months in
1995 (fig. 3) in the study area (Western Regional Climate Center, 2001) probably caused water levels in some wells, in part, to increase in May and June 1995. Water levels in some wells completed in alluvium decreased generally from June through September, 1995 (fig. 4; for example, wells W13, W22, W131, W144, W152, W174); thus, recharge generally is assumed to be less than discharge during this time.

The quantity of recharge to Quaternary alluvium by canal leakage and infiltration of water applied to irrigated fields is unknown but could be large. Moulder and others (1960) estimated an average leakage rate of $0.00038 \mathrm{ft}^{3} / \mathrm{s}$ per foot of canal length, based on a determination that canal leakage along the Agency Canal in 


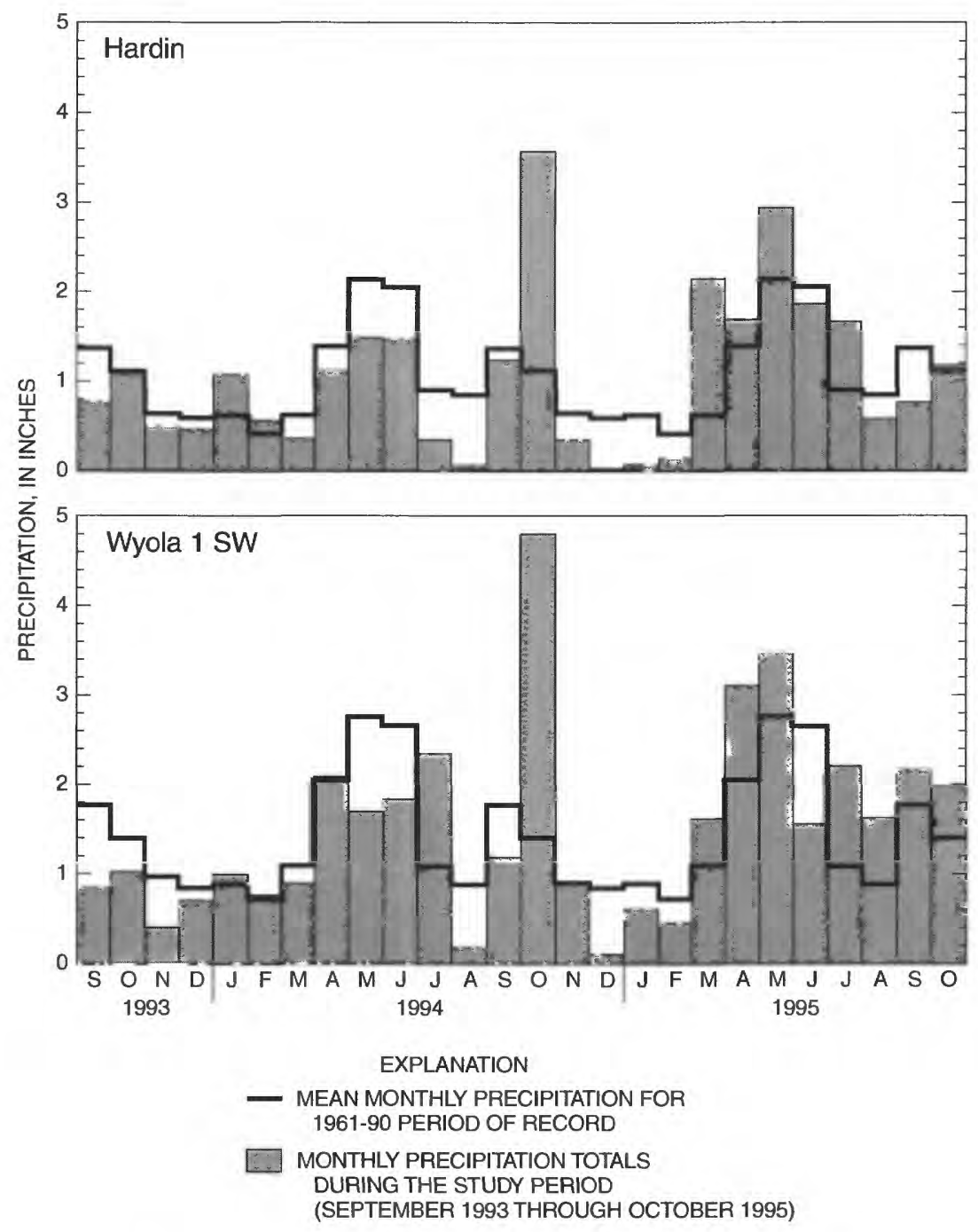

Figure 3. Mean monthly precipitation for the $1961-90$ period of record and monthly precipitation totals for the study period at Hardin and near Wyola, Montana. Data from the Western Regional Climate Center (2001).

sec. 1, T. 3 S., R. 34 E., ranged from 100 to 400 gallons per day per foot of canal length. The volume of water released to the canal systems in the study area is unknown. Some streamflow from Lodge Grass Creek is stored in the Lodge Grass Storage Reservoir (about 23,000 acre feet) and then released to the Lodge Grass Canal No. 1; unused water in the canal flows to the Little Bighorn River (U.S. Geological Survey, 1996). Applied irrigation water only recharges the aquifer when the volume of applied water plus precipitation exceeds evapotranspiration. Information about the volume of irrigation water applied to fields also is unavailable.
The quantity of recharge to Quaternary alluvium by infiltration of bank storage during high streamflow is unknown. Figure 5 shows water-level rises due to the effects, in part, of bank storage in wells W26, W125, W163, and W184. Water levels in these wells generally increased during sustained streamflow peaks of the Little Bighorn River and then decreased as streamflow decreased.

The quantity of recharge to Quaternary alluvium by subsurface inflow from alluvium in small ephemeral and intermittent tributaries also is unknown. Ephemeral and intermittent streams likely provide recharge during intense or abundant rainfall and runoff as water infiltrates into alluvial deposits and alluvial fans that 

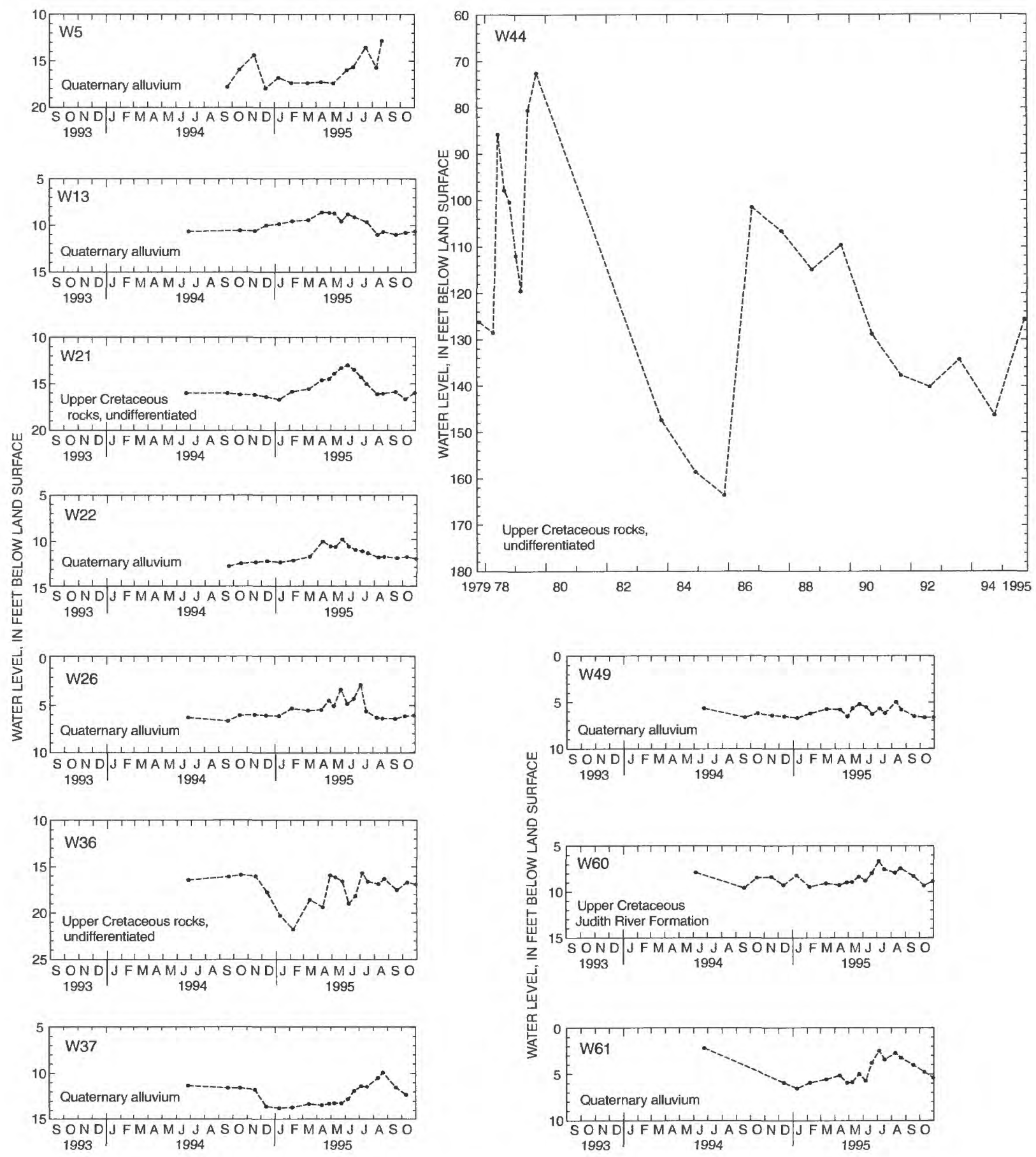

Figure 4. Hydrographs of water levels in selected wells along the Little Bighorn River and adjacent areas, Montana. 

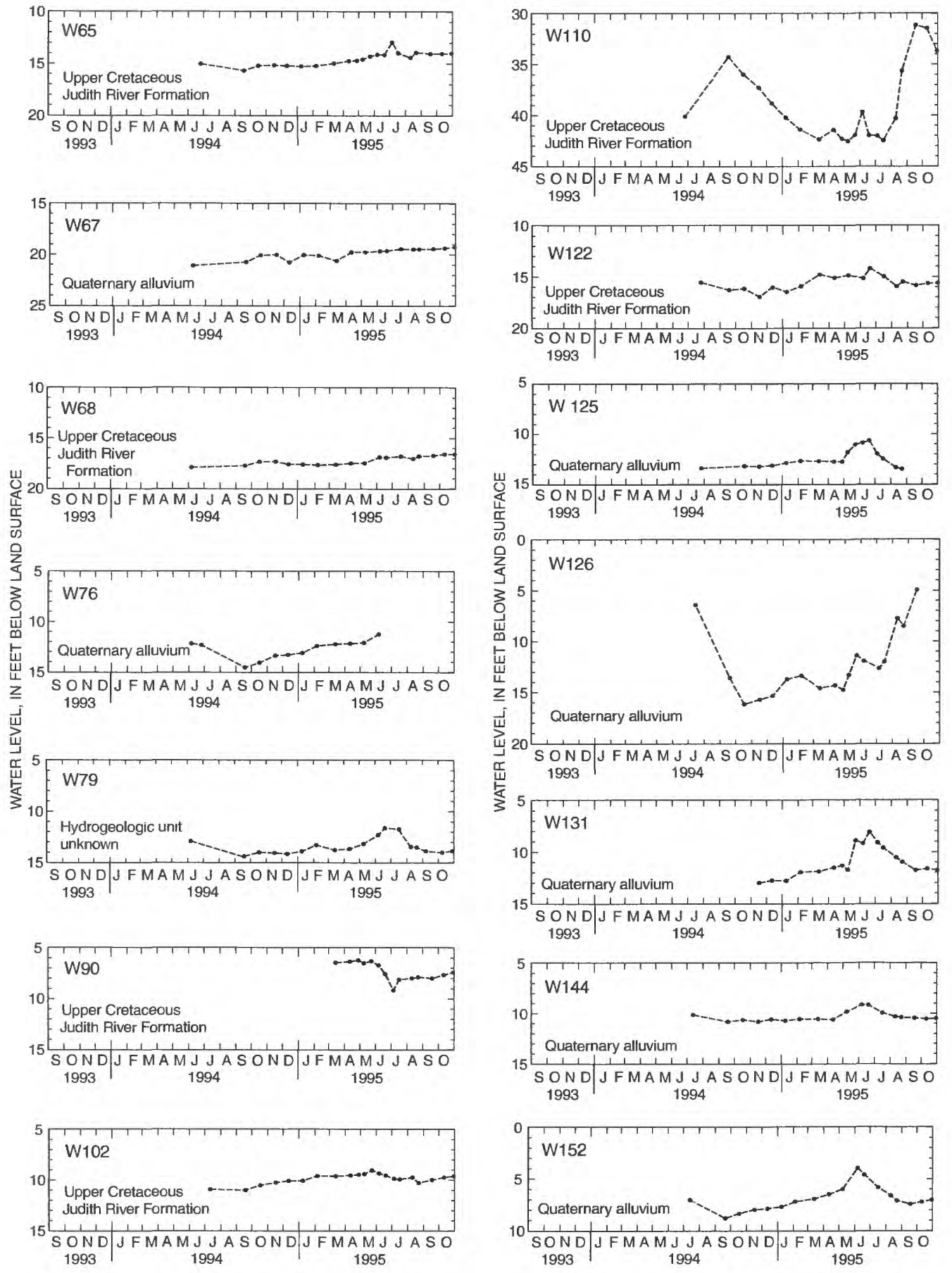

Figure 4. Hydrographs of water levels in selected wells along the Little Bighorn River and adjacent areas, Montana (Continued). 

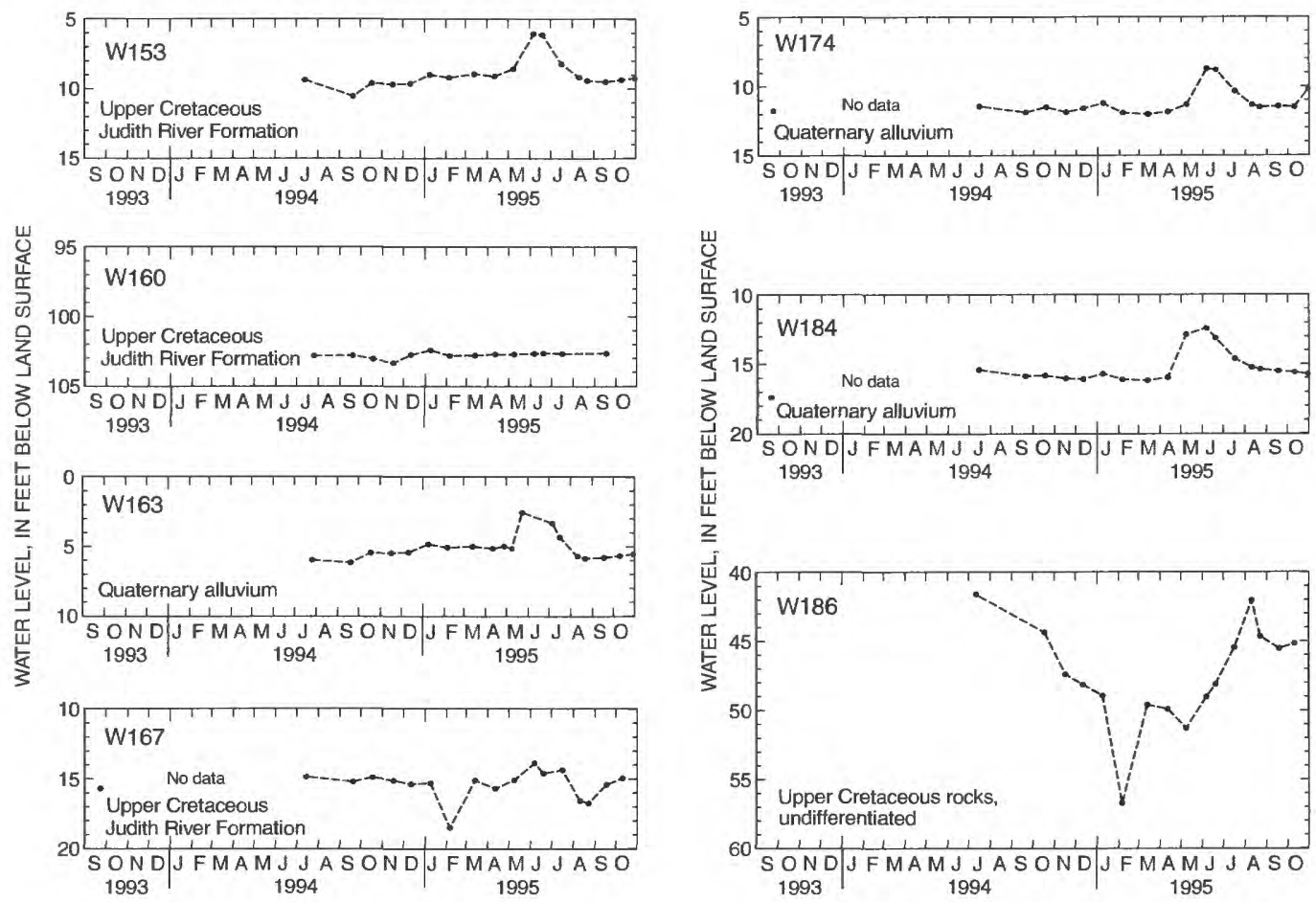

Figure 4. Hydrographs of water levels in selected wells along the Little Bighorn River and adjacent areas, Montana (Continued).

flank the Little Bighorn River valley. Because many ephemeral and intermittent streams do not have welldefined channels, some surface runoff might seep into the ground. This type of recharge might occur where the altitude of the ground-water table is below the altitude of the ephemeral or intermittent stream channel. Along Shoulder Blade Creek, water-level altitudes in wells W66, W67, W68, W69 and nearby altitudes of the stream channel indicate that this creek could lose water to the subsurface, recharging the alluvium and Judith River Formation. For the period of study, water levels in well W67, which is completed in the alluvium along Shoulder Blade Creek (pl. 1, fig. 4), showed an overall increasing trend in response to above-normal precipitation during some months in 1995. Ground water in the alluvium along Shoulder Blade Creek most likely flowed towards the Little Bighorn valley and eventually recharged the alluvium along the Little Bighorn River. Similar ground-water flow conditions likely occur along other ephemeral and intermittent tributaries of the Little Bighorn River.

Recharge to Quaternary alluvium by groundwater flowing from the underlying Judith River Formation is indicated by an upward component of flow in the Judith River Formation. Water levels in some wells completed in the Judith River Formation can be higher than water levels in wells completed in the alluvium, indicating that ground water is flowing upward from the Judith River Formation to recharge the Quaternary alluvium.

The amount of ground water flowing from the Judith River Formation into the alluvium can be calculated using the Darcy equation:

$$
Q=K I A \times 365 \text { days per year }
$$

where:

$$
\begin{array}{ll}
Q \quad= & \begin{array}{c}
\text { ground-water flow from the Judith } \\
\text { River Formation, in acre-feet } \\
\text { per year; }
\end{array} \\
K \quad= & \begin{array}{c}
\text { hydraulic conductivity, in feet per } \\
\text { day; }
\end{array} \\
I \quad & \begin{array}{c}
\text { hydraulic gradient, dimension- } \\
\text { less; and }
\end{array} \\
A \quad= & \begin{array}{c}
\text { cross-sectional area of the Judith } \\
\text { River Formation, in acres. }
\end{array}
\end{array}
$$

Recharge to Quaternary alluvium from the underlying Judith River Formation is estimated to range from about 175 to 1,750 -acre-ft/yr based on an 


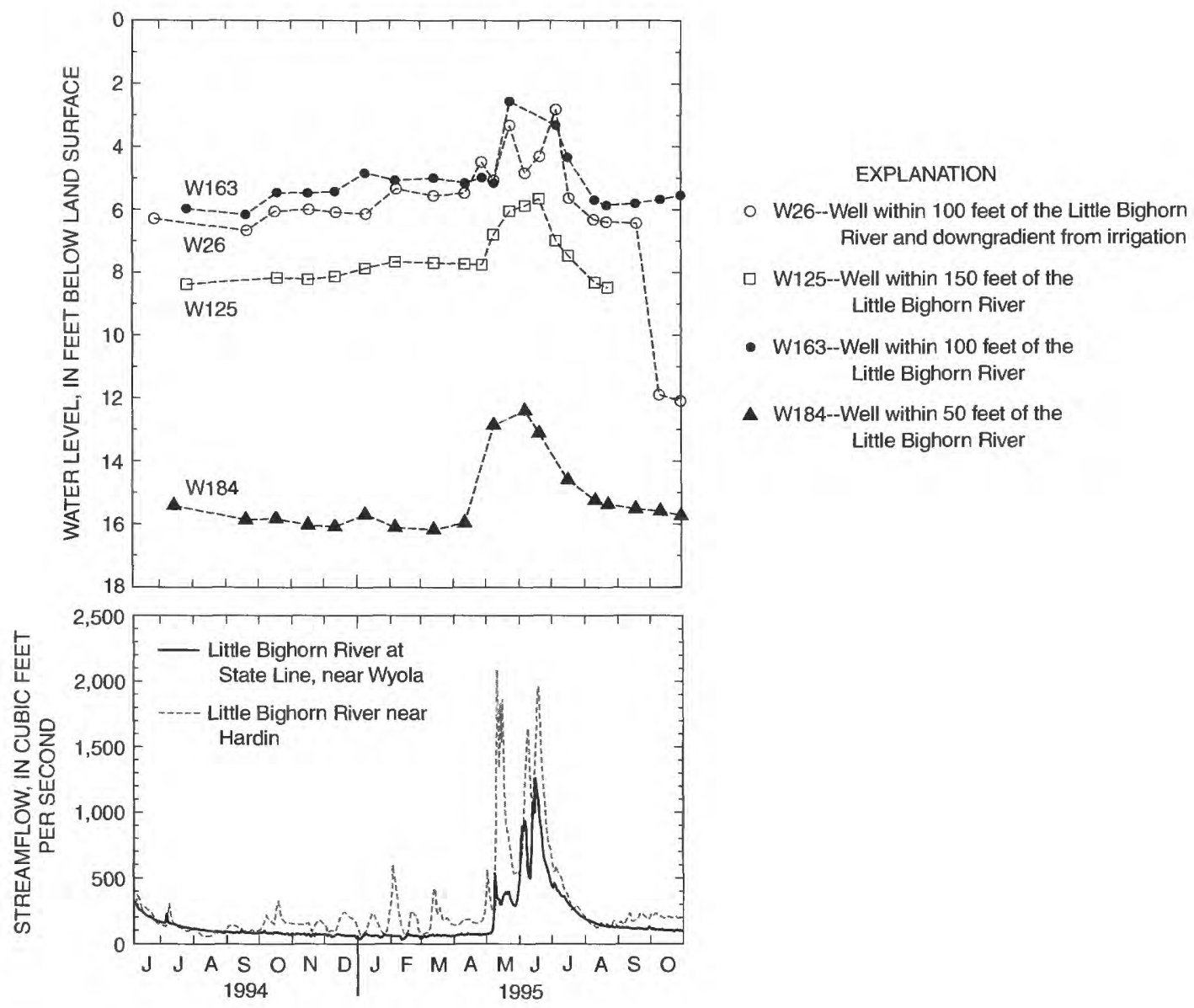

Figure 5. Seasonal variation in water levels in wells completed in Quaternary alluvium and comparison to streamflow of the Little Bighorn River, Montana.

areal extent of about 24,960 acres $\left(39 \mathrm{mi}^{2}\right)$ where the Judith River Formation underlies alluvium, a vertical hydraulic gradient of 0.07 (determined from wells W47 and W48), and vertical hydraulic conductivities that range from 0.1 to $1.0 \mathrm{ft} / \mathrm{d}$. This estimate also is based on the assumption that vertical gradients are the same throughout the study area and that the vertical hydraulic conductivity is about an order of magnitude less than the horizontal hydraulic conductivity (about 8 and $50 \mathrm{ft} / \mathrm{d}$; Moulder and others, 1960). However, vertical gradients and vertical hydraulic conductivities probably vary throughout the study area.

\section{Discharge}

Discharge from Quaternary alluvium is primarily through evapotranspiration, withdrawals from wells, flow to irrigation drains, and subsurface outflow to the Little Bighorn River. Alfalfa and pasture grasses are cultivated for hay crops on most alluvium. Although most water needs by alfalfa and pasture grasses probably were met by sprinkler and flood irrigation (from surface-water sources) and precipitation during the 1995 growing season, diurnal ground-water-level fluctuations can indicate discharge by evapotranspiration, particularly during warm summer days when the water needs of crops can be substantial (Dollhopf and others, 1979). The quantity of discharge from the alluvium by evapotranspiration is unknown. Moulder and others (1960) documented the effects of evapotranspiration on water-level fluctuations in some wells completed in the alluvium along the Little Bighorn River and concluded daily water-level fluctuations were the result of evapotranspiration during the growing season. Additionally, 
they concluded that from mid-July through September, recharge could exceed discharge or discharge could exceed recharge, depending on variations in evapotranspiration rate, canal stage, and amount of precipitation. Some water levels in wells completed in the alluvium decreased during June through September 1995 reflecting a decrease in ground-water storage concurrent with the irrigation season (wells W22, W49, and W144; fig. 4). Thus, discharge exceeded recharge during this period. For the 1995 growing period, this decrease in water levels represents a decrease in storage that probably is at least in part due to evapotranspiration.

Water in the Quaternary alluvium is primarily used for either domestic or stock-watering purposes. Water from alluvium is not used for irrigation. Water withdrawn from wells for domestic use in the entire study area was estimated to be about 260 acre-ft/yr. This quantity was estimated on the basis of a statewide average withdrawal rate of $78 \mathrm{gal} / \mathrm{d}$ per person (Montana Department of Natural Resources and Conservation, 1986) and an estimated population of about 3,000 people (approximate population of the eastern one-half of Big Horn County living outside of the Towns of Lodge Grass and Crow Agency, 2000 census data; Montana Department of Commerce, 2002). This estimate assumes that most people living in the eastern one-half of Big Horn County live along the Little Bighorn River and use water from either the Quaternary alluvium or the Judith River Formation. Quaternary alluvium underlies $94 \mathrm{mi}^{2}$ of the study area and the Judith River Formation underlies about $39 \mathrm{mi}^{2}$ of alluvium. Because the alluvium is shallower than the Judith River Formation, it is likely that at least one-half of the 260 acre- $\mathrm{ft} / \mathrm{yr}$ is withdrawn from the alluvium

(table 1). Withdrawals from wells for stock-watering purposes is unknown but is assumed to be small because surface water from the river and canals is used extensively for stock watering along the alluvial valley.

The quantity of discharge from Quaternary alluvium to irrigation drains is unknown, but might be large. Moulder and others (1960) determined that for many areas from Lodge Grass to the confluence of the Little Bighorn and Bighorn Rivers the high water table during the irrigation season caused extensive waterlogging. Irrigation drains reduced waterlogging in some areas by providing a surface conduit to discharge excess near-surface ground water.

Discharge from the Quaternary alluvium by subsurface outflow to the Little Bighorn River was not measured directly, but can be inferred from historical base-flow conditions and a 1994 synoptic-streamflow investigation of the Little Bighorn River. Discharge from the alluvium during base-flow conditions (generally November through February) for the period of concurrent record, 1953-55 and 1982-94, can be inferred from long-term streamflow records from sites S2, S4, S7, S25, and S27 (fig. 6, pl. 1). The long-term meanmonthly streamflow (average of the monthly mean streamflow values for each year of record) at sites S2 and S4 (Little Bighorn River and Pass Creek) was added and then the total was subtracted from the longterm mean-monthly streamflow at site S7 (Little Bighorn River below Pass Creek). Likewise, the long-term mean-monthly streamflow at sites S7 and S27 (Lodge Grass Creek) was added and then the total was subtracted from the long-term mean-monthly streamflow at site S25 (near the mouth of the Little Bighorn River). Using the flow at site S27 assumes that the long-term mean-monthly streamflow at site S27 was the same as at site S13 near the mouth of Lodge Grass Creek. The difference in streamflow between sites S27 and S13 on Lodge Grass Creek is not known, but presumably is minor during base-flow conditions.

The difference in the long-term mean-monthly streamflow along the upper Little Bighorn River and Pass Creek above site S7 (fig. 6) ranged from about 18 to $23 \mathrm{ft}^{3} / \mathrm{s}$ and averaged $20 \mathrm{ft}^{3} / \mathrm{s}$ (table 2). Thus, discharge from the alluvium is equivalent to about 13,000 to 16,700 acre-ft/yr, assuming the discharge rate throughout the year is the same as that during the November through February base-flow period. On the basis of this estimated range, about 0.79 to $1.0 \mathrm{ft}^{3} / \mathrm{s}$ of water per mile discharges primarily from the alluvium along the 23-mile upper reach of the Little Bighorn River valley.

The difference in the long-term mean-monthly streamflow along the lower Little Bighorn River for the same 4 months from site $S 7$ to $S 25$ (fig. 6) ranged from about 11 to $55 \mathrm{ft}^{3} / \mathrm{s}$ (average of $24 \mathrm{ft}^{3} / \mathrm{s}$, table 2), which is equivalent to about 8,000 to 39,800 acre- $\mathrm{ft} / \mathrm{yr}$. On the basis of this estimated range, about 0.26 to $1.3 \mathrm{ft}^{3} / \mathrm{s}$ of water per mile discharges primarily from the alluvium along the 44-mile lower reach of the Little Bighorn River. Thus, the long-term mean-monthly gain in flow for the entire 67 miles of the Little Bighorn River valley from site $S 2$ to $S 25$ ranged from about 35 to 73 $\mathrm{ft}^{3} / \mathrm{s}$ and averaged $45 \mathrm{ft}^{3} / \mathrm{s}$ (equivalent to 32,600 acre$\mathrm{ft} / \mathrm{yr})$. 


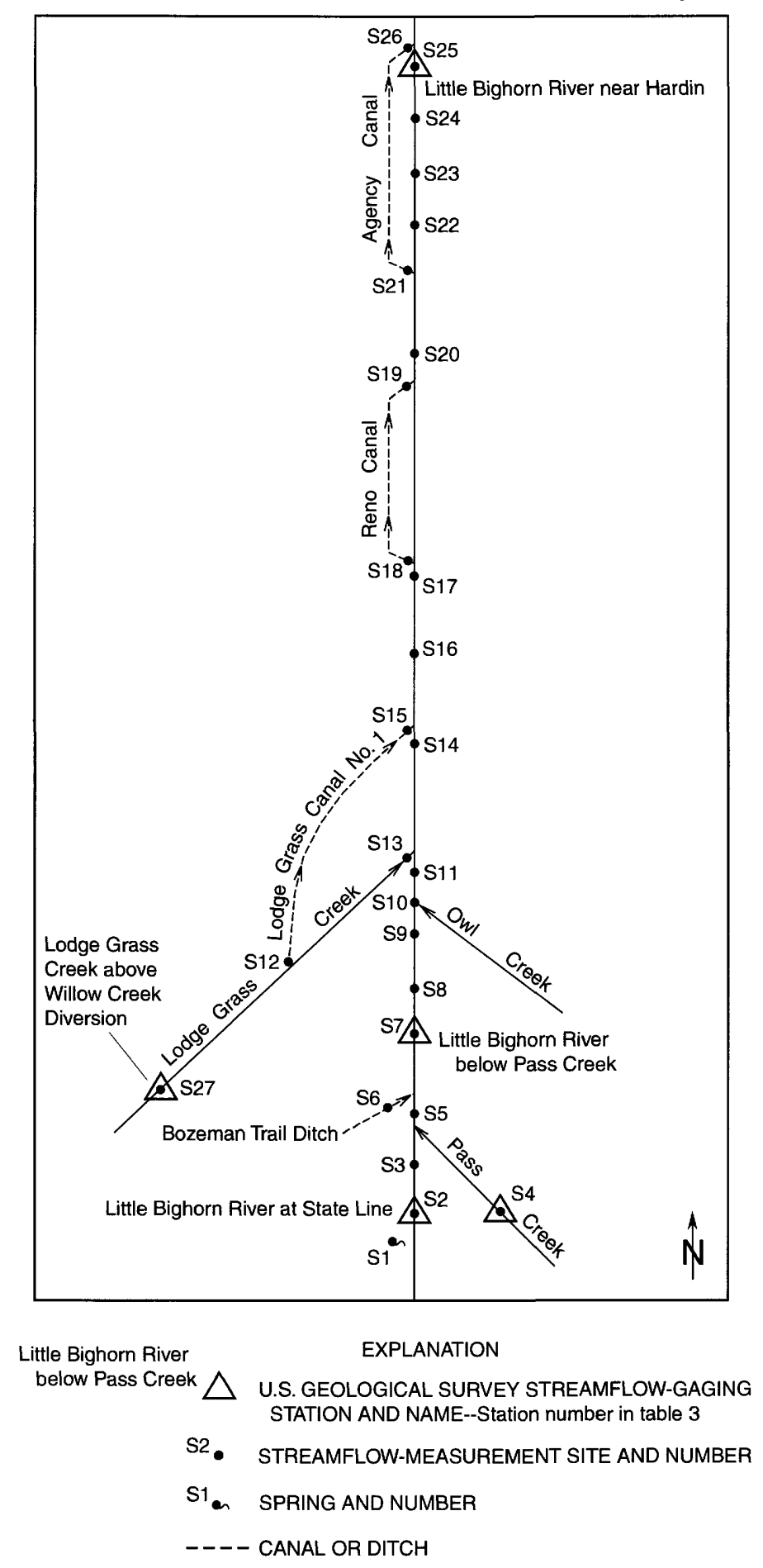

Figure 6. Synoptic-streamflow measurement sites along the Little Bighorn River, Montana. 
Table 2. Gains in streamflow calculated from concurrent streamflow-gage records during base flow for the Little Bighorn River, Pass Creek, and Lodge Grass Creek, Montana

[Site numbers described in text. Figure 6 shows schematic diagram of streamflow-gaging sites. Streamflow data are for the concurrent period of record, water years 1953-55 and 1982-94. Streamflow gains in the upper Little Bighorn River valley are represented by values shown for site S7; gains in the lower Little Bighorn River valley are represented by values shown for site S25. Difference in streamflow, for the entire period of record indicated for the month, is the mean monthly: for site S7-the combined long-term mean-monthly streamflow for sites S2 plus S4, subtracted from the concurrent long-term mean-monthly streamflow at site S7; for site S25-the combined long-term mean-monthly streamflow for S7 plus S27 subtracted from the concurrent long-term mean-monthly streamflow at site S25. Linear valley distance along the upper Little Bighorn River and Pass Creek (sites S2 and S4) to the upper Little Bighorn River at site $\mathbf{S 7}$ is about 23 miles. Linear valley distance along the lower Little Bighorn River from site S7 to site S25 is about 44 miles. Abbreviations: $\mathrm{ft} 3 / \mathrm{s}$, cubic feet per second; LBHR, Little Bighorn River. Symbol: --, not determined]

\begin{tabular}{|c|c|c|c|c|}
\hline $\begin{array}{c}\text { Abbreviated } \\
\text { streamflow-gaging } \\
\text { station name }\end{array}$ & $\begin{array}{c}\text { Site } \\
\text { number }\end{array}$ & $\begin{array}{c}\text { Long-term } \\
\text { mean-monthly } \\
\text { streamflow }\end{array}$ & $\begin{array}{c}\text { Difference in long- } \\
\text { term mean-monthly } \\
\text { streamflow } \\
\left(\mathrm{ft}^{3} / \mathrm{s}\right)\end{array}$ & $\begin{array}{c}\text { Gain in } \\
\text { streamflow } \\
\text { per mile } \\
\left(\mathrm{ft}^{3} / \mathrm{s}\right)\end{array}$ \\
\hline \multicolumn{5}{|c|}{ November } \\
\hline LBHR at State Line & S2 & 67.0 & -- & -- \\
\hline Pass Creek & S4 & 16.6 & -- & -- \\
\hline LBHR below Pass Creek & S7 & 105 & 21.4 & 0.93 \\
\hline LBHR near Hardin & S25 & 136 & 14.0 & .32 \\
\hline Lodge Grass Creek & S27 & 17.0 & -- & -- \\
\hline \multicolumn{5}{|c|}{ December } \\
\hline LBHR at State Line & S2 & 61.0 & -- & - \\
\hline Pass Creek & S4 & 15.3 & -- & - \\
\hline LBHR below Pass Creek & S7 & 95.0 & 18.7 & .81 \\
\hline LBHR near Hardin & S27 & 127 & 16.6 & .38 \\
\hline Lodge Grass Creek & S25 & 15.4 & - & -- \\
\hline \multicolumn{5}{|c|}{ January } \\
\hline LBHR at State Line & S2 & 58.0 & -- & - \\
\hline Pass Creek & S4 & 18.8 & -- & -- \\
\hline LBHR below Pass Creek & S7 & 100 & 23.2 & 1.0 \\
\hline LBHR near Hardin & S25 & 127 & 11.4 & .26 \\
\hline Lodge Grass Creek & S27 & 15.6 & -- & -- \\
\hline \multicolumn{5}{|c|}{ February } \\
\hline LBHR at State Line & S2 & 55.0 & -- & -- \\
\hline Pass Creek & S4 & 26.9 & -- & -- \\
\hline LBHR below Pass Creek & S7 & 100 & 18.1 & .79 \\
\hline LBHR near Hardin & S25 & 171 & 55.1 & 1.3 \\
\hline Lodge Grass Creek & S27 & 15.9 & -- & -- \\
\hline
\end{tabular}

Gains in streamflow from the Judith River Formation also are possible because this formation crops out along the river from near Wyola to Benteen. However, gains in streamflow from the Judith River Formation would not be determined from available streamflow data.

Discharge from Quaternary alluvium also can be inferred from synoptic-streamflow measurements made during base-flow conditions along the Little Bighorn River. A synoptic-streamflow investigation was conducted on October 25, 1994 (figs. 6 and 7, table 3), to spatially delineate and quantify gains in streamflow during a period absent of precipitation runoff and minimally affected by evapotranspiration. Gains or losses of about 5 percent or less of the measured streamflow were not considered to necessarily represent flow 
changes because this range of variability is within the typical error range for measurement precision. Also, diurnal variation may have caused flow changes of this magnitude. Two sites where replicate streamflow measurements were made (S11 and S16, table 3) indicated measurement differences of about 1 to 4 percent.

Gains in streamflow from sources other than tributaries were notable for two reaches along the Little Bighorn River (figs. 6 and 7, table 3). First, from sites $\mathrm{S} 2$ to $\mathrm{S} 5$, streamflow increased by about $38 \mathrm{ft}^{3} / \mathrm{s}$, after subtracting tributary inflow from Pass Creek (site S4).
Some of this increase might be attributed to unmeasured tributary inflow above Black Gulch and unmeasured irrigation return flow. In addition, some of this increase can be attributed to ground-water discharge from the Judith River Formation where it crops out between sites S3 and S7, and from older rocks where they crop out between S2 and Sport Creek. Thus, the quantity of ground water discharged from Quaternary alluvium between sites $\mathrm{S} 2$ and $\mathrm{S} 5$ is difficult to calculate from these synoptic measurements, but was less than $38 \mathrm{ft}^{3} / \mathrm{s}$ (less than $2.7 \mathrm{ft}^{3} / \mathrm{s}$ of water per mile) in

Table 3. Synoptic-streamflow and specific-conductance measurements along the Little Bighorn River, Montana, October 25, 1994

[Site numbers described in text. Remarks: S, USGS streamflow-gaging station and number; O, overlap site where same site was measured by two different teams. Abbreviations: $\mathrm{ft}^{3} / \mathrm{s}$, cubic feet per second; $\mu \mathrm{S} / \mathrm{cm}$, microsiemens per centimeter at 25 degrees Celsius. Symbols: --, no data or not applicable; ( ), number in parentheses denotes a decrease in streamflow]

\begin{tabular}{|c|c|c|c|c|c|}
\hline $\begin{array}{l}\text { River, creek, } \\
\text { irrigation supply, } \\
\text { or spring }\end{array}$ & Site number & $\begin{array}{c}\text { Discharge } \\
\left(\mathrm{ft}^{3} / \mathrm{s}\right)\end{array}$ & $\begin{array}{c}\text { Difference in } \\
\text { mainstem } \\
\text { streamflow, } \\
\text { minus } \\
\text { tributaries } \\
\left(\mathbf{f t}^{\mathbf{3}} / \mathrm{s}\right)\end{array}$ & $\begin{array}{c}\text { Specific } \\
\text { conductance } \\
(\mu \mathrm{S} / \mathrm{cm})\end{array}$ & Remarks \\
\hline Dripping Vat Spring & S1 & 0.05 & -- & 2,680 & -- \\
\hline Little Bighorn River & $\mathrm{S} 2$ & 70 & - & 359 & S, 06289000 \\
\hline Little Bighorn River & S3 & 102 & 32 & 497 & S, 06289500 \\
\hline Pass Creek & $\mathrm{S} 4$ & 22 & -- & 590 & S, 06290000 \\
\hline Little Bighorn River & S5 & 130 & 6 & 552 & -- \\
\hline Bozeman Trail Ditch & S6 & .2 & -- & -- & -- \\
\hline Little Bighorn River & S7 & 126 & (4) & 555 & S, 06290500 \\
\hline Little Bighorn River & S8 & 135 & 9 & 550 & -- \\
\hline Little Bighorn River & S9 & 129 & (6) & 563 & -- \\
\hline Owl Creek & S10 & 3.0 & -- & 840 & -- \\
\hline Little Bighorn River & S11 & 128 & (4) & 573 & $\mathrm{O}$ \\
\hline Little Bighorn River & S11 & 123 & -- & 565 & $\mathrm{O}$ \\
\hline Lodge Grass Canal No. 1 & $\mathrm{~S} 12$ & 10 & -- & 630 & -- \\
\hline Lodge Grass Creek & $\mathrm{S} 13$ & 17 & -- & 778 & - \\
\hline Little Bighorn River & $\mathrm{S} 14$ & 155 & 15 & 605 & -- \\
\hline Lodge Grass Canal No. 1 & $\mathrm{~S} 15$ & 3.3 & -- & 690 & -- \\
\hline Little Bighorn River & S16 & 160 & 2 & 608 & $\mathrm{O}$ \\
\hline Little Bighorn River & S16 & 162 & -- & 621 & $\mathrm{O}$ \\
\hline Little Bighorn River & S17 & 164 & 2 & 619 & -- \\
\hline Reno Canal & $\mathrm{S} 18$ & 6.2 & -- & 619 & -- \\
\hline Reno Canal & S19 & 2 & -- & 796 & -- \\
\hline Little Bighorn River & $\mathrm{S} 20$ & 157 & (3) & 708 & -- \\
\hline Agency Canal & $\mathrm{S} 21$ & .1 & -- & 678 & -- \\
\hline Little Bighorn River & $\mathrm{S} 22$ & 157 & 0 & 716 & -- \\
\hline Little Bighorn River & $\mathrm{S} 23$ & 153 & (4) & 694 & -- \\
\hline Little Bighorn River & $\mathrm{S} 24$ & 159 & 6 & 717 & -- \\
\hline Little Bighorn River & $\mathrm{S} 25$ & 157 & (2) & 753 & S, 06294000 \\
\hline Agency Canal & $\mathrm{S} 26$ & 1.3 & -- & 1,900 & -- \\
\hline
\end{tabular}




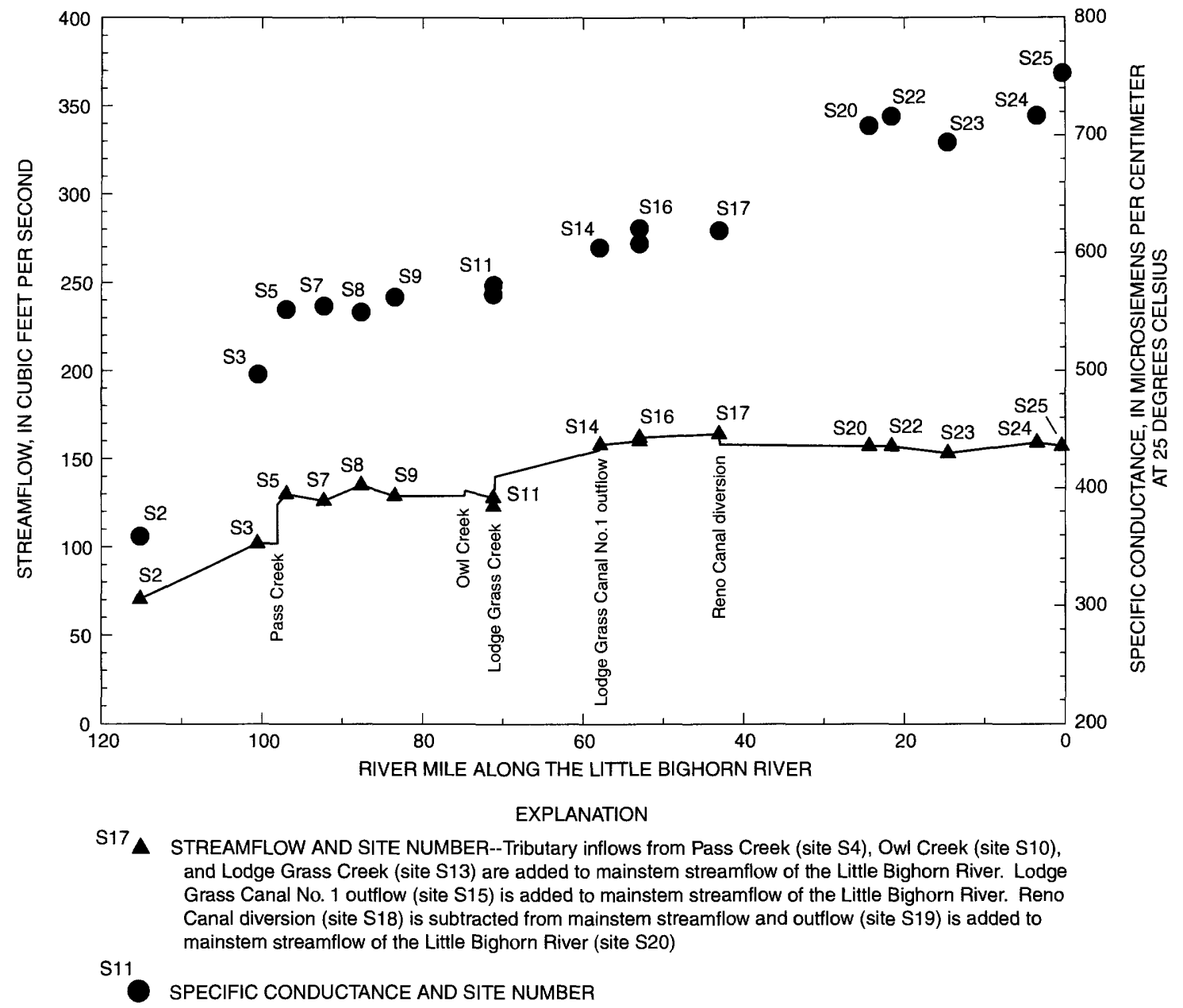

Figure 7. Synoptic-streamflow measurements and specific conductance of the Little Bighorn River, Montana, October $25,1994$.

October 1994. Second, from sites S11 to S16, streamflow increased by about $17 \mathrm{ft}^{3} / \mathrm{s}$, after subtracting tributary inflow from Lodge Grass Creek (site S13) and outflow from Lodge Grass Canal No. 1 (site S15). Some increase in streamflow likely can be attributed to unmeasured irrigation return flow. In addition, some increase in streamflow probably can be attributed to discharge from the Judith River

Formation, but the extent of the contribution could not be determined from available data. Thus, the quantity of water discharged from Quaternary alluvium and the Judith River Formation between sites S11 and S16 was less than $17 \mathrm{ft}^{3} / \mathrm{s}$ (less than $3.0 \mathrm{ft}^{3} / \mathrm{s}$ of water per mile) in October 1994.

Other reaches of the Little Bighorn River did not show substantial gains in streamflow from ground water. In addition, no reach showed any substantial loss of streamflow that might indicate recharge to the alluvium. Specific conductance generally increased gradually in a downstream direction.

Apparent small gains in streamflow at some mainstem sites were followed by apparent small losses at downstream sites. These apparent small gains or losses from site to site might represent measurement errors or changes in flow over time (unsteady flow) as a result of diurnal streamflow fluctuations. Streamflow records on the dates of the synoptic-streamflow measurements indicate that streamflow may have fluctuated over the time of measurement by as much as 10 $\mathrm{ft}^{3} / \mathrm{s}$ at sites S2, S7, and S25. As a result, mainstem streamflow changes less than about $10 \mathrm{ft}^{3} / \mathrm{s}$ may not represent gains or losses due to inflow or outflow, but 
rather changes due to unsteady flow conditions over the measurement period.

Overall, the synoptic measurements indicate an appreciable gain in streamflow between sites $\mathrm{S} 2$ and S5, no appreciable gain or loss between sites S5 and S11, an appreciable gain between sites S11 and S16, and no appreciable gain or loss between sites S16 and $\mathrm{S} 25$. The total gain, excluding surface-water inflows, indicated by the synoptic measurements was about 55 $\mathrm{ft}^{3} / \mathrm{s}$ (39,800 acre-ft/yr). This figure compares favorably with the overall gain indicated by the comparison of long-term streamflow records at sites S2, S4, S7, $\mathrm{S} 25$, and $\mathrm{S} 27$ of $45 \mathrm{ft}^{3} / \mathrm{s}$.

On the basis of the base-flow calculations from gage records (table 2) and the synoptic-streamflow investigation (table 3), gains in streamflow from ground water along the Little Bighorn River valley from site $S 2$ to site $S 25$ probably range from about 45 to $55 \mathrm{ft}^{3} / \mathrm{s}$. Thus, ground water was estimated to contribute from 15 to 18 percent of the annual daily mean streamflow (water year 1995) of the Little Bighorn River near Hardin (site S25; U.S. Geological Survey, 1996).

Indirect evidence indicates that the Quaternary alluvium and the underlying Judith River Formation are hydraulically connected. These hydrogeologic units seem to have similar hydraulic heads near Lodge Grass and near Garryowen and the Little Bighorn Battlefield National Monument (pl. 1). However, the potentiometric contours are not well defined because of a lack of water-level data.

Short-term changes in water levels in wells (fig. 8) also provide indirect evidence that the two aquifers are hydraulically connected in the area between Garryowen and the Little Bighorn Battlefield National Monument and are recharged, in part, by leakage from the Reno Canal. Figure 8 illustrates the similarity of seasonal variation in water levels in wells completed in the alluvium and the Judith River Formation. Water-level rises and declines are similar, indicating a hydraulic connection between the two aquifers.

\section{Water Quality}

Based on the laboratory analytical results for samples collected and from data compiled for this study, water in the Quaternary alluvium generally had relatively high concentrations of dissolved calcium, magnesium, sodium, bicarbonate, sulfate, chloride, and iron (pl. 1 and fig. 9). The major-ion composition was predominated by calcium, magnesium, and sodium cations, and bicarbonate and sulfate anions.

A distinctive characteristic of water from most alluvium was the generally high concentrations of dissolved solids (fig. 9), which commonly exceeded 1,000 $\mathrm{mg} / \mathrm{L}$. Dissolved-solids concentrations ranged from 264 to $4,770 \mathrm{mg} / \mathrm{L}$, with a median of $1,450 \mathrm{mg} / \mathrm{L}$ (table 7). The dissolved-solids concentrations generally were highest north of Crow Agency and just south of Lodge Grass (pl. 1). North of Crow Agency, the concentrations of dissolved solids might be high, in part, because Upper Cretaceous rocks underlie alluvium in this part of the study area. Water from marine shale within Upper Cretaceous rocks or interstitial sediment from this shale in the alluvium probably affects the water quality in alluvium (Moulder and others, 1960). South of Lodge Grass, the concentrations of dissolved solids in wells W131, W132, and W134 might be high, in part, because interbedded marine shale of the Judith River Formation affects the water quality in alluvium, and ground water probably is not recharged by the Little Bighorn River or irrigation.

The dissolved-solids concentrations in water from wells completed in alluvium generally were lower (less than 1,000 mg/L) along Lodge Grass Creek and southwest of Wyola (pl. 1). Wells near the Little Bighorn River (wells W7, W13, W42, W46, and W59) also have water with lower dissolved-solids concentrations. The low dissolved-solids concentrations in water from these wells probably indicate the effect of recharge from less mineralized water from the Little Bighorn River (median dissolved-solids concentrations of $179 \mathrm{mg} / \mathrm{L}$ at site $\mathrm{S} 2$ and $350 \mathrm{mg} / \mathrm{L}$ at site $\mathrm{S} 25)^{2}$, Lodge Grass Creek (median specific conductance of $510 \mu \mathrm{S} / \mathrm{cm})^{2}$, or water from irrigation.

Water-quality data were compared to primary and secondary drinking-water regulations of the U.S. Environmental Protection Agency (EPA) (2000). National primary drinking-water regulations are established for chemical constituents which, if present in drinking water, can cause adverse human health effects. Either a maximum contaminant level (MCL)

\footnotetext{
${ }^{2}$ Data retrieved from the USGS National Water Information System (NWIS), water years 1993-95.
} 


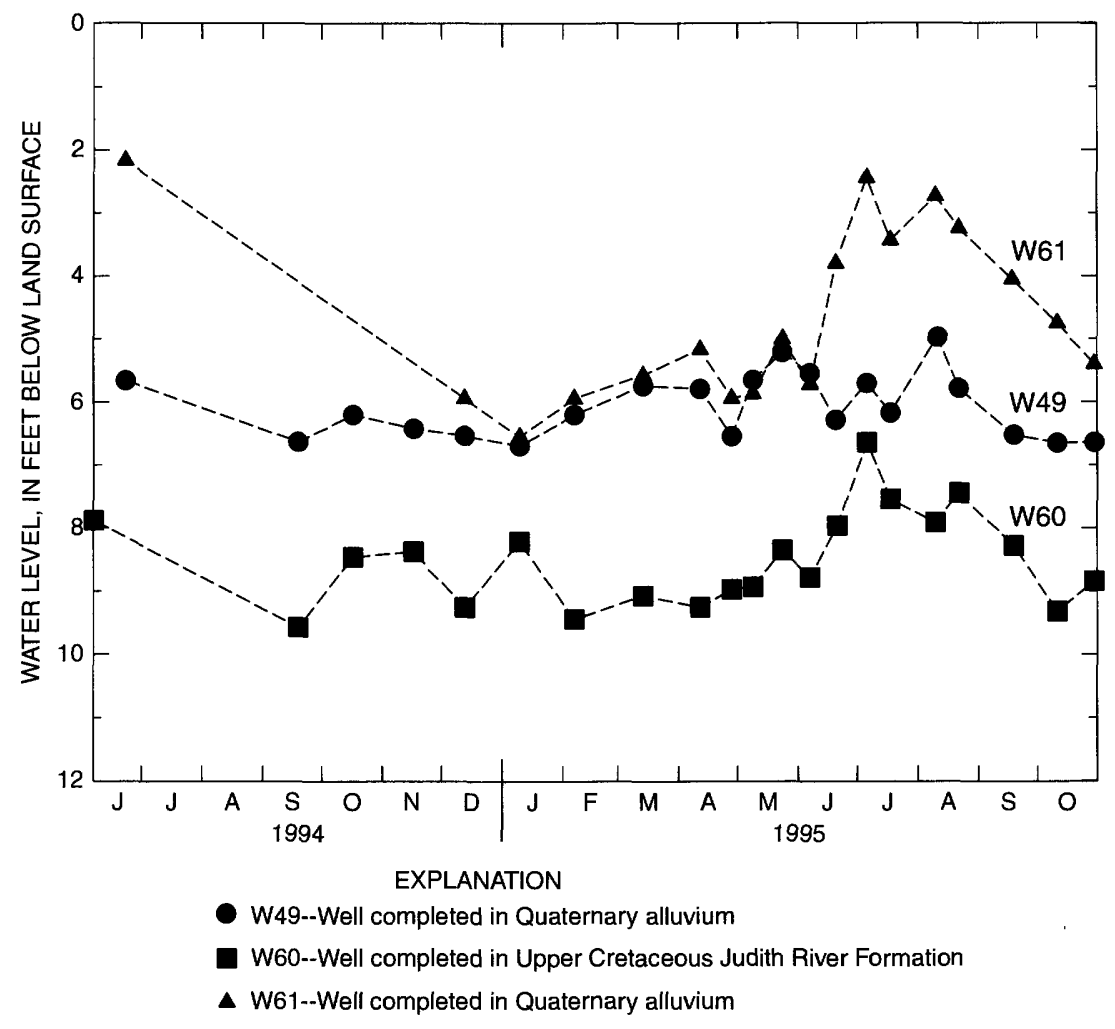

Figure 8. Seasonal variation in water levels in wells completed in Quaternary alluvium and the Upper Cretaceous Judith River Formation downgradient from the Reno Canal, Montana.

or a treatment technique is specified by these regulations. MCLs are health-based and enforceable for public drinking-water supplies. National secondary drinking-water regulations (SDWRs) are established for constituents or properties that can adversely affect the odor or appearance of water. These regulations are esthetically based and nonenforceable.

The chemical quality of water from the Quaternary alluvium (table 7) varied and, although widely used for domestic purposes, some water can pose a health risk for domestic use as defined by the EPA (2000) MCLs or was esthetically unsuitable as defined by the EPA SDWRs. Exceedances of the health-based MCLs were infrequent. The concentration of beryllium in water from three wells equaled or exceeded the MCL of $0.004 \mathrm{mg} / \mathrm{L}(4 \mu \mathrm{g} / \mathrm{L})$ and the concentration of radon in water from 10 wells exceeded the MCL of 300 $\mathrm{pCi} / \mathrm{L}$. Exceedances of the esthetically based SDWRs were more common with the concentration of sulfate in water from 39 wells exceeding the SDWR of 250 $\mathrm{mg} / \mathrm{L}$ and the concentration of dissolved solids in water from 39 wells exceeding the SDWR of $500 \mathrm{mg} / \mathrm{L}$. The iron SDWR of $0.3 \mathrm{mg} / \mathrm{L}(300 \mu \mathrm{g} / \mathrm{L})$ was equaled or exceeded in water from 14 wells, whereas the manganese SDWR of $0.05 \mathrm{mg} / \mathrm{L}(50 \mu \mathrm{g} / \mathrm{L})$ was equaled or exceeded in water from 16 wells.

Water from alluvium might not be suitable for some irrigation applications based on a comparison of specific conductance and the sodium-adsorption ratio (U.S. Salinity Laboratory Staff, 1954). Generally, the water has a medium to very high salinity hazard (specific conductance that ranges from 431 to $5,080 \mu \mathrm{S} / \mathrm{cm}$, table 4) and a low to very high sodium hazard (sodiumadsorption ratio that ranges from 0.5 to 26 , table 7 ).

\section{Upper Cretaceous Judith River Formation}

The Upper Cretaceous Judith River Formation crops out generally west of the Little Bighorn River and, in the southern part of the study area, west of Pass Creek (pl. 1). The formation dips gently to the south- 

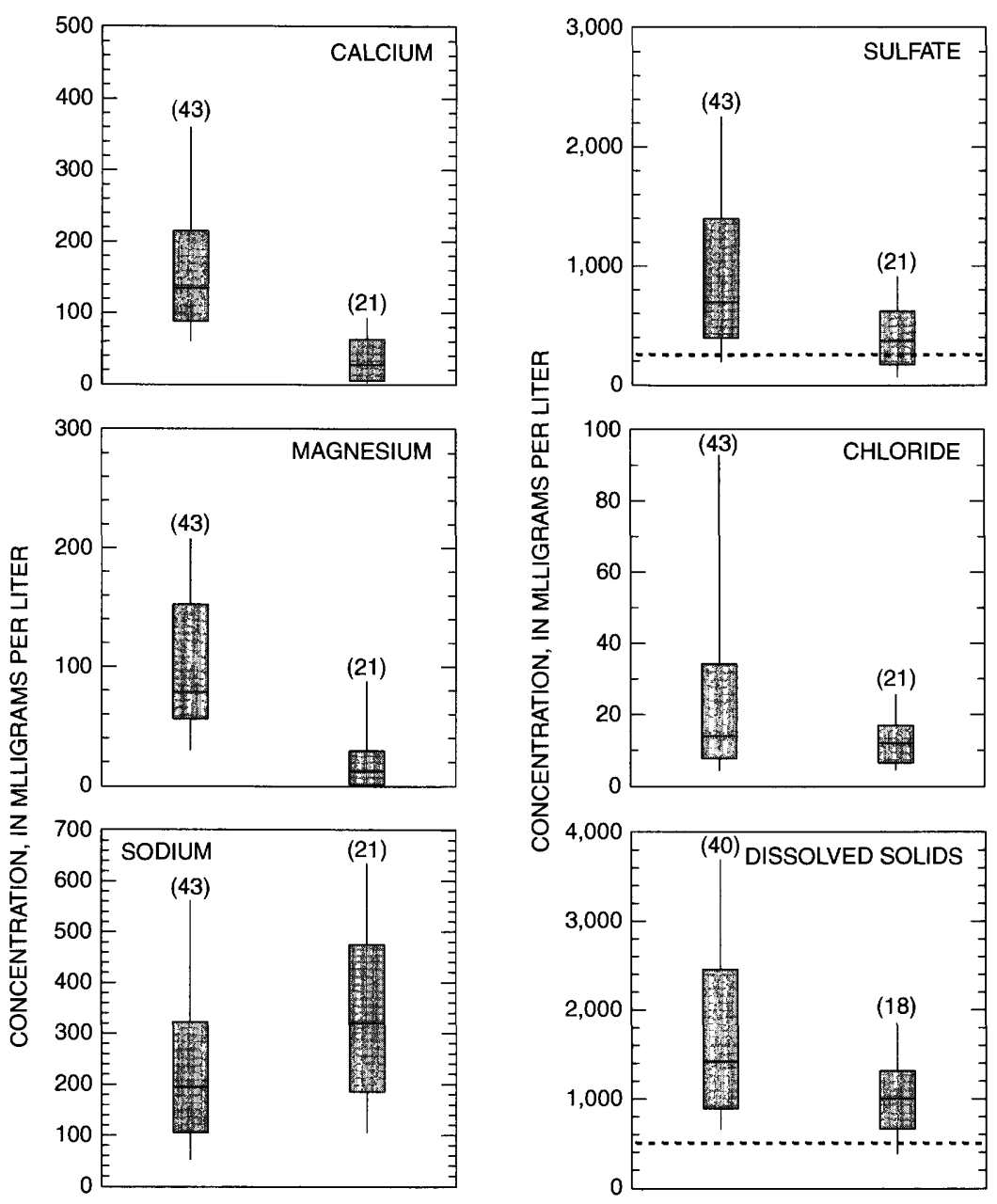

\section{EXPLANATION}

(43) Number of analyses

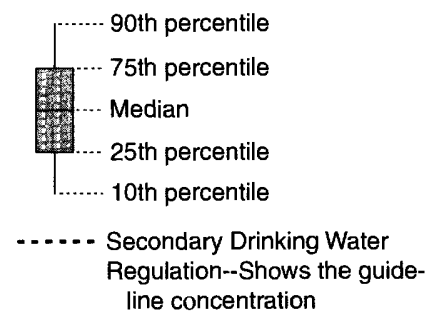

- Values for which percentiles are not calculated; insufficient number of analyses

Figure 9. Distribution of concentrations for selected chemical constituents in water from Quaternary alluvium and the Upper Cretaceous Judith River Formation along the Little Bighorn River and adjacent areas, Montana. To emphasize the central tendency of data, the upper and lower 10 percent of data have been excluded to eliminate outliers. 
east, east, and northeast owing to structural deformation associated with uplift of the Bighorn Mountains. Near the Montana-Wyoming boundary, the Judith River Formation includes an unnamed upper member composed of about $700 \mathrm{ft}$ of sandstone interbedded with sandy shale and shale. The lower member, the Parkman Sandstone Member, is composed of as much as $350 \mathrm{ft}$ of massive sandstone and sandy shale. Near Hardin, the Parkman Sandstone Member is $255 \mathrm{ft}$ thick (Richards, 1955; Knechtel and Patterson, 1956).

On the basis of information from drillers' logs about static-water levels and top of the probable waterbearing zone in wells, water in the Judith River Formation can be confined, unconfined, or leaky-confined. In recharge areas, located mostly along the terraces west of the Little Bighorn River and Pass Creek, this hydrogeologic unit probably is unconfined. Along the Little Bighorn River valley and Pass Creek, the Judith River Formation underlies the alluvium, which probably forms a leaky-confining layer. Several thousand feet of fine-grained, generally low-permeable Upper Cretaceous sandstone and shale underlie the Judith River Formation.

Aquifer tests conducted at two wells completed in the Judith River Formation as part of a previous reconnaissance investigation (Moulder and others, 1960) yielded estimates of hydraulic conductivity of about 8 and $50 \mathrm{ft} / \mathrm{d}$, transmissivity of 780 and 2,700 $\mathrm{ft}^{2} / \mathrm{d}$, and a storage coefficient of 0.0005 . In this study, the specific capacity of wells (table 6) completed in the Judith River Formation ranged from 0.06 to 7.4 (gal $/ \mathrm{min}) / \mathrm{ft}$, with a median of $0.41(\mathrm{gal} / \mathrm{min}) / \mathrm{ft}$. Transmissivity estimates from specific-capacity tests ranged from 39 to $780 \mathrm{ft}^{2} / \mathrm{d}$, with a median of $310 \mathrm{ft}^{2} / \mathrm{d}$ and an average of $350 \mathrm{ft}^{2} / \mathrm{d}$. Reported well yields from the Judith River Formation ranged from 5 to $74 \mathrm{gal} / \mathrm{min}$, with a median of about $10 \mathrm{gal} / \mathrm{min}$. After pumping at relatively low rates (less than about $12 \mathrm{gal} / \mathrm{min}$ ) water levels in many wells fall below the top of the waterbearing zone, resulting in unconfined conditions at the well (table 6). Low hydraulic conductivity and transmissivity, low specific capacities, and low well yields are typical of the Judith River Formation, where interbedded shale and fine-grained sandstone can be lenticularly bedded and laterally discontinuous (Richards, 1955; Knechtel and Patterson, 1956).

The direction of water movement in the Judith River Formation can be determined from the potentio- metric surface shown in plate 1 . The direction of water flow generally is from outcrop and subcrop areas west of the Little Bighorn River to the Little Bighorn River where water discharges to the Quaternary alluvium or the river. South of Wyola, water flows from outcrop and subcrop areas to the Little Bighorn River or Pass Creek, where the Judith River Formation might discharge to alluvium. The gradient of the potentiometric surface varies. Near Wyola, the gradient is about 0.006 ( $33 \mathrm{ft} / \mathrm{mi})$. Near Lodge Grass, the gradient is steep near the recharge area northwest of Lodge Grass and is $0.02(120 \mathrm{ft} / \mathrm{mi})$, but decreases near the river to 0.004 (21 ft/mi). West of Reno Creek, the gradient is steep and is about $0.02(80 \mathrm{ft} / \mathrm{mi})$, but decreases to about $0.005(29 \mathrm{ft} / \mathrm{mi})$ along the river near the Little Bighorn Battlefield National Monument.

\section{Recharge}

Estimates of recharge and discharge components (developed as part of this study) for the Judith River Formation are summarized in table 1. Because of the large areal extent of the Judith River Formation, the ground- and surface-water interactions, and the complexity of interactions with Quaternary alluvium and the Little Bighorn River, accurately determining some of the components of recharge and discharge is beyond the scope of this study. Therefore, these components are discussed only qualitatively. No attempt was made to balance recharge and discharge components in a hydrologic budget. However, recharge and discharge estimates could be used as a conceptual model for water flow in the Judith River Formation.

Recharge to the Judith River Formation is by infiltration and subsequent percolation of precipitation, infiltration of streamflow across outcrops, canal leakage, bank storage, and by subsurface inflow from Quaternary high-terrace deposits. Infiltration and subsequent percolation of precipitation typically recharge the Judith River Formation during the fall and winter before the ground freezes, and early spring when evapotranspiration is minimal. On the basis of the average precipitation in the study area from October through April of 6.7 in. (Western Regional Climate Center, 2001) over an area of about $75 \mathrm{mi}^{2}$ of outcrop and subcrop (below Quaternary high-terrace deposits), recharge from precipitation cannot be more than about 26,900 acre-ft/yr. Actual recharge from precipitation probably is substantially less than this quantity because some of this precipitation will evaporate, sublimate, 
transpire, run off, or be retained as soil moisture. Some of this recharge from infiltration and subsequent percolation of precipitation (fig. 3) occurs as subsurface inflow from Quaternary high-terrace deposits where these deposits overlie the Judith River (pl. 1).

Water-level rises in some wells during the fall, winter, and spring (fig. 4; for example, wells W65, $\mathrm{W} 68, \mathrm{~W} 102, \mathrm{~W} 122$, and $\mathrm{W} 153$ ) probably result from a combination of precipitation recharge before the ground freezes or after it thaws, infiltration of streamflow across outcrops, and subsurface inflow from Quaternary high-terrace deposits. Above-normal precipitation during some months in 1995 (fig. 3) in the study area (Western Regional Climate Center, 2001) probably caused water levels in some wells, in part, to have an overall increasing trend during the summer of 1995 (fig. 4; wells W65, W68, and W102). However, precipitation from about May through September probably does not substantially recharge the Judith River Formation because evapotranspiration by crops and natural vegetation typically exceeds precipitation in the study area during the growing season in most years (Moulder and others, 1960; Toy and Munson, 1978).

The quantity of recharge to the Judith River Formation by canal leakage also is unknown. However, Moulder and others, (1960) estimated an average leakage rate of $0.00038 \mathrm{ft}^{3} / \mathrm{s}$ in alluvium. Recharge by canal leakage would recharge the Judith River where canals extend along outcrops, generally between Lodge Grass and Crow Agency (fig. 4, for example wells W60, W102, and W110).

The quantity of recharge to the Judith River Formation by infiltration of bank storage during high streamflow is unknown, but probably is limited along the Little Bighorn River because of minimal areas where the river intersects the formation. Figure 4 shows water-level rises in well W153 due, in part, to rising stage of the Little Bighorn River. Moulder and others (1960) determined that well W45 (not shown in fig. 4) also is affected by stage in the Little Bighorn River. The Judith River Formation probably is hydraulically connected to the Little Bighorn River where it crops out or subcrops near the river.

\section{Discharge}

Discharge from the Judith River Formation is primarily through upward subsurface outflow to Quaternary alluvium and the Little Bighorn River, withdrawals from wells, and evapotranspiration. Discharge by subsurface outflow to alluvium and the Little Bighorn River is estimated to range from 175 to 1,750 acre-ft/yr (table 1). This estimate was based on Darcy's Law (equation 3) using an areal extent of 24,900 acres $\left(39 \mathrm{mi}^{2}\right)$ where the Judith River Formation underlies alluvium, a vertical gradient of 0.07 determined from wells W47 and W48, and a vertical hydraulic conductivity that ranges from 0.1 to $1.0 \mathrm{ft} / \mathrm{d}$. An assumption of the calculation is that vertical gradients are the same throughout the study area and that the vertical hydraulic conductivity is about an order of magnitude less than the horizontal hydraulic conductivity (about 8 and $50 \mathrm{ft}^{2} / \mathrm{d}$; Moulder and others, 1960). However, vertical gradients and vertical hydraulic conductivities probably vary throughout the study area.

Water in the Judith River Formation is primarily used for either commercial, domestic, or stock-watering purposes. Water from the Judith River Formation is not used for irrigation. Withdrawals from wells for domestic use for the entire study area was estimated to be about 260 acre-ft/yr (see section on "Quaternary alluvium"). The Judith River Formation underlies about $39 \mathrm{mi}^{2}$ of alluvium and in these areas both aquifers are used for domestic and stock-watering purposes. The Judith River Formation also is extensively used as a source of domestic and stock-watering supplies where it exists outside of the alluvial valley and in Lodge Grass. Withdrawals from wells for stock-watering purposes is unknown but is assumed to be small because surface water from the river and canals is used extensively for stock watering along the alluvial valley. An estimate of withdrawals from wells from the Judith River Formation is difficult to calculate because of lack of data, but the quantity is most likely less than one-half of the total estimated for domestic use (table 1).

The quantity of discharge from the Judith River Formation by evapotranspiration cannot be estimated from available data. Along the terraces west of the Little Bighorn River and Pass Creek, dryland wheat and native grass grow on Judith River Formation outcrops. Evapotranspiration rates for dryland wheat and native grass range from 1.7 to $1.9 \mathrm{ft}$ per year (Toy and Munson, 1978), which is greater than the average annual precipitation of about $14.9 \mathrm{in}$. for the study area (Western Regional Climate Center, 2001). The difference between evapotranspiration and average annual precipitation results in a plant-water deficit that requires plants to supplement soil moisture with available ground water in most years. Where the Judith River Formation crops out and the depth to water is less than 
about $15 \mathrm{ft}$, water probably is directly discharged by evapotranspiration. In subcrop areas, recharge from Quaternary high-terrace deposits probably is reduced because water is discharged by evapotranspiration from this hydrogeologic unit. Generally, from March through October 1995, above normal precipitation (fig. 3 ) in the study area (Western Regional Climate Center, 2001) caused water levels in some wells completed in the Judith River Formation (fig. 4, for example wells W65 and W68), to have an overall increasing trend; thus, recharge was greater than discharge during the 1995 growing season.

\section{Water Quality}

Based on the laboratory analytical results from samples collected and from data compiled for this study, the major-ion composition of most water in the Judith River Formation was predominated by the sodium cation and the bicarbonate and sulfate anions (pl. 1 and fig. 9). Water from four wells (W65, W85, W102, and W167) was a sodium bicarbonate type, whereas water from two wells (W43 and W160) contained a mixture of magnesium, sodium, and calcium cations and bicarbonate or sulfate anions. Water from wells W43 and W160 was an anomalous water type for the Judith River Formation in the study area because sodium was not the predominant cation. Water from these two wells probably was recharged from either the Reno Canal (well W43) or the Little Bighorn River (well W160). If water from well W160 was recharged primarily from the Little Bighorn River, then the local gradient may trend laterally to the east; thus, the Judith River Formation might not discharge to Quaternary alluvium and the Little Bighorn River in the area near well W160.

Dissolved-solids concentrations in water from the Judith River Formation ranged from 352 to 1,910 $\mathrm{mg} / \mathrm{L}$, with a median of $1,000 \mathrm{mg} / \mathrm{L}$. Water from the Judith River Formation generally had a dissolved-solids concentration greater than $1,000 \mathrm{mg} / \mathrm{L}$ between Reno Creek and the Little Bighorn Battlefield National Monument (except for wells W64 and W65). The larger dissolved solids in water from this area might reflect the effect of interbedded marine shale in the Judith River Formation. Water from the Judith River Formation generally had a dissolved-solids concentration less than 1,000 mg/L between Wyola and Benteen. The area between Wyola and Benteen coincides with the location of more massive sandstone outcrops of the
Judith River Formation along the Little Bighorn River and might indicate the effect of recharge of less mineralized water (median dissolved-solids concentrations of $179 \mathrm{mg} / \mathrm{L}$ at site $\mathrm{S} 2$ and $350 \mathrm{mg} / \mathrm{L}$ at site $\mathrm{S} 25$ ) from the river or irrigation.

The chemical quality of water from the Judith River Formation (table 7) varied and is probably suitable for most domestic uses. Although none of the sampled wells had water with constituent concentrations that exceeded the health-based EPA MCLs, several SDWRs (U.S. Environmental Protection Agency, 2000) were exceeded that may render the water esthetically unsuitable for various uses. The concentration of sulfate in water from 14 wells exceeded the SDWR of $250 \mathrm{mg} / \mathrm{L}$ and the concentration of dissolved solids in water from 16 wells exceeded the SDWR of $500 \mathrm{mg} / \mathrm{L}$. The iron SDWR of $0.3 \mathrm{mg} / \mathrm{L}(300 \mu \mathrm{g} / \mathrm{L})$ was exceeded in water from 10 wells, whereas concentration of manganese in water from 6 wells exceeded the SDWR of $0.05 \mathrm{mg} / \mathrm{L}(50 \mu \mathrm{g} / \mathrm{L})$.

Water from the Judith River Formation might not be suitable for some irrigation applications based on a comparison of specific conductance and the sodiumadsorption ratio (U.S. Salinity Laboratory Staff, 1954). Generally, the water has a high to very high salinity hazard (specific conductance ranges from 880 to 4,470 $\mu \mathrm{S} / \mathrm{cm}$; table 4 ) and a low to very high sodium hazard (sodium-adsorption ratio ranges from 0.8 to 82 , table 7).

\section{SUMMARY}

Water from the Quaternary alluvium and the Upper Cretaceous Judith River Formation is the primary source for domestic and stock supplies. Shallow ground water (less than about $100 \mathrm{ft}$ below land surface) generally is not available for domestic and stock use in areas where alluvium or the Judith River Formation do not exist. This report describes the general geology and the water resources of the Quaternary alluvium and the Upper Cretaceous Judith River Formation along the Little Bighorn River within the Crow Indian Reservation of southeastern Montana. Data were collected and compiled for 193 ground-water and 27 surface-water sites.

Quaternary alluvium underlies an area of about $94 \mathrm{mi}^{2}$ located primarily along the Little Bighorn River and its major perennial tributaries, Lodge Grass and Pass Creeks. Quaternary alluvium is composed of unconsolidated gravel, sand, silt, and clay that gener- 
ally have a combined thickness of less than about $30 \mathrm{ft}$. Thickness of the probable water-bearing zone within the alluvium ranges from 2 to $39 \mathrm{ft}$, with a median of 9 $\mathrm{ft}$. The specific capacity of wells completed in Quaternary alluvium ranged from 0.31 to $30(\mathrm{gal} / \mathrm{min}) / \mathrm{ft}$, transmissivity ranged from 230 to $6,900 \mathrm{ft}^{2} / \mathrm{d}$, and well yields ranged from 4 to $50 \mathrm{gal} / \mathrm{min}$. Low transmissivity, low specific capacity, and low well yield are typical of alluvium deposited by rivers having a small carrying and sorting capacity, which results in deposits containing substantial quantities of fine-grained material. In addition, these deposits might also contain discontinuous or poorly connected lenses of coarser-grained material.

Recharge to Quaternary alluvium is by infiltration and subsequent percolation of precipitation, canal leakage, excess applied irrigation water, bank storage, and by subsurface inflow from alluvium in small ephemeral tributaries adjacent to the Little Bighorn valley and from the underlying Judith River Formation. Discharge from Quaternary alluvium is primarily through evapotranspiration, withdrawals from wells, flow to irrigation drains, and subsurface outflow to the Little Bighorn River. Ground water was estimated to contribute about 15 to 18 percent of the annual daily mean streamflow (in water year 1995) of the Little Bighorn River near Hardin.

Water in Quaternary alluvium generally had high concentrations of dissolved calcium, magnesium, sodium, bicarbonate, sulfate, chloride, and iron. The major-ion composition was predominated by calcium, magnesium, and sodium cations, and bicarbonate and sulfate anions. Dissolved-solids concentrations ranged from 264 to $4,770 \mathrm{mg} / \mathrm{L}$, with a median of $1,450 \mathrm{mg} / \mathrm{L}$. The dissolved-solids concentrations might be high, in part, because Upper Cretaceous rocks underlie and probably affect the water quality in alluvium. The lower dissolved-solids concentrations probably indicate the effect of recharge of less mineralized water from the Little Bighorn River, Lodge Grass Creek, or water from irrigation. The chemical quality of water from alluvium varied and some water can pose a health risk for domestic use.

The Upper Cretaceous Judith River Formation contains an unnamed upper member composed of about $700 \mathrm{ft}$ of sandstone interbedded with sandy shale and shale. The lower member, the Parkman Sandstone Member, is composed of as much as $350 \mathrm{ft}$ of massive sandstone and sandy shale. Specific capacity of wells completed in the Judith River Formation ranged from
0.06 to 7.4 (gal $/ \mathrm{min}) / \mathrm{ft}$, transmissivity estimates from specific-capacity tests ranged from 39 to $780 \mathrm{ft}^{2} / \mathrm{d}$, and well yields ranged from 5 to $74 \mathrm{gal} / \mathrm{min}$. Low transmissivity, low specific capacity, and low well yield are typical of the upper part of the Judith River Formation, where interbedded shale and fine-grained sandstone can be lenticularly bedded and laterally discontinuous. The lower part of the Judith River Formation (Parkman Sandstone Member) is a fine-grained sandstone that is massive locally, but also is not uniform throughout the study area.

Recharge to the Judith River Formation is by infiltration and subsequent percolation of precipitation, infiltration of streamflow across outcrops, canal leakage, bank storage, and by subsurface inflow from Quaternary high-terrace deposits. Discharge from the Judith River Formation is primarily through upward subsurface outflow to Quaternary alluvium and the Little Bighorn River, withdrawals from wells, and evapotranspiration.

The major-ion composition of most water in the Judith River Formation was predominated by the sodium cation and the bicarbonate and sulfate anions. Dissolved-solids concentrations in water from the Judith River Formation ranged from 352 to $1,910 \mathrm{mg} / \mathrm{L}$, with a median of $1,000 \mathrm{mg} / \mathrm{L}$. Water from the Judith River Formation generally had a dissolved-solids concentration greater than $1,000 \mathrm{mg} / \mathrm{L}$ between Reno Creek and the Little Bighorn Battlefield National Monument. The larger dissolved-solids in water from this area might reflect more interbedded marine shale and sandy shale in the Judith River Formation. Water from the Judith River Formation generally had a dissolved-solids concentration less than $1,000 \mathrm{mg} / \mathrm{L}$ between Wyola and Benteen, which might indicate the effect of recharge of less mineralized water from the Little Bighorn River or irrigation. The chemical quality of water from the Judith River Formation varied and is probably suitable for most domestic use.

\section{REFERENCES CITED}

Agard, S.S., 1989, Map showing Quaternary and late Tertiary terraces of the lower Bighorn River, Montana: U.S. Geological Survey Miscellaneous Field Studies Map MF-2094, scale 1:100,000.

Bergantino, R.N., comp., 1980, Geologic map of the Hardin $1^{\circ} \times 2^{\circ}$ quadrangle, southeastern Montana: Montana Bureau of Mines and Geology Montana Atlas 2-A, scale 1:250,000. 
Dollhopf, D.J., Wendt, G.W., Goering, J.D., and Hedberg, D.W., 1979, Hydrogeology of a watershed with subirrigated alluvial materials in crop productions. I. Mined land reclamation: Montana Agricultural Experiment Station, Reclamation Research Program Bulletin 715, 76 p.

Feltis, R.D., 1980, Dissolved-solids and ratio maps of water in the Madison Group, Montana: Montana Bureau of Mines and Geology Hydrogeologic Map 3, scale 1:1,000,000.

Flores, R.M., and Ethridge, F.G., 1985, Evolution of intermontane fluvial systems of Tertiary Powder River Basin, Montana and Wyoming, in Flores, R.M., and Kaplan, S.S., eds., Cenozoic paleogeography of the West-Central United States, Rocky Mountain Paleogeography Symposium 3, Rocky Mountain Section: Denver, Colo., Society of Economic Paleontologists and Mineralogists, $\mathrm{p}$. 107-126.

Glaze, R.E., and Keller, E.R., 1965, Geologic history of the Powder River Basin: American Association of Petroleum Geologists Bulletin, v. 49, part 2, no. 11, p. 1893-1907.

Heath, R.C., 1983, Basic ground-water hydrology: U.S. Geological Survey Water-Supply Paper 2220 , $84 \mathrm{p}$.

Kanizay, S.P., 1986a, Preliminary geologic map of the Lodge Grass area, northwestern Powder River Basin, Montana and Wyoming: U.S. Geological Survey Miscellaneous Field Studies Map MF1822, scale 1:50,000.

Kanizay, S.P., 1986b, Preliminary geologic map of the Crow Agency area, northwestern Powder River Basin, Montana: U.S. Geological Survey Miscellaneous Field Studies Map MF-1861, scale 1:50,000.

Knapton, J.R., 1985, Field guidelines for the collection, treatment, and analysis of water samples, Montana District: U.S. Geological Survey Open-File Report 85-409, 86 p.

Knechtel, M.M., and Patterson, S.H., 1956, Bentonite deposits in marine Cretaceous formations, Hardin District, Montana and Wyoming, with a section on Laboratory procedures used for testing the bentonites: U.S. Geological Survey Bulletin 1023, $116 \mathrm{p}$.

Lewis, B.D., and Roberts, R.S., 1978, Geology and water-yielding characteristics of rocks of the northern Powder River Basin, southeastern Montana: U.S. Geological Survey Miscellaneous Investigations Map I-847-D, scale 1:250,000.
Montana Department of Commerce, 2003, Census 2000, accessed May 29, 2003 at http:// ceic.commerce.state.mt.us.

Montana Department of Natural Resources and Conservation, 1986, Montana water use in 1980: Helena, $49 \mathrm{p}$.

Moulder, E.A., Klug, M.F., Morris, D.A., and Swenson, F.A., 1960, Geology and ground-water resources of the lower Little Bighorn River Valley, Big Horn County, Montana, with a special reference to the drainage of waterlogged lands, with a section on Chemical quality of the water, by R.A. Krieger: U.S. Geological Survey WaterSupply Paper 1487, 223 p.

Rantz, S.E., and others, 1982, Measurement and computation of streamflow: U.S. Geological Survey Water-Supply Paper 2175, 2 v., 631 p.

Richards, P.W., 1955, Geology of the Bighorn CanyonHardin area, Montana and Wyoming: U.S. Geological Survey Bulletin 1026, 93 p.

Thom, W.T., Jr., Hall, G.M., Wegeman, C.H., and Moulton, G.F., 1935, Geology of Bighorn County and the Crow Indian Reservation, Montana: U.S. Geological Survey Bulletin 856, 200 p.

Toy, T.J., and Munson, B.E., 1978, Climate appraisal maps of the rehabilitation potential of strippable coal lands in the Powder River Basin, Wyoming and Montana: U.S. Geological Survey Miscellaneous Studies Map MF-932, scale 1:500,000.

U.S. Environmental Protection Agency, 2000, Drinking water standards and health advisories: Office of Water, EPA 822-B-00-001, accessed January 3, 2001, at http://www.epa.gov/ost/ drinking/standards/summary.html.

U.S. Geological Survey, 1996, Water resources data, Montana, water year 1995: U.S. Geological Survey Water-Data Report MT-95-1, 521 p.

U.S. Salinity Laboratory Staff, 1954, Diagnosis and improvement of saline and alkali soils: U.S. Department of Agriculture Handbook 60,160 p.

Western Regional Climate Center, 2001, Montana climate summaries, Hardin and Wyola $1 \mathrm{SW}$ : accessed January 25, 2001, at http:// www.wrcc.dri.edu/summary/climsmmt.html 
DATA 


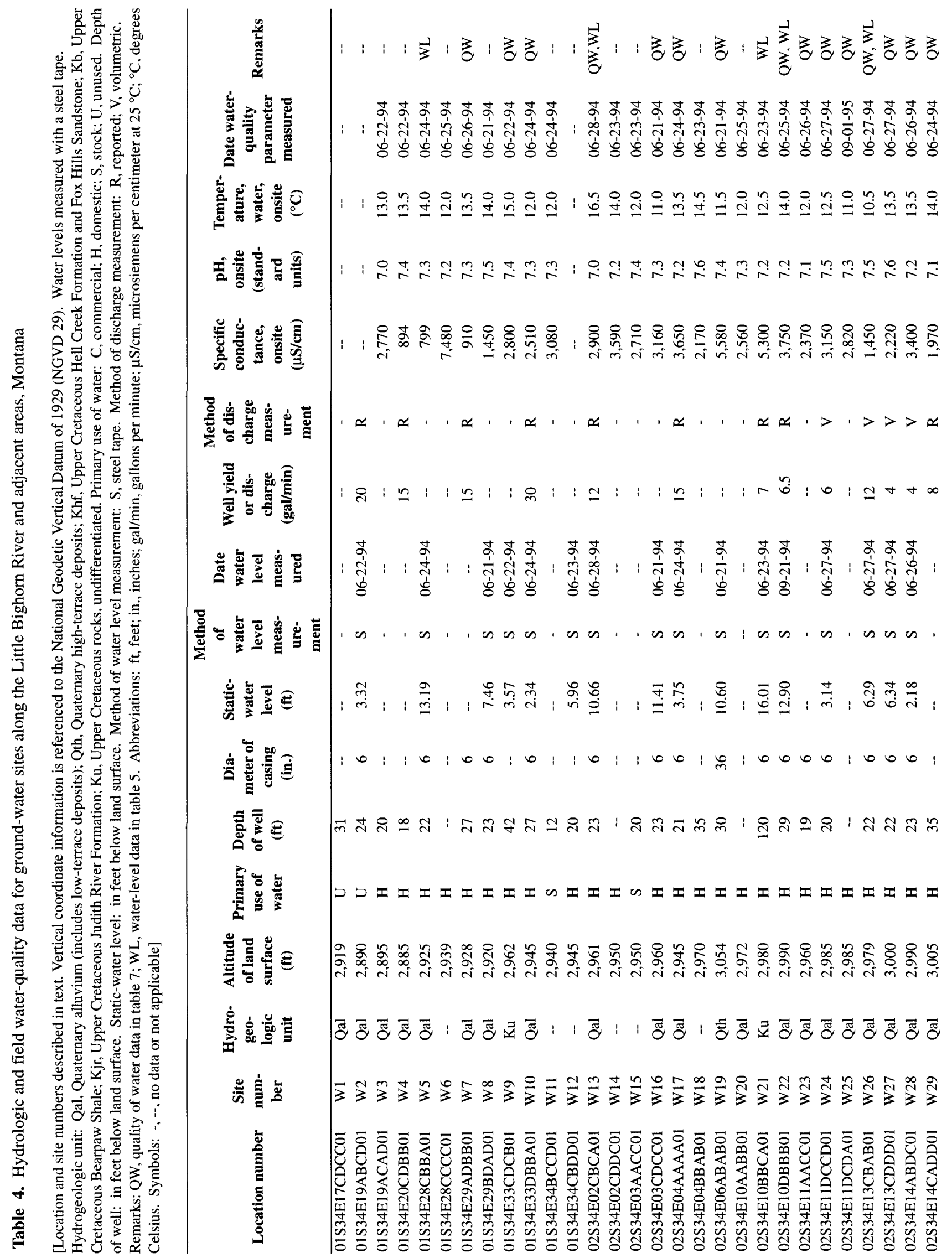




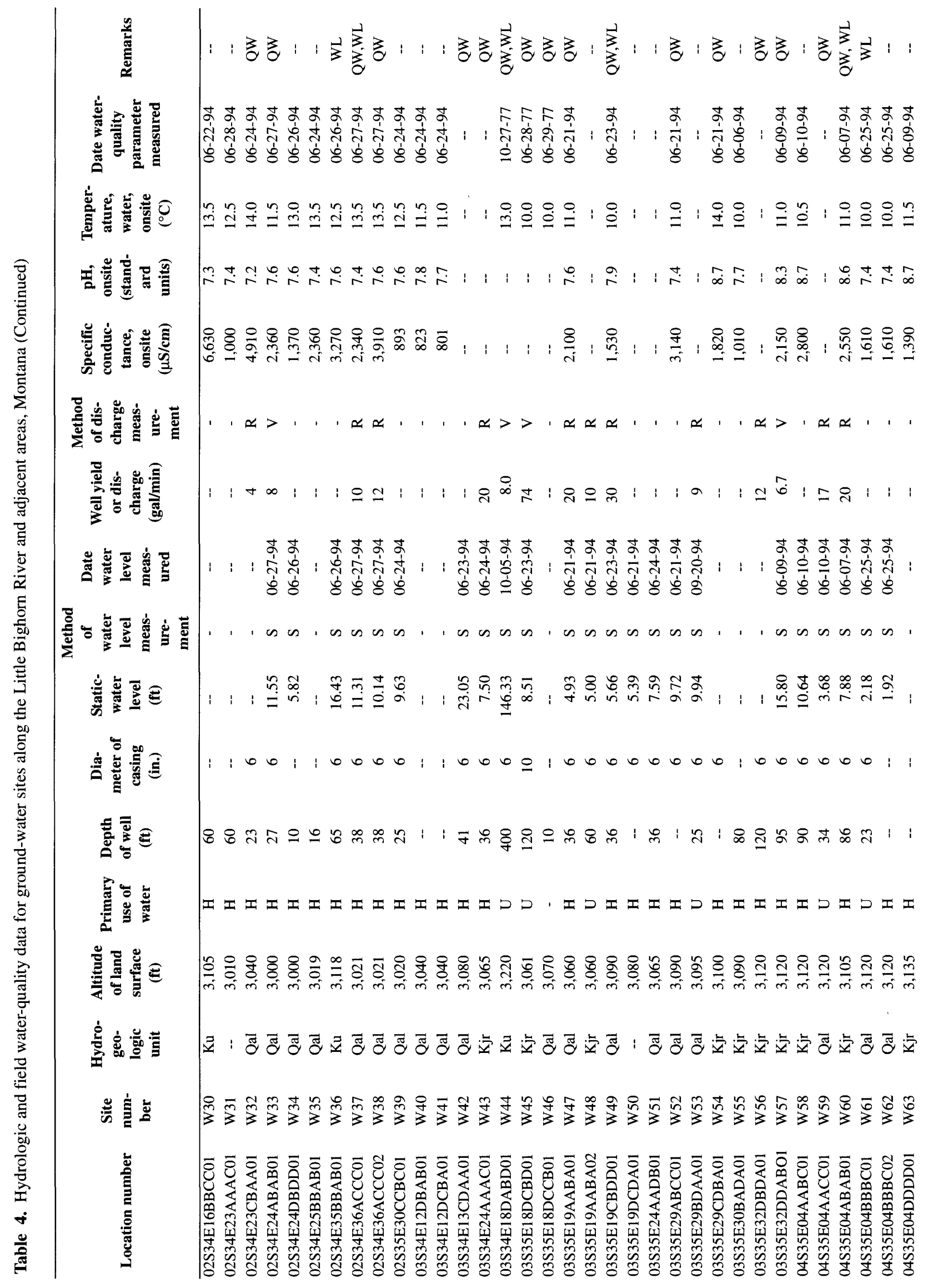




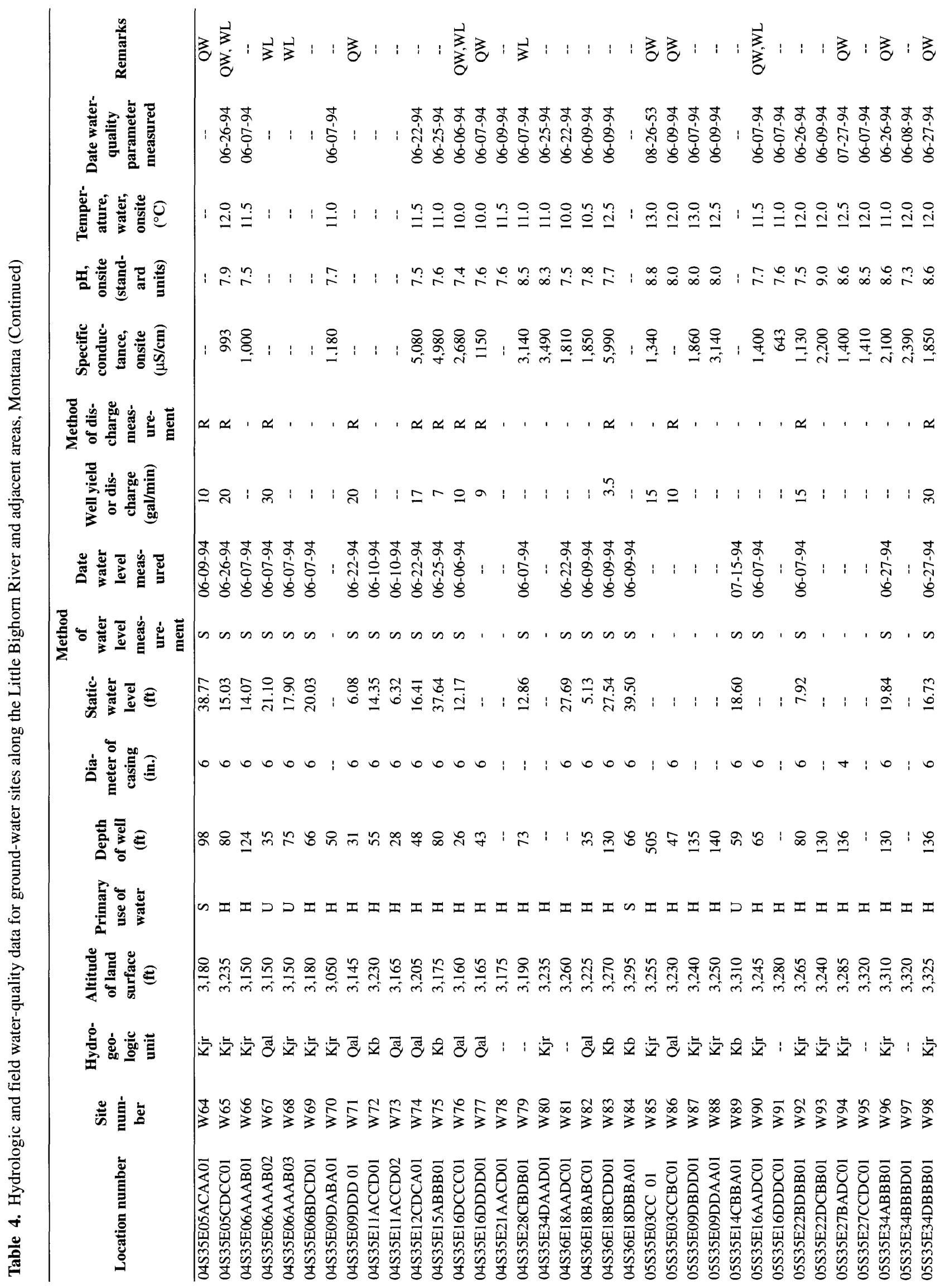




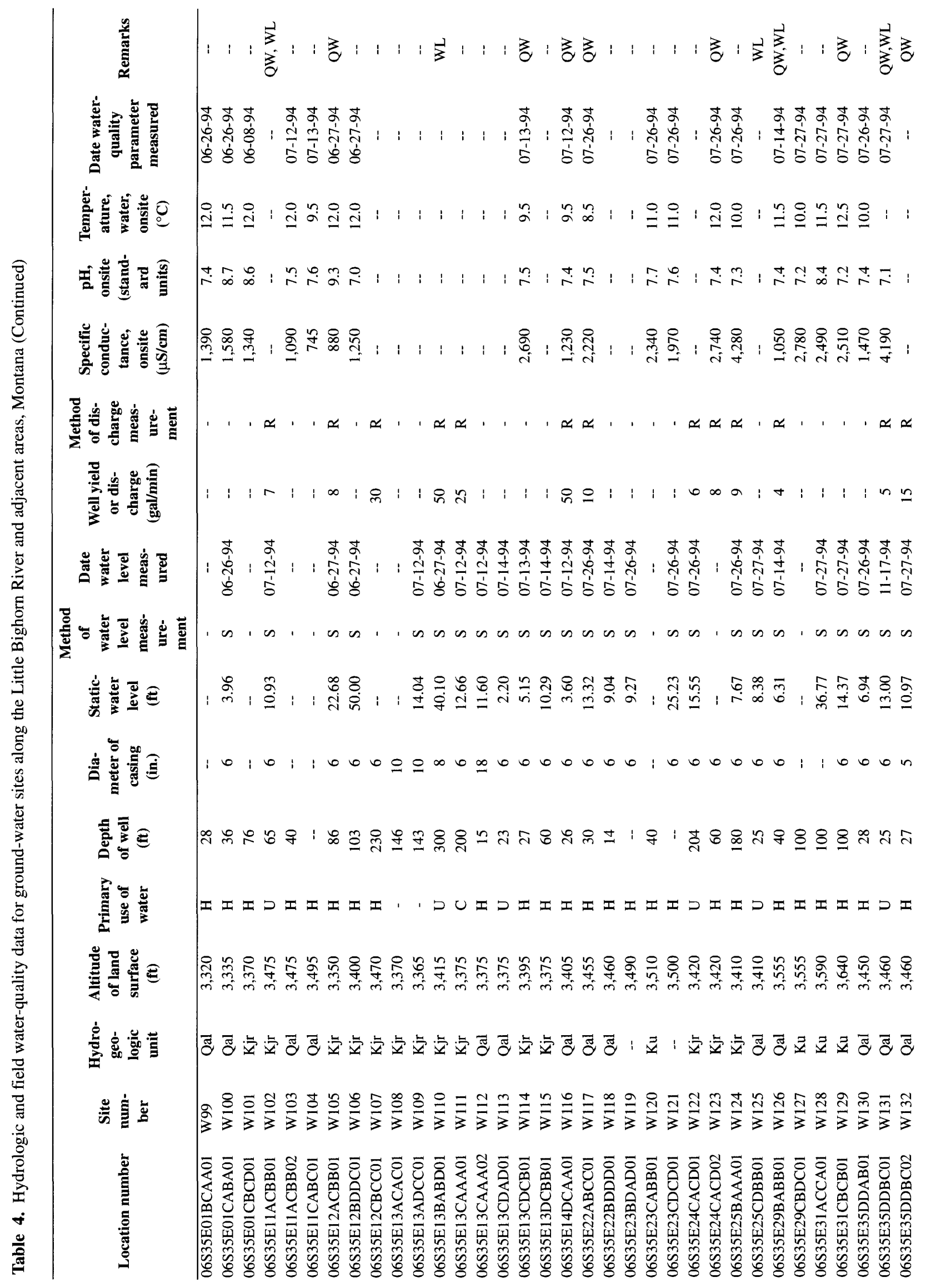




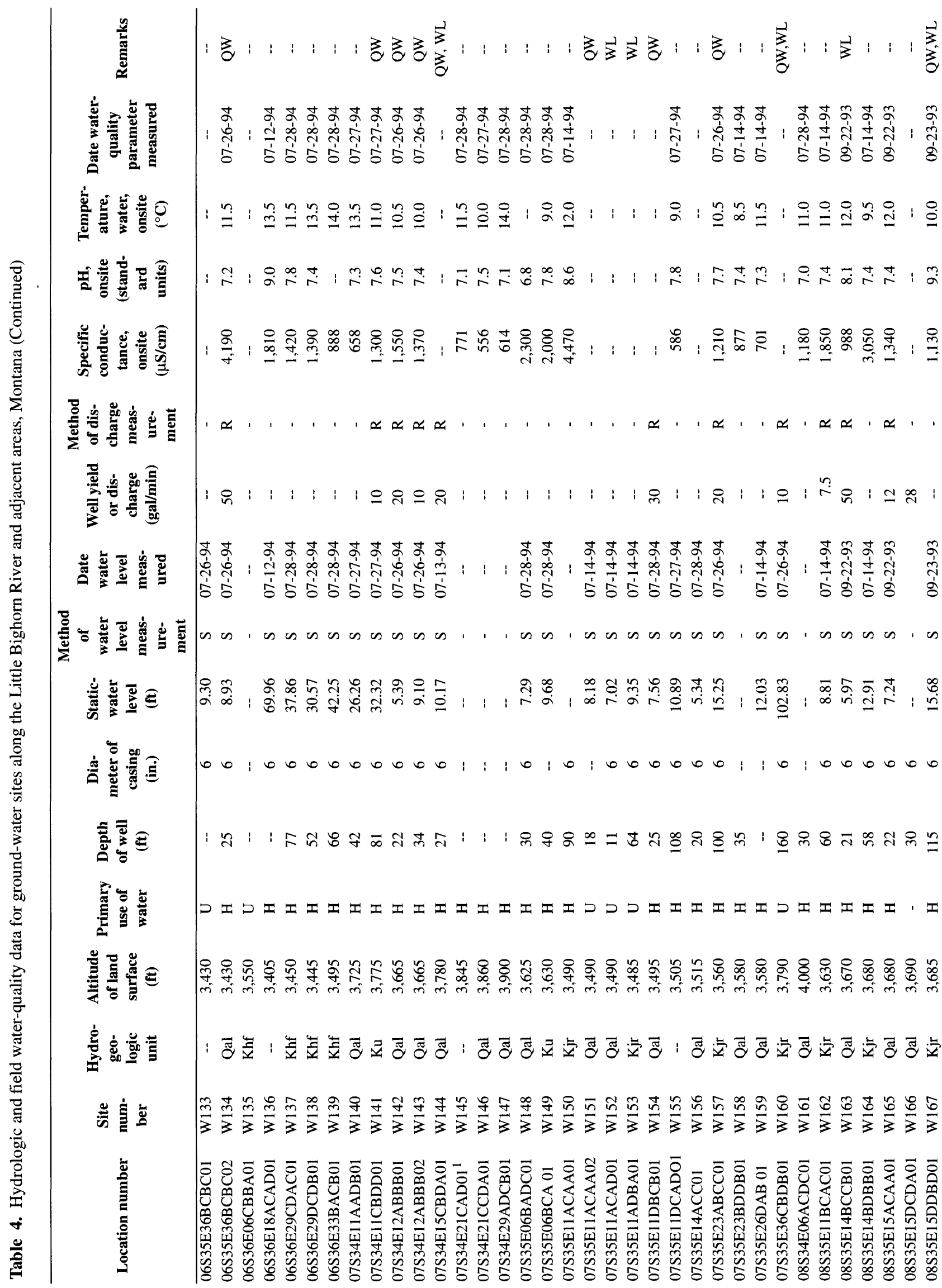




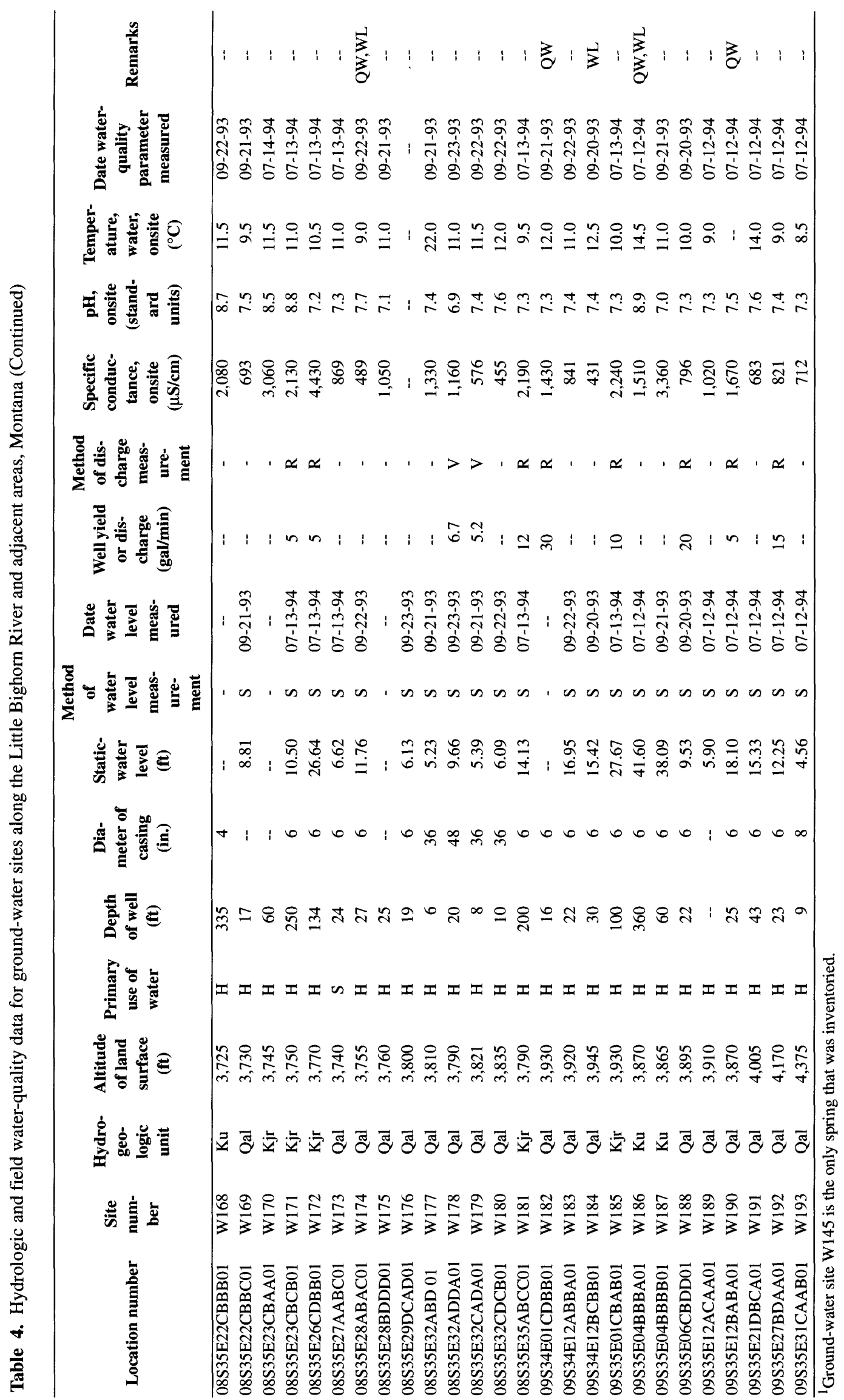


Table 5. Water-level data from selected wells along the Little Bighorn River and adjacent areas, Montana [Site number described in text. Abbreviations: $\mathrm{ft}$, feet below land surface]

\begin{tabular}{|c|c|c|c|c|c|c|c|}
\hline $\begin{array}{c}\text { Date of } \\
\text { water-level } \\
\text { measure- } \\
\text { ment }\end{array}$ & $\begin{array}{c}\text { Static- } \\
\text { water level, } \\
\text { in } \mathrm{ft}\end{array}$ & $\begin{array}{c}\text { Date of } \\
\text { water-level } \\
\text { measure- } \\
\text { ment }\end{array}$ & $\begin{array}{l}\text { Static- } \\
\text { water level, } \\
\text { in } \mathrm{ft}\end{array}$ & $\begin{array}{c}\text { Date of } \\
\text { water-level } \\
\text { measure- } \\
\text { ment }\end{array}$ & $\begin{array}{l}\text { Static- } \\
\text { water level, } \\
\text { in } \mathrm{ft}\end{array}$ & $\begin{array}{c}\text { Date of } \\
\text { water-level } \\
\text { measure- } \\
\text { ment }\end{array}$ & $\begin{array}{l}\text { Static- } \\
\text { water level, } \\
\text { in } \mathrm{ft}\end{array}$ \\
\hline $09-21-94$ & 17.80 & $06-28-94$ & 10.66 & $06-23-94$ & 16.01 & $09-21-94$ & 12.90 \\
\hline $10-17-94$ & 15.93 & $10-17-94$ & 10.55 & $09-20-94$ & 16.01 & $10-17-94$ & 12.60 \\
\hline $11-18-94$ & 14.36 & $11-18-94$ & 10.61 & $10-17-94$ & 16.16 & $11-18-94$ & 12.46 \\
\hline $02-07-95$ & 17.37 & $02-07-95$ & 9.54 & $01-10-95$ & 16.70 & $02-07-95$ & 12.27 \\
\hline 03-14-95 & 17.39 & $03-14-95$ & 9.42 & $02-07-95$ & 15.84 & $03-15-95$ & 11.86 \\
\hline $04-12-95$ & 17.28 & $04-12-95$ & 8.59 & $03-15-95$ & 15.57 & $04-12-95$ & 10.22 \\
\hline 05-09-95 & 17.41 & $04-28-95$ & 8.64 & $04-12-95$ & 14.61 & $05-09-95$ & 10.81 \\
\hline $06-07-95$ & 15.98 & 05-09-95 & 8.71 & $04-28-95$ & 14.49 & $05-24-95$ & 10.00 \\
\hline $06-21-95$ & 15.65 & $05-24-95$ & 9.55 & $05-09-95$ & 13.91 & $06-07-95$ & 10.76 \\
\hline \multirow{6}{*}{$08-22-95$} & & $08-22-95$ & 10.69 & $07-18-95$ & 15.02 & $08-22-95$ & 11.87 \\
\hline & & 09-19-95 & 11.00 & $08-10-95$ & 16.11 & $09-19-95$ & 12.02 \\
\hline & & $10-10-95$ & 10.80 & $08-22-95$ & 16.05 & $10-10-95$ & 11.89 \\
\hline & & $10-30-95$ & 10.65 & $09-19-95$ & 15.87 & $10-30-95$ & 12.09 \\
\hline & & & & $10-10-95$ & 15.65 & & \\
\hline & & & & $10-30-95$ & 15.98 & & \\
\hline
\end{tabular}

\begin{tabular}{|c|c|c|c|c|c|c|c|}
\hline $\begin{array}{c}\text { Date of } \\
\text { water-level } \\
\text { measure- } \\
\text { ment }\end{array}$ & $\begin{array}{c}\text { Static- } \\
\text { water level, } \\
\text { in } \mathrm{ft}\end{array}$ & $\begin{array}{c}\text { Date of } \\
\text { water-level } \\
\text { measure- } \\
\text { ment }\end{array}$ & $\begin{array}{c}\text { Static- } \\
\text { water level, } \\
\text { in } \mathrm{ft}\end{array}$ & $\begin{array}{c}\text { Date of } \\
\text { water-level } \\
\text { measure- } \\
\text { ment }\end{array}$ & $\begin{array}{c}\text { Static- } \\
\text { water level, } \\
\text { in } \mathbf{f t}\end{array}$ & $\begin{array}{c}\text { Date of } \\
\text { water-level } \\
\text { measure- } \\
\text { ment }\end{array}$ & $\begin{array}{c}\text { Static- } \\
\text { water level, } \\
\text { in } \mathrm{ft}\end{array}$ \\
\hline $06-27-94$ & 6.29 & $06-26-94$ & 16.43 & $06-27-94$ & 11.31 & $10-26-77$ & 126.20 \\
\hline $09-21-94$ & 6.66 & $09-21-94$ & 16.07 & $09-21-94$ & 11.56 & $04-12-78$ & 128.50 \\
\hline $10-17-94$ & 6.05 & $10-17-94$ & 15.88 & $10-17-94$ & 11.56 & $06-05-78$ & 85.76 \\
\hline $01-10-95$ & 6.13 & $01-10-95$ & 20.30 & $01-10-95$ & 13.73 & $01-08-79$ & 111.94 \\
\hline $02-07-95$ & 5.33 & $02-07-95$ & 21.76 & $02-07-95$ & 13.66 & $03-12-79$ & 119.47 \\
\hline 03-14-95 & 5.55 & $03-15-95$ & 18.58 & $03-15-95$ & 13.30 & $06-04-79$ & 80.56 \\
\hline $04-12-95$ & 5.47 & $04-12-95$ & 19.37 & $04-12-95$ & 13.40 & $09-13-79$ & 72.53 \\
\hline $04-28-95$ & 4.48 & $04-28-95$ & 15.94 & $04-28-95$ & 13.26 & $10-24-83$ & 147.40 \\
\hline $05-09-95$ & 5.06 & $05-09-95$ & 16.15 & $05-09-95$ & 13.20 & $12-06-84$ & 158.60 \\
\hline $07-18-95$ & 5.63 & $07-18-95$ & 16.61 & $07-18-95$ & 11.45 & $09-19-89$ & 109.69 \\
\hline $08-10-95$ & 6.31 & $08-10-95$ & 16.87 & $08-11-95$ & 10.50 & $09-27-90$ & 128.82 \\
\hline $08-22-95$ & 6.39 & $08-23-95$ & $\cdot 16.32$ & $08-22-95$ & 9.93 & $09-11-91$ & 137.75 \\
\hline $09-19-95$ & 6.43 & $09-19-95$ & 17.52 & $09-19-95$ & 11.51 & $08-20-92$ & 140.22 \\
\hline $10-10-95$ & 6.15 & $10-11-95$ & 16.70 & $10-11-95$ & 12.30 & $08-11-93$ & 134.35 \\
\hline $10-30-95$ & 6.08 & $10-30-95$ & 16.90 & & & $10-05-94$ & 146.33 \\
\hline & & & & & & $10-05-95$ & 125.60 \\
\hline
\end{tabular}


Table 5. Water-level data from selected wells along the Little Bighorn River and adjacent areas, Montana (Continued)

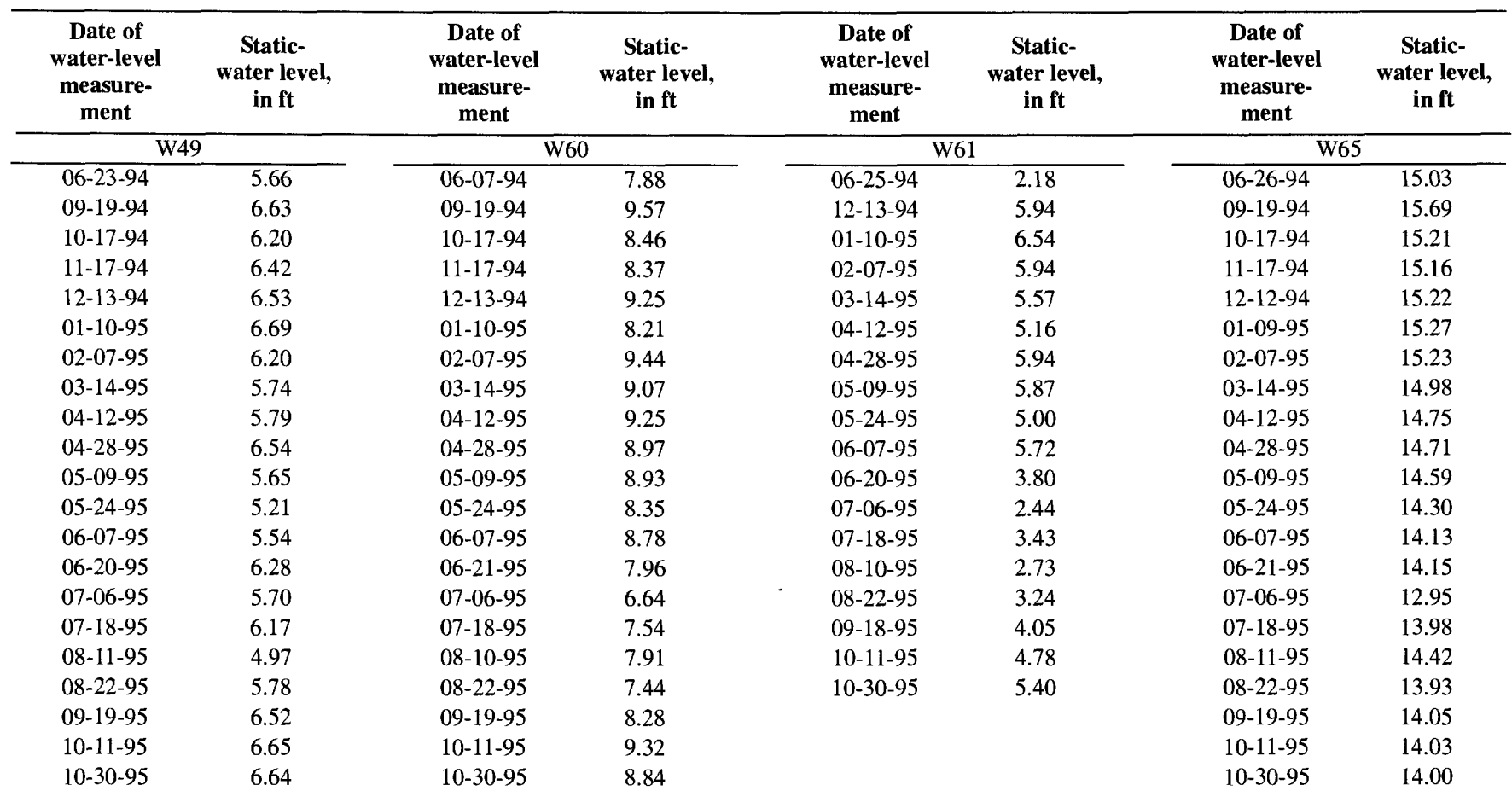

\begin{tabular}{|c|c|c|c|c|c|c|c|}
\hline $\begin{array}{c}\text { Date of } \\
\text { water-level } \\
\text { measure- } \\
\text { ment }\end{array}$ & $\begin{array}{c}\text { Static- } \\
\text { water level, } \\
\text { in } \mathbf{f t}\end{array}$ & $\begin{array}{c}\text { Date of } \\
\text { water-level } \\
\text { measure- } \\
\text { ment }\end{array}$ & $\begin{array}{c}\text { Static- } \\
\text { water level, } \\
\text { in } \mathrm{ft}\end{array}$ & $\begin{array}{c}\text { Date of } \\
\text { water-level } \\
\text { measure- } \\
\text { ment }\end{array}$ & $\begin{array}{c}\text { Static- } \\
\text { water level, } \\
\text { in } \mathrm{ft}\end{array}$ & $\begin{array}{c}\text { Date of } \\
\text { water-level } \\
\text { measure- } \\
\text { ment }\end{array}$ & $\begin{array}{c}\text { Static- } \\
\text { water level, } \\
\text { in } \mathrm{ft}\end{array}$ \\
\hline \multicolumn{2}{|c|}{ W67 } & \multicolumn{2}{|c|}{ W68 } & \multicolumn{2}{|c|}{ W76 } & \multicolumn{2}{|c|}{ W79 } \\
\hline $06-07-94$ & 21.10 & $06-07-94$ & 17.90 & $06-06-94$ & 12.17 & $06-07-94$ & 12.86 \\
\hline $09-19-94$ & 20.75 & 09-19-94 & 17.74 & $06-26-94$ & 12.32 & $09-19-94$ & 14.40 \\
\hline $10-17-94$ & 20.08 & $10-17-94$ & 17.35 & $09-19-94$ & 14.55 & $10-18-94$ & 14.01 \\
\hline $01-09-95$ & 20.05 & $01-09-95$ & 17.61 & $12-12-94$ & 13.29 & $01-09-95$ & 13.90 \\
\hline $02-07-95$ & 20.11 & $02-07-95$ & 17.66 & $01-09-95$ & 13.10 & $02-06-95$ & 13.30 \\
\hline $03-14-95$ & 20.62 & $03-14-95$ & 17.62 & $02-06-95$ & 12.40 & $03-14-95$ & 13.77 \\
\hline $04-12-95$ & 19.76 & $04-12-95$ & 17.49 & $03-14-95$ & 12.22 & $04-12-95$ & 13.67 \\
\hline $05-09-95$ & 19.78 & 05-09-95 & 17.47 & $04-12-95$ & 12.16 & $05-09-95$ & 13.19 \\
\hline $06-07-95$ & 19.67 & $06-07-95$ & 16.88 & $05-09-95$ & 12.08 & $06-07-95$ & 12.30 \\
\hline $09-19-95$ & 19.45 & $09-19-95$ & 16.73 & & & 09-09-95 & 13.82 \\
\hline $10-11-95$ & 19.37 & $10-11-95$ & 16.58 & & & $10-11-95$ & 13.95 \\
\hline $10-30-95$ & 19.27 & $10-30-95$ & 16.58 & & & $10-30-95$ & 13.80 \\
\hline
\end{tabular}


Table 5. Water-level data from selected wells along the Little Bighorn River and adjacent areas, Montana (Continued)

\begin{tabular}{|c|c|c|c|c|c|c|c|}
\hline $\begin{array}{c}\text { Date of } \\
\text { water-level } \\
\text { measure- } \\
\text { ment }\end{array}$ & $\begin{array}{c}\text { Static- } \\
\text { water level, } \\
\text { in } \mathbf{f t}\end{array}$ & $\begin{array}{c}\text { Date of } \\
\text { water-level } \\
\text { measure- } \\
\text { ment }\end{array}$ & $\begin{array}{c}\text { Static- } \\
\text { water level, } \\
\text { in } \mathrm{ft}\end{array}$ & $\begin{array}{c}\text { Date of } \\
\text { water-level } \\
\text { measure- } \\
\text { ment }\end{array}$ & $\begin{array}{c}\text { Static- } \\
\text { water level, } \\
\text { in } \mathrm{ft}\end{array}$ & $\begin{array}{c}\text { Date of } \\
\text { water-level } \\
\text { measure- } \\
\text { ment }\end{array}$ & $\begin{array}{l}\text { Static- } \\
\text { water level, } \\
\text { in } \mathrm{ft}\end{array}$ \\
\hline \multicolumn{2}{|c|}{ W90 } & \multicolumn{2}{|c|}{ W102 } & \multicolumn{2}{|c|}{ W110 } & \multicolumn{2}{|c|}{ W122 } \\
\hline $03-15-95$ & 6.47 & $07-12-94$ & 10.93 & $06-27-94$ & 40.10 & $07-26-94$ & 15.55 \\
\hline $04-12-95$ & 6.35 & $09-19-94$ & 11.01 & 09-19-94 & 34.26 & $09-19-94$ & 16.28 \\
\hline $04-28-95$ & 6.23 & $10-18-94$ & 10.53 & $10-18-94$ & 35.97 & $10-18-94$ & 16.16 \\
\hline $05-09-95$ & 6.51 & $11-17-94$ & 10.25 & $11-17-94$ & 37.26 & $11-17-94$ & 16.95 \\
\hline $05-24-95$ & 6.32 & $12-12-94$ & 10.09 & $12-12-94$ & 38.80 & $12-12-94$ & 16.00 \\
\hline $06-07-95$ & 6.74 & $01-09-95$ & 10.08 & $01-09-95$ & 40.23 & $01-09-95$ & 16.47 \\
\hline $06-20-95$ & 7.59 & $02-06-95$ & 9.61 & $02-06-95$ & 41.40 & $02-06-95$ & 15.92 \\
\hline $07-06-95$ & 9.18 & $03-14-95$ & 9.62 & 03-14-95 & 42.34 & $03-14-95$ & 14.78 \\
\hline $07-17-95$ & 8.14 & $04-12-95$ & 9.54 & $04-12-95$ & 41.42 & $04-12-95$ & 15.10 \\
\hline $08-11-95$ & 8.00 & $04-28-95$ & 9.47 & $04-28-95$ & 42.30 & $05-09-95$ & 14.86 \\
\hline $08-23-95$ & 7.90 & $05-09-95$ & 9.41 & 05-09-95 & 42.53 & $06-07-95$ & 15.15 \\
\hline 09-19-95 & 8.00 & $05-24-95$ & 9.05 & $05-24-95$ & 41.93 & $06-20-95$ & 14.19 \\
\hline $10-12-95$ & 7.67 & $06-07-95$ & 9.35 & $06-07-95$ & 39.64 & $07-17-95$ & 14.98 \\
\hline \multirow[t]{8}{*}{$10-30-95$} & 7.42 & $06-20-95$ & 9.56 & $06-20-95$ & 41.97 & $08-11-95$ & 15.95 \\
\hline & & $07-06-95$ & 9.88 & $07-06-95$ & 42.00 & $08-23-95$ & 15.50 \\
\hline & & $07-17-95$ & 9.93 & $07-17-95$ & 42.48 & $09-18-95$ & 15.85 \\
\hline & & $08-11-95$ & 9.75 & $08-11-95$ & 40.30 & $10-11-95$ & 15.66 \\
\hline & & $08-23-95$ & 10.29 & $08-23-95$ & 35.62 & $10-30-95$ & 15.62 \\
\hline & & $09-18-95$ & 9.99 & $09-19-95$ & 31.15 & & \\
\hline & & $10-11-95$ & 9.74 & $10-11-95$ & 31.45 & & \\
\hline & & $10-30-95$ & 9.62 & $10-30-95$ & 33.68 & & \\
\hline
\end{tabular}

\begin{tabular}{|c|c|c|c|c|c|c|c|}
\hline $\begin{array}{c}\text { Date of } \\
\text { water-level } \\
\text { measure- } \\
\text { ment }\end{array}$ & $\begin{array}{c}\text { Static- } \\
\text { water level, } \\
\text { in } \mathrm{ft}\end{array}$ & $\begin{array}{c}\text { Date of } \\
\text { water-level } \\
\text { measure- } \\
\text { ment }\end{array}$ & $\begin{array}{c}\text { Static- } \\
\text { water level, } \\
\text { in } \mathrm{ft}\end{array}$ & $\begin{array}{c}\text { Date of } \\
\text { water-level } \\
\text { measure- } \\
\text { ment }\end{array}$ & $\begin{array}{c}\text { Static- } \\
\text { water level, } \\
\text { in } \mathrm{ft}\end{array}$ & $\begin{array}{c}\text { Date of } \\
\text { water-level } \\
\text { measure- } \\
\text { ment }\end{array}$ & $\begin{array}{c}\text { Static- } \\
\text { water level, } \\
\text { in } \mathrm{ft}\end{array}$ \\
\hline \multicolumn{2}{|c|}{ W125 } & \multicolumn{2}{|c|}{ W126 } & \multicolumn{2}{|c|}{ W131 } & \multicolumn{2}{|c|}{ W144 } \\
\hline $07-27-94$ & 8.38 & $07-14-94$ & 6.31 & $11-17-94$ & 13.00 & $07-13-94$ & 10.17 \\
\hline $10-19-94$ & 8.17 & $09-20-94$ & 13.57 & $12-12-94$ & 12.77 & $09-19-94$ & 10.82 \\
\hline $11-17-94$ & 8.22 & $10-18-94$ & 16.16 & $01-09-95$ & 12.80 & $10-18-94$ & 10.63 \\
\hline $12-12-94$ & 8.13 & $11-17-94$ & 15.71 & $02-06-95$ & 11.96 & $11-17-94$ & 10.82 \\
\hline 01-09-95 & 7.87 & $12-12-94$ & 15.34 & 03-14-95 & 11.88 & $12-12-94$ & 10.59 \\
\hline $02-06-95$ & 7.66 & $01-09-95$ & 13.70 & $04-12-95$ & 11.53 & $01-09-95$ & 10.72 \\
\hline $03-14-95$ & 7.69 & $02-06-95$ & 13.37 & $04-28-95$ & 11.32 & $02-06-95$ & 10.56 \\
\hline $04-12-95$ & 7.73 & 03-14-95 & 14.57 & $05-09-95$ & 11.74 & 03-14-95 & 10.55 \\
\hline $04-28-95$ & 7.75 & $04-12-95$ & 14.31 & $05-24-95$ & 8.90 & $04-12-95$ & 10.60 \\
\hline $05-09-95$ & 6.79 & $04-28-95$ & 14.74 & $06-07-95$ & 9.19 & $05-09-95$ & 9.82 \\
\hline $05-24-95$ & 6.04 & $05-09-95$ & 13.29 & $06-20-95$ & 8.09 & $06-07-95$ & 9.15 \\
\hline $06-07-95$ & 5.87 & $05-24-95$ & 11.40 & $07-06-95$ & 9.10 & $06-20-95$ & 9.16 \\
\hline $06-20-95$ & 5.65 & $06-07-95$ & 11.93 & $07-17-95$ & 9.59 & $07-17-95$ & 9.95 \\
\hline $07-06-95$ & 6.98 & $07-06-95$ & 12.61 & $08-11-95$ & 10.55 & $08-11-95$ & 10.32 \\
\hline $07-17-95$ & 7.46 & $07-17-95$ & 11.99 & $08-23-95$ & 10.98 & $08-23-95$ & 10.39 \\
\hline $08-11-95$ & 8.32 & $08-11-95$ & 7.75 & 09-18-95 & 11.78 & $09-18-95$ & 10.45 \\
\hline \multirow[t]{4}{*}{$08-23-95$} & 8.48 & $08-23-95$ & 8.51 & $10-11-95$ & 11.64 & $10-11-95$ & 10.55 \\
\hline & & 09-18-95 & 4.93 & $10-30-95$ & 11.77 & $10-30-95$ & 10.49 \\
\hline & & $10-11-95$ & 8.23 & & & & \\
\hline & & $10-30-95$ & 12.32 & & & & \\
\hline
\end{tabular}


Table 5. Water-level data from selected wells along the Little Bighorn River and adjacent areas, Montana (Continued)

\begin{tabular}{|c|c|c|c|c|c|c|c|}
\hline $\begin{array}{c}\text { Date of } \\
\text { water-level } \\
\text { measure- } \\
\text { ment }\end{array}$ & $\begin{array}{c}\text { Static- } \\
\text { water level, } \\
\text { in } \mathrm{ft}\end{array}$ & $\begin{array}{c}\text { Date of } \\
\text { water-level } \\
\text { measure- } \\
\text { ment }\end{array}$ & $\begin{array}{c}\text { Static- } \\
\text { water level, } \\
\text { in } \mathbf{f t}\end{array}$ & $\begin{array}{c}\text { Date of } \\
\text { water-level } \\
\text { measure- } \\
\text { ment }\end{array}$ & $\begin{array}{c}\text { Static- } \\
\text { water level, } \\
\text { in } \mathrm{ft}\end{array}$ & $\begin{array}{c}\text { Date of } \\
\text { water-level } \\
\text { measure- } \\
\text { ment }\end{array}$ & $\begin{array}{c}\text { Static- } \\
\text { water level, } \\
\text { in } \mathrm{ft}\end{array}$ \\
\hline $07-14-94$ & 7.02 & $07-14-94$ & 9.35 & $07-26-94$ & 102.83 & $07-27-94$ & 5.97 \\
\hline $09-21-94$ & 8.79 & $09-21-94$ & 10.52 & $09-20-94$ & 102.80 & $09-20-94$ & 6.16 \\
\hline $10-18-94$ & 8.33 & $10-18-94$ & 9.59 & $10-19-94$ & 103.05 & $10-19-94$ & 5.45 \\
\hline $01-09-95$ & 7.70 & $01-09-95$ & 8.97 & $01-09-95$ & 102.43 & $01-09-95$ & 4.83 \\
\hline $02-06-95$ & 7.19 & $02-06-95$ & 9.18 & $02-06-95$ & 102.82 & $02-06-95$ & 5.06 \\
\hline $03-14-95$ & 6.92 & $03-14-95$ & 8.93 & $03-14-95$ & 102.80 & $03-14-95$ & 4.99 \\
\hline $04-12-95$ & 6.48 & $04-12-95$ & 9.08 & $04-12-95$ & 102.72 & $04-12-95$ & 5.14 \\
\hline $05-09-95$ & 5.96 & $05-09-95$ & 8.57 & $05-09-95$ & 102.72 & $04-28-95$ & 4.98 \\
\hline $06-07-95$ & 3.95 & $06-07-95$ & 6.04 & $06-07-95$ & 102.67 & $05-09-95$ & 5.14 \\
\hline $09-18-95$ & 7.42 & $09-18-95$ & 9.49 & & & $08-22-95$ & 5.86 \\
\hline $10-11-95$ & 7.22 & $10-11-95$ & 9.35 & & & $09-18-95$ & 5.80 \\
\hline $10-30-95$ & 7.03 & $10-30-95$ & 9.24 & & & $10-11-95$ & 5.67 \\
\hline & & & & & & $10-30-95$ & 5.55 \\
\hline
\end{tabular}

\begin{tabular}{|c|c|c|c|c|c|c|c|}
\hline $\begin{array}{c}\text { Date of } \\
\text { water-level } \\
\text { measure- } \\
\text { ment }\end{array}$ & $\begin{array}{c}\text { Static- } \\
\text { water level, in } \\
\mathbf{f t}\end{array}$ & $\begin{array}{c}\text { Date of } \\
\text { water-level } \\
\text { measure- } \\
\text { ment }\end{array}$ & $\begin{array}{c}\text { Static- } \\
\text { water level, } \\
\text { in } \mathrm{ft}\end{array}$ & $\begin{array}{c}\text { Date of } \\
\text { water-level } \\
\text { measure- } \\
\text { ment }\end{array}$ & $\begin{array}{l}\text { Static- } \\
\text { water level, } \\
\text { in } \mathrm{ft}\end{array}$ & $\begin{array}{c}\text { Date of } \\
\text { water-level } \\
\text { measure- } \\
\text { ment }\end{array}$ & $\begin{array}{c}\text { Static- } \\
\text { water level, } \\
\text { in } \mathrm{ft}\end{array}$ \\
\hline \multicolumn{2}{|c|}{ W167 } & \multicolumn{2}{|c|}{ W174 } & \multicolumn{2}{|c|}{ W184 } & \multicolumn{2}{|c|}{ W186 } \\
\hline $09-23-93$ & 15.68 & $09-22-93$ & 11.76 & $09-20-93$ & 17.40 & $07-12-94$ & 41.60 \\
\hline $07-15-94$ & 14.85 & $07-15-94$ & 11.44 & $07-15-94$ & 15.42 & $10-18-94$ & 44.35 \\
\hline $09-20-94$ & 15.20 & $09-20-94$ & 11.88 & $09-20-94$ & 15.87 & $11-17-94$ & 47.40 \\
\hline $10-18-94$ & 14.88 & $10-19-94$ & 11.51 & $10-18-94$ & 15.83 & $12-12-94$ & 48.15 \\
\hline $11-17-94$ & 15.12 & $11-17-94$ & 11.87 & $11-17-94$ & 16.04 & $01-09-95$ & 48.94 \\
\hline $12-12-94$ & 15.38 & $12-12-94$ & 11.59 & $12-12-94$ & 16.09 & $02-06-95$ & 56.72 \\
\hline 01-09-95 & 15.29 & $01-09-95$ & 11.23 & 01-09-95 & 15.71 & $03-14-95$ & 49.61 \\
\hline $02-06-95$ & 18.49 & $02-06-95$ & 11.92 & $02-06-95$ & 16.11 & $04-12-95$ & 49.91 \\
\hline $03-14-95$ & 15.10 & $03-14-95$ & 12.02 & $03-14-95$ & 16.18 & $05-09-95$ & 51.29 \\
\hline $04-12-95$ & 15.68 & $04-12-95$ & 11.85 & $04-12-95$ & 15.97 & $06-07-95$ & 49.03 \\
\hline $05-09-95$ & 15.09 & $05-09-95$ & 11.33 & $05-09-95$ & 12.86 & $06-20-95$ & 48.12 \\
\hline $06-07-95$ & 13.87 & $06-07-95$ & 8.73 & $06-07-95$ & 12.40 & $07-17-95$ & 45.45 \\
\hline $06-20-95$ & 14.60 & $06-20-95$ & 8.81 & $06-20-95$ & 13.11 & $08-11-95$ & 42.03 \\
\hline $07-17-95$ & 14.36 & $07-17-95$ & 10.34 & $07-17-95$ & 14.60 & $08-23-95$ & 44.65 \\
\hline $08-11-95$ & 16.56 & $08-11-95$ & 11.34 & $08-11-95$ & 15.25 & $09-19-95$ & 45.53 \\
\hline $08-23-95$ & 16.73 & $08-22-95$ & 11.52 & $08-23-95$ & 15.38 & $10-11-95$ & 45.16 \\
\hline $09-18-95$ & 15.40 & 09-18-95 & 11.45 & $09-18-95$ & 15.52 & & \\
\hline \multirow[t]{2}{*}{$10-11-95$} & 14.95 & $10-11-95$ & 11.50 & $10-11-95$ & 15.60 & & \\
\hline & & $10-30-95$ & 10.21 & $10-30-95$ & 15.73 & & \\
\hline
\end{tabular}




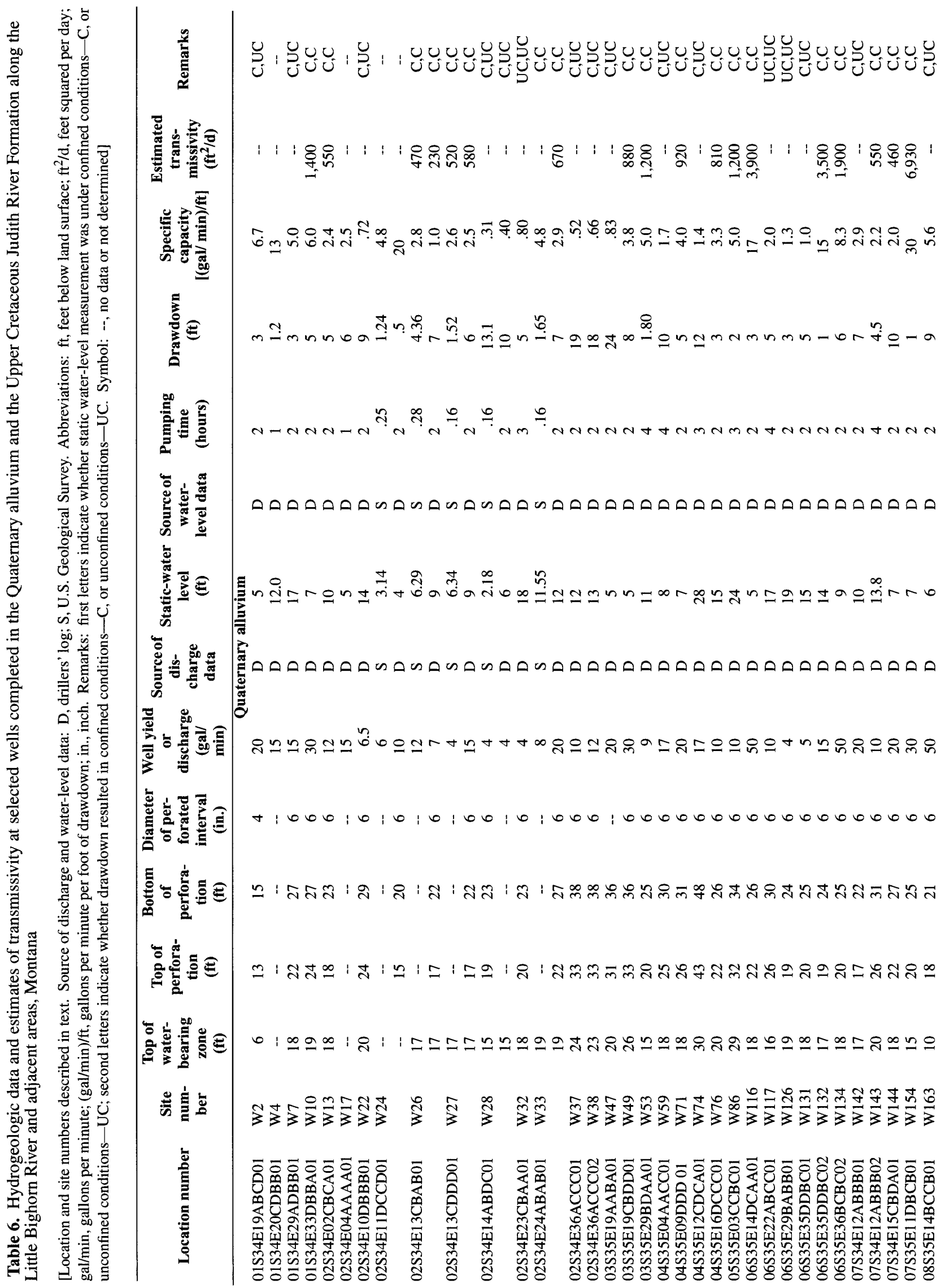




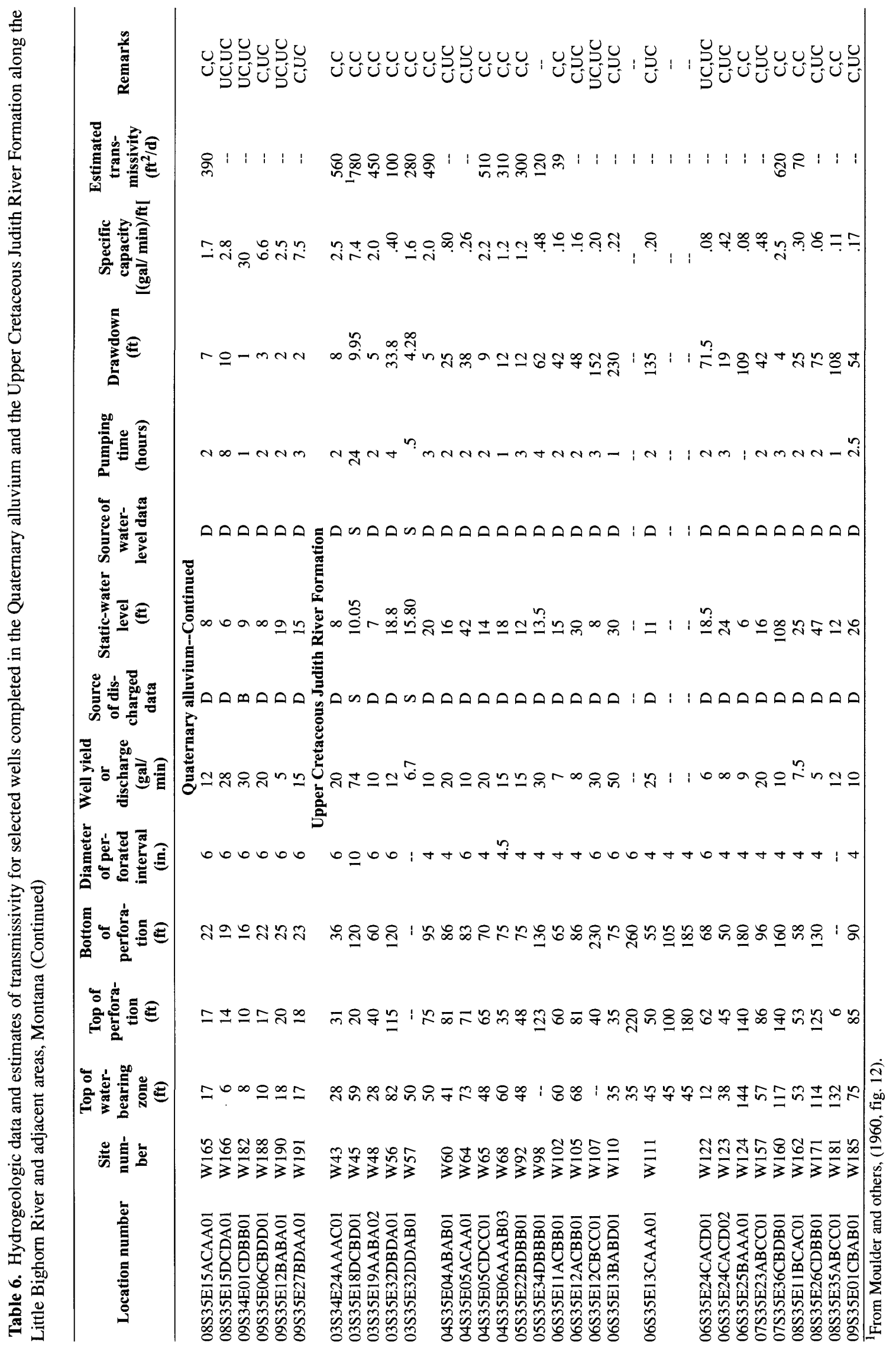




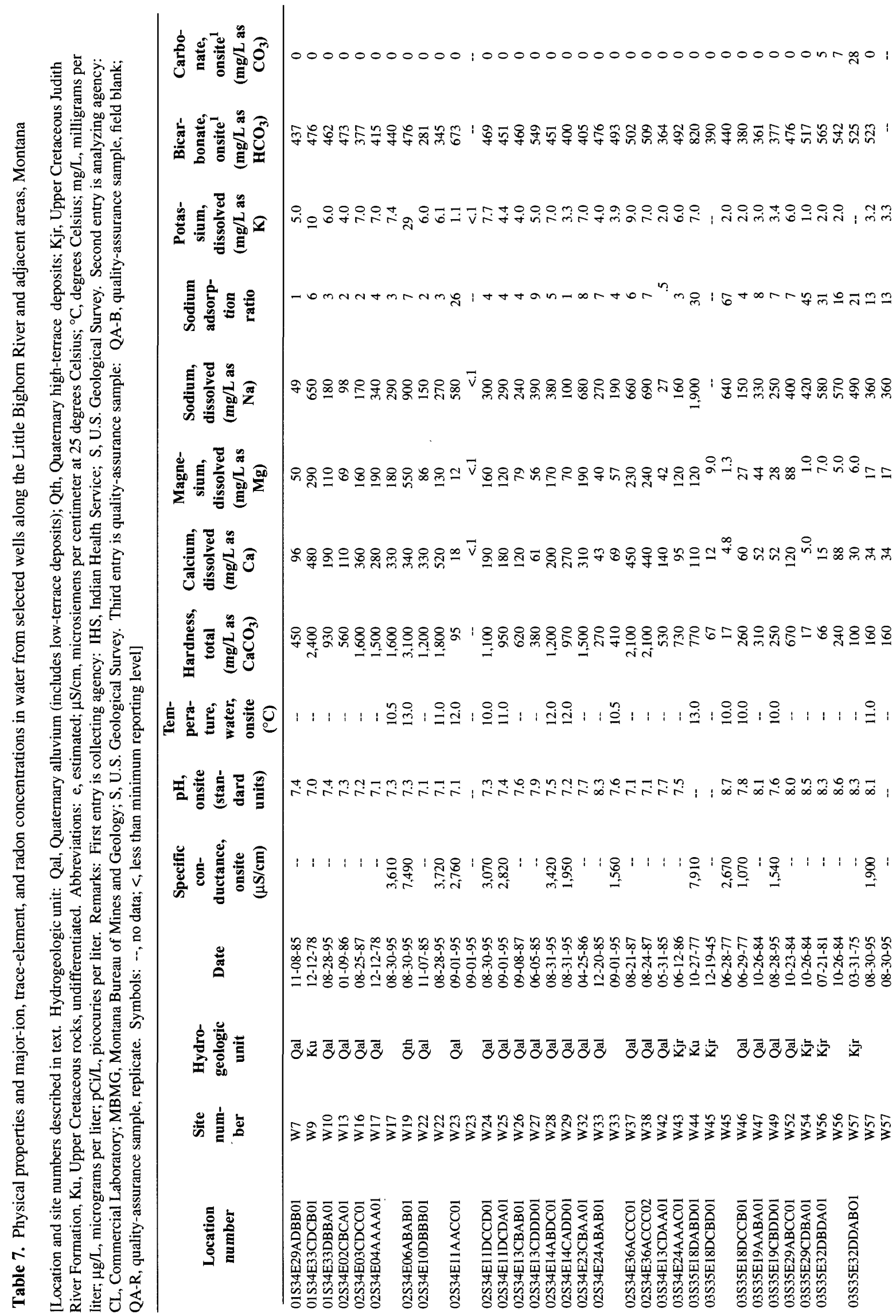




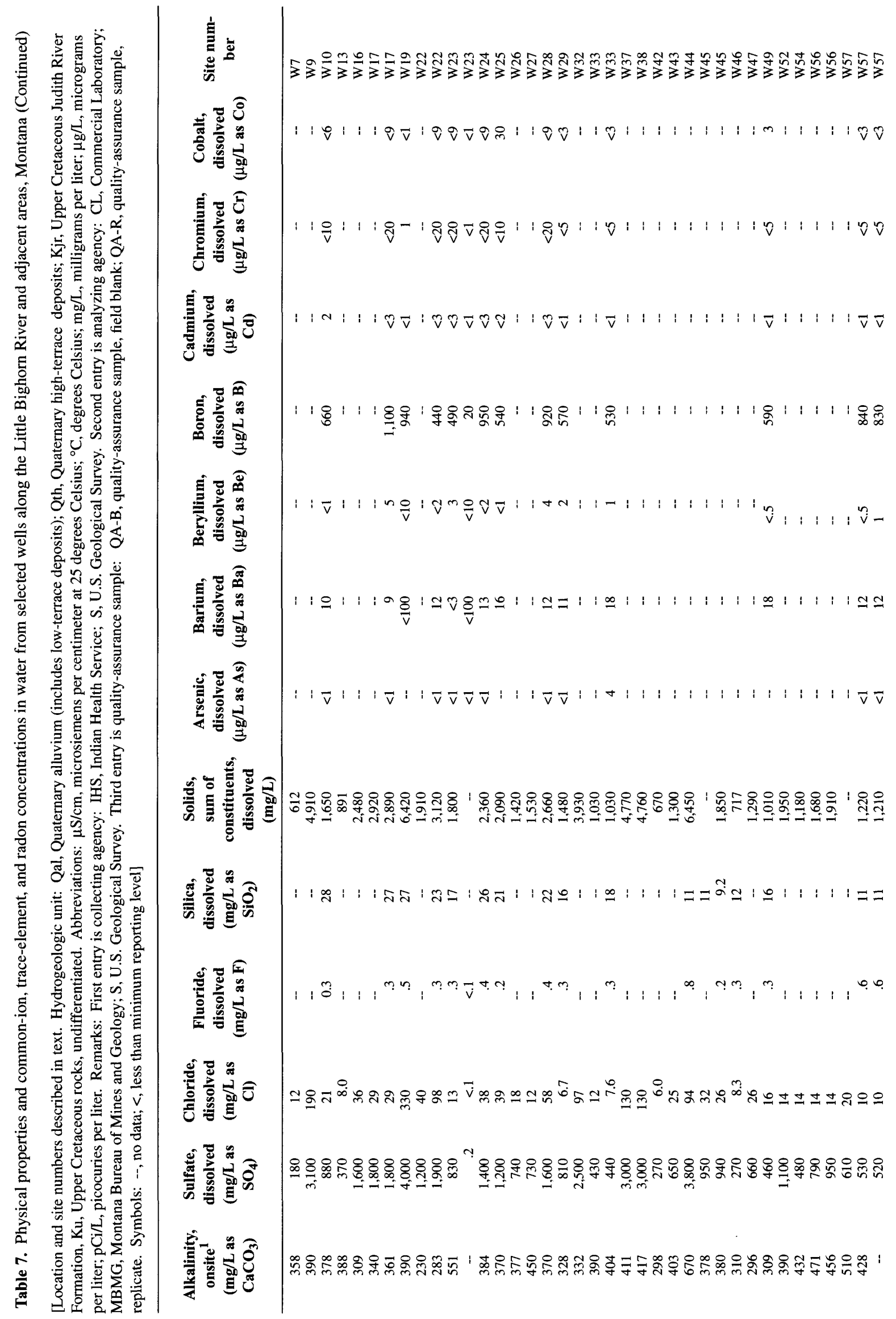




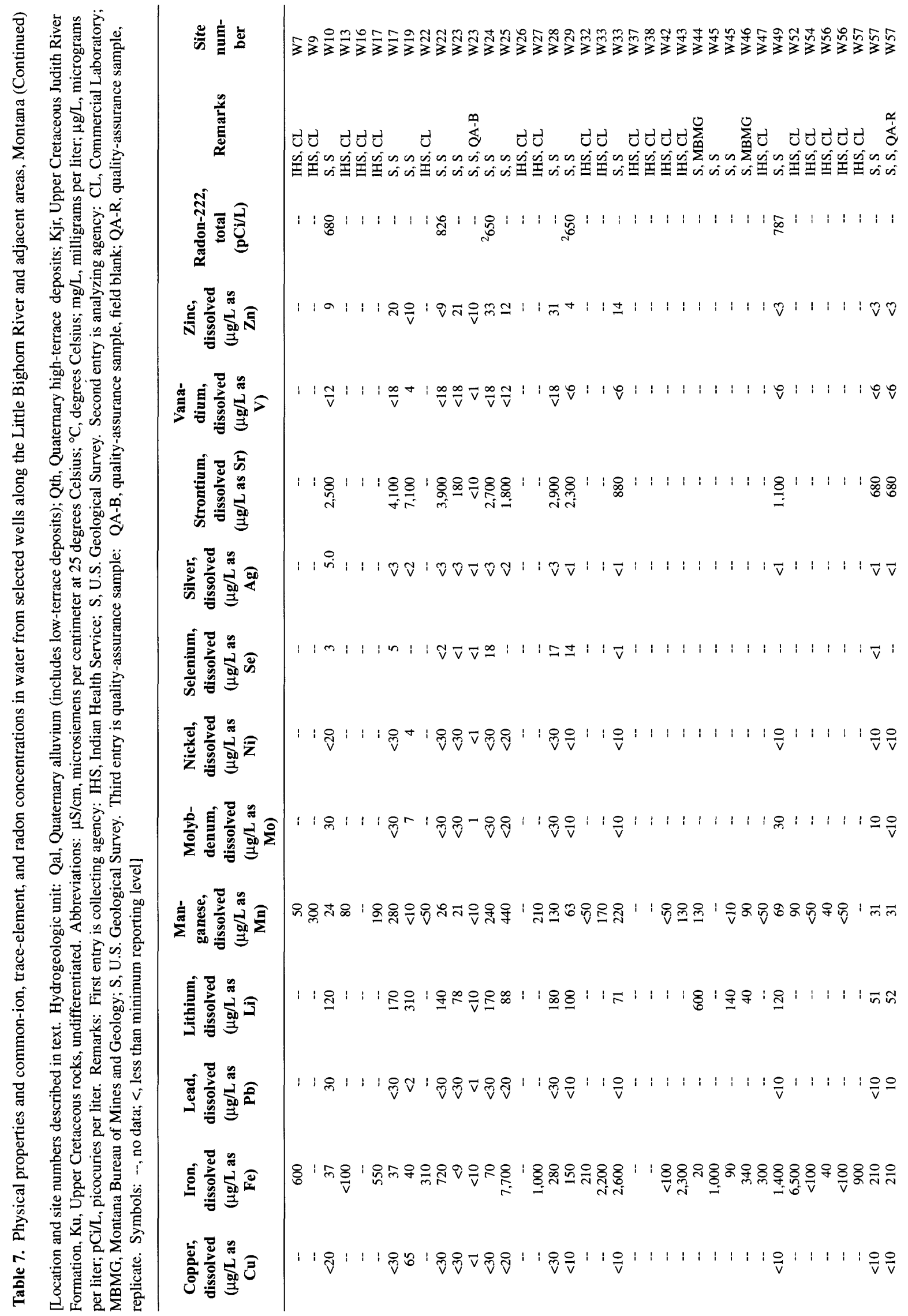




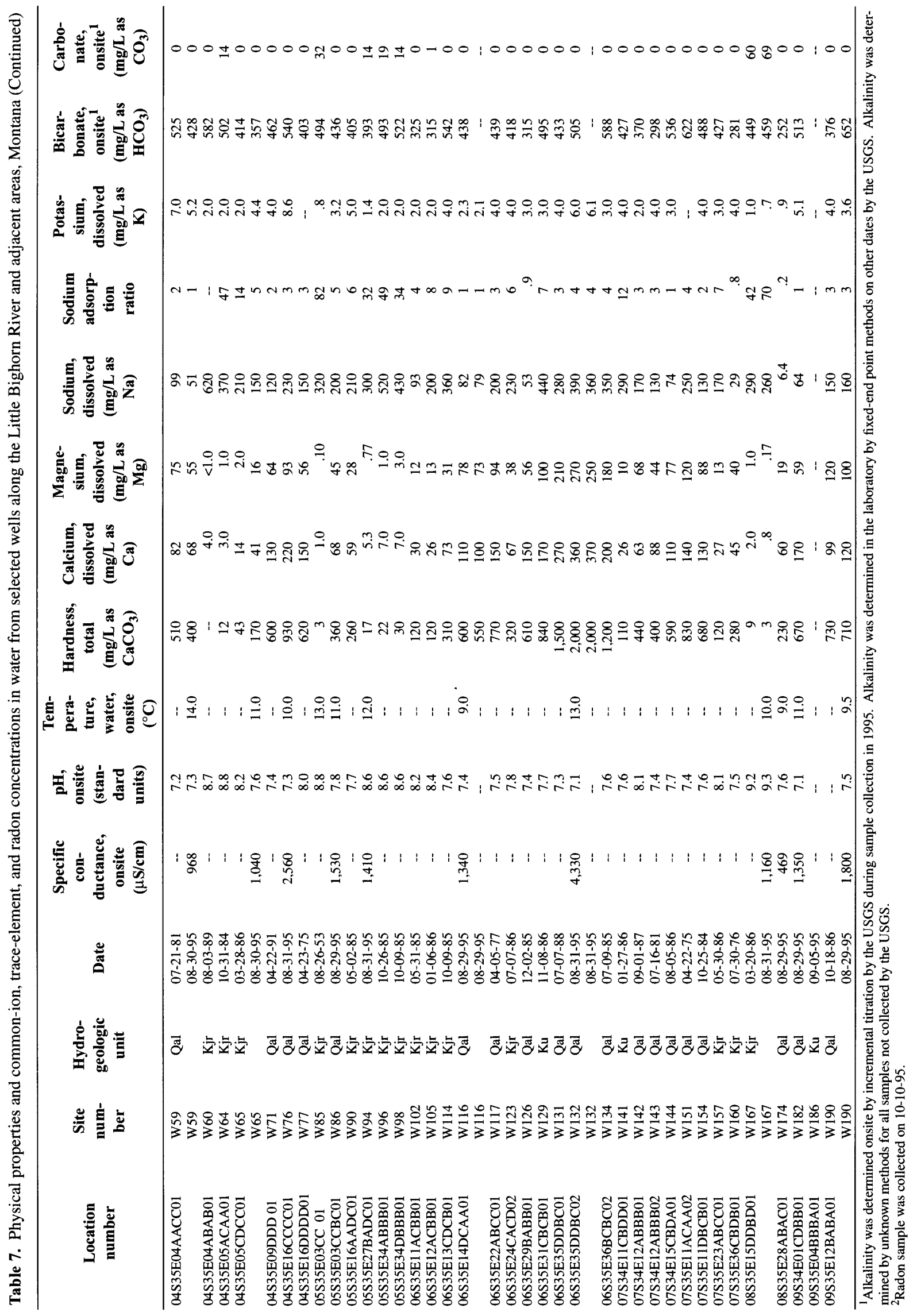




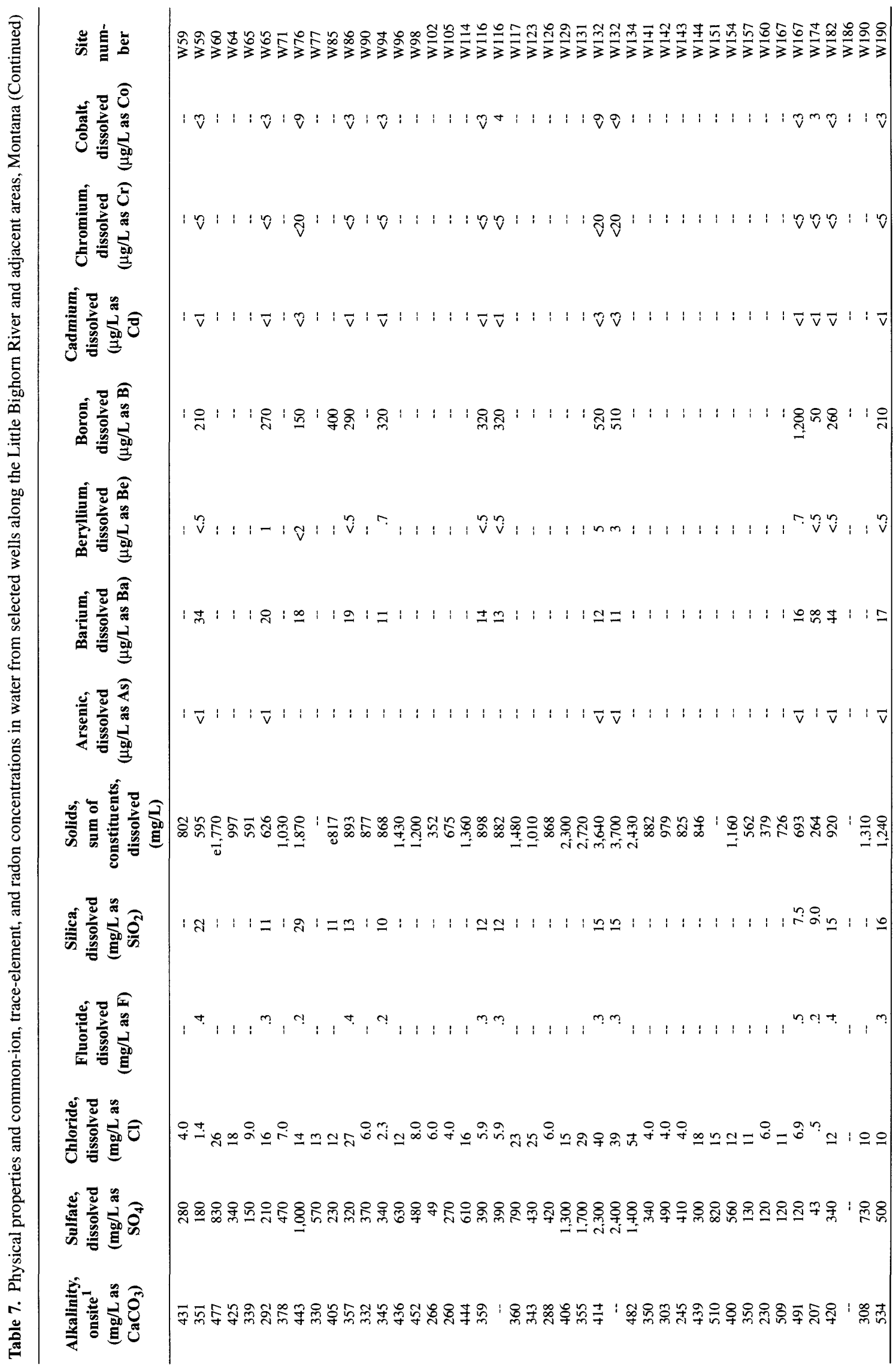




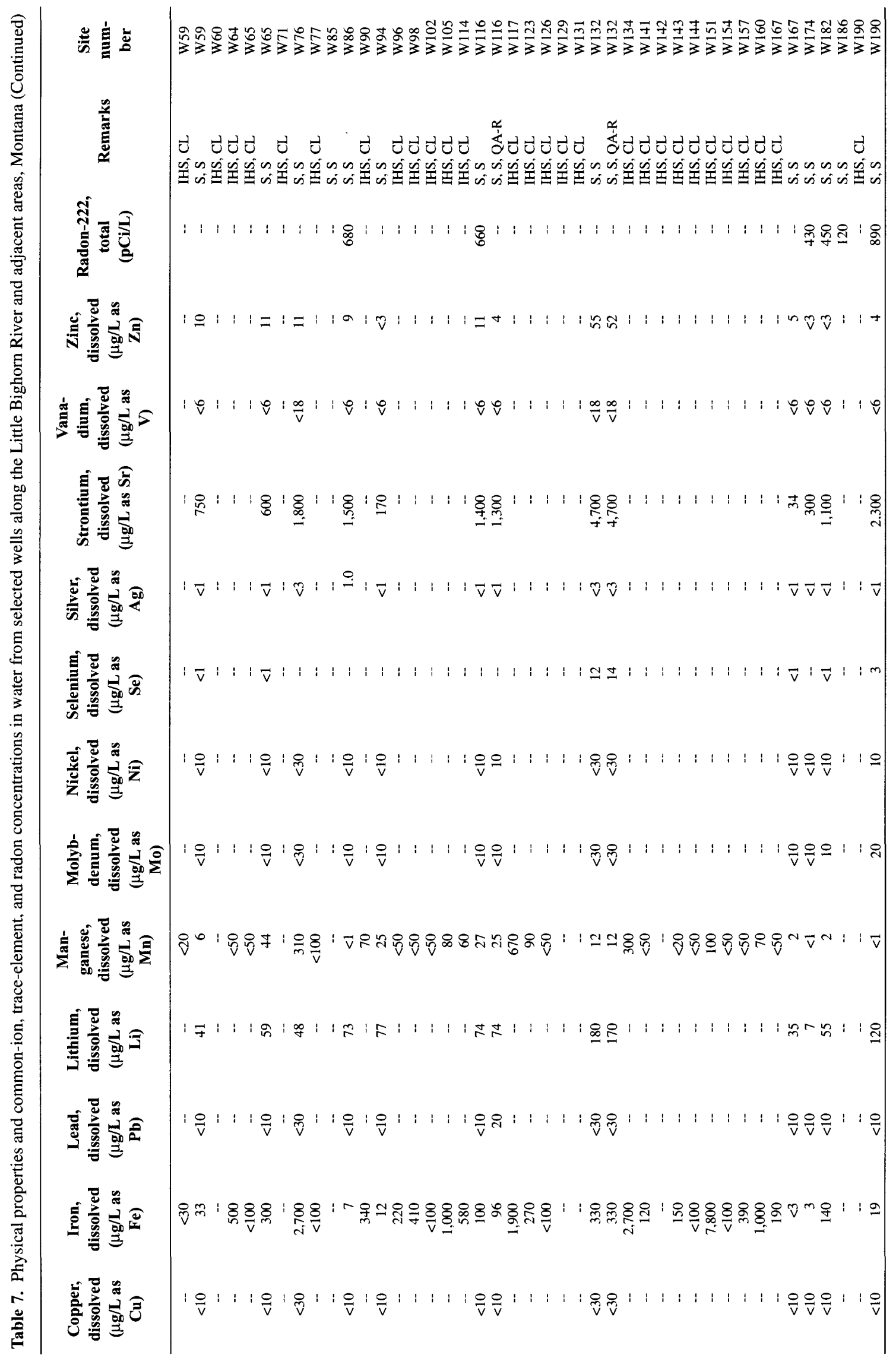


